\title{
Personal Property Servitudes
}

\author{
Glen O. Robinson†
}

This Article explores the lawfulness of servitudes on personal property in both common law and intellectual property regimes. The common law has from ancient times recognized the general right of owners of real property to burden land with restrictions on userestrictions that "run with the land"-subject to various conditions and limitations. It has been more ambivalent about similar restrictions on personal property. Why? That question was broached seventy-five years ago by Zechariah Chafee, though he never fully answered it. Today, the question has acquired a new importance because of the pervasive use of computer software licensing restrictions that, for all practical purposes, can be regarded as a form of property servitude. Software licensing restrictions implicate specialized rules of intellectual property, such as the first sale doctrine. However, those rules are basically derived from common law policies (most notably policies against restraints on alienation and restraints of trade), so the question about the legality of such restrictions is essentially no different for intellectual property from that question in the context of personal property at common law. This Article argues that the traditional hostility to use and resale restraints on personal property is misguided in both the common law and intellectual property contexts. While there may be legitimate reasons for limiting an owner's right to impose post-transfer restrictions on use and resale, those reasons are more exceptional than has been commonly assumed. Moreover, in the new digital world where servitude-type restrictions can be engineered into the architecture of the property itself, public policy restrictions on contractual "servitudes" may prove to be ineffectual, creating a new reason to take a fresh look at old conceptions of personal property servitudes.

\section{INTRODUCTION}

Anglo-American property law has recognized contractually created servitudes on real property for over four centuries. The power to

$\dagger$ David A. and Mary Harrison Distinguished Professor of Law, University of Virginia. Thanks to Tom Nachbar, Ed Kitch, Clarisa Long, Lillian BeVier, Greg Alexander, and Tim Wu for helpful comments and continuous conversation over the too-long gestation of this project; to participants in legal studies workshops at the University of Virginia and Vanderbilt; and to Wes Williams and Alison Swap for excellent research assistance.

1 Covenants that run with the land were first recognized at common law in Spencer's Case, 
impose restrictions on the use of land is an incident of the power to transfer, one of the conventional attributes of ownership. Of course, this is an oversimplification, for there are numerous restraints on how owners dispose of their property. Property owners cannot, for instance, impose restraints that offend public policy by imposing racially restrictive covenants, ${ }^{2}$ restraining alienation, ${ }^{3}$ or creating restraints of trade. ${ }^{4}$ However, even after accounting for all such public policy constraints, the power of property owners to place post-transfer limitations on the use of property remains robust and provides the foundation for an entire jurisprudence of servitude law.

Or, at least so long as the property being transferred is real property. What about personal property? Seventy-five years ago Zechariah Chafee puzzled over the absence of any comparable power over the use of chattels. Why, Chafee asked, has the law not generally recognized a power to create servitudes for personal property comparable to that recognized for real property? ? $^{5}$ Chafee understood that there were relevant differences between real property and chattels that might call for special limitations on power over the latter-for example, antitrust issues or special limitations on intellectual property rights. ${ }^{6}$ But, conceding that such special objections might narrowly confine the realm of legitimate use for chattel servitudes, Chafee concluded that the "complexities and variety of modern business may

77 Eng Rep 72 (QB 1583). Originally confined to covenants binding only on parties who were in privity of estate, servitudes became enforceable in equity with Tulkv Moxhay, 41 Eng Rep 1143 (Ch 1848). Although it is doctrinally conventional to identify running covenants and equitable servitudes as distinctive forms of property, for all practical purposes the latter has swallowed up the former, and I shall treat them as the same thing.

2 Shelley $v$ Kraemer, 334 US 1 (1948) (invalidating a restrictive covenant that prevented the occupation of residential land by non-Caucasians for a period of fifty years).

3 See, for example, Restatement (Second) of Property (Donative Transfers) \$\$ 3-4 (1981) (explicating the rule against direct restraints on alienation in real property).

4 See, for example, Dr. Miles Medical Co v John D. Park \& Sons Co, 220 US 373 (1911) (holding a resale price condition to be a restraint of trade).

5 Zechariah Chafee, Jr., Equitable Servitudes on Chattels, 41 Harv L Rev 945 (1928). Why Chafee focused on the model of equitable servitudes as opposed to real covenants running at law is not clear; perhaps Chafee assumed the privity of estate requirement for running covenants was sufficient to answer the question of why chattels, to which the concept of "estate" is not easily applied, could not be fit within Spencer's Case. That doctrinal point is an empty formalism, however, for exactly the reason that the current distinction between real covenants and equitable servitudes is an empty formalism. In the modern age there is no reason to distinguish between covenants that run at law and those that run in equity in either real property or chattels. If there is no other reason to distinguish restrictions on personal and real property, the antiquated concept of privity of estate should not be a basis for such a distinction. Nevertheless, as we shall see, the question of whether personal property can be made subject to durable restrictions on use or sale is invariably treated as a matter of applying the law of equitable servitudes rather than running covenants. It probably does not matter; in virtually all cases the remedy sought is an injunction against violating the restrictions and hence falls within the ken of equitable servitude doctrine.

6 Id at $987-1007$. 
eventually present opportunities for restrictions on personalty which are free from the disadvantages of restraint of trade."7

Nearly three decades after his original speculations Chafee entertained second thoughts about the matter. ${ }^{8}$ The occasion for the second thoughts was a state case enforcing an equitable servitude on a jukebox. Plaintiff had entered into a lease agreement with the owner of a luncheonette for the installation and servicing of a jukebox. The agreement required a rent payment of 60 percent of the jukebox receipts, prohibited removal of the jukebox, required it to be operated, and prohibited installation or operation of any similar equipment during the period of the lease (fourteen and a half years). A final clause of the agreement made it binding on the parties' successors and assigns. A year into the lease the lessee sold the luncheonette to defendant. Although defendant knew of the prior agreement, he claimed not to know that the rent called for 60 percent of the receipts - apparently a higher percentage than that demanded by plaintiff's competitors. When defendant learned of the rental amount he told plaintiff to remove the jukebox or he would remove it at plaintiff's expense. Plaintiff then sued to enjoin removal and to specifically enforce the agreement. Reversing a trial court judgment, the New Hampshire Supreme Court found that the agreement was binding on the defendant and could be specifically enforced as an equitable servitude.

Chafee was bothered by the fact that the court gave no attention to troublesome questions of public policy about enforcement of such restrictions, such as whether the business justifications for them outweighed the "grave possibilities of annoyance, inconvenience, and useless expenditure of money" that this type of equitable servitude could entail. ${ }^{10}$ Without committing to a clear answer to that question, he noted that the principal business purpose for such restraints turned out to be resale price fixing or tying," which were both illegal at the time he first wrote in 1928. Apart from such illegal purposes it now appeared to him that there might be too few business needs for such restrictions to make it worthwhile to recognize them generally."

Nearly a half century later, there is reason to entertain third thoughts on the matter despite the general disposition of courts and commentators to be content with Chafee's judgment. Indeed, the

Id at 1013.

8 Zechariah Chafee, Jr., The Music Goes Round and Round: Equitable Servitudes and Chattels, 69 Harv L Rev 1250 (1956).

9 Pratte $v$ Balatsos, 99 NH 430, 113 A2d 492 (1955).

10 Chafee, 69 Harv L Rev at 1258 (cited in note 8 ).

11 Id at $1254-55$.

12 Id at 1258. 
question of chattel servitudes has gained a new salience in light of recent developments in the field of intellectual property, where the now ubiquitous use of restrictive licensing agreements has created the functional equivalent of personal property servitudes. Because the most important contemporary occasion for considering personal property restrictions arises in the field of intellectual property, that special form of property rights will receive the lion's share of attention in this Article, but this should not obscure the fact that I am concerned about property rights in general, not simply intellectual property rights.

There are translation problems in moving from common law property to intellectual property. Common law property differs from intellectual property in a number of important respects, and it would be simplistic to disregard those differences. However, I shall argue that the same underlying policy considerations are relevant to both types of property rights.

I begin in Part I with a brief updating of Chafee's review of the older case law involving common law property. My purpose here is merely to establish that personal property servitudes, while exceptional, do still appear in the law and can serve legitimate purposes in commercial transactions just as Chafee originally surmised they might. Whether those commercial purposes are of much practical importance for conventional personal property remains an open question. Contractual restrictions on the distribution of goods are a common business strategy, enabling commercial vendors to control how their products are designed, priced, and marketed. Granted, in most cases this purpose can be served by contract without the necessity of making the contract "run with the goods" as a servitude. However, the choice of control instruments is a matter best left to the property owner and the market except in those relatively few cases where there is an overriding public policy against any restraint (of which more later).

In any event, the power to enforce servitude-like restrictions has become a significant practical issue in the domain of intellectual property, to which Part II shifts the discussion. In this property domain the question of resale and use restrictions primarily implicates the "first sale" or "exhaustion" doctrine that limits post-sale restrictions on the use and transfer of copyrighted, patented, or trademarked objects. ${ }^{13}$ My treatment in Part II is primarily historical and is confined to patent and copyright cases, since for my purposes the trademark context

13 As a matter of semantics, "first sale" is the label generally used in copyright and trademark cases, and "exhaustion" is the more common label for patent cases. This Article will use the formulation of "first sale" in all contexts. 
does not add anything important to the other contexts. The history suggests that the reasons for the doctrine are less clear than is often now assumed. Although the first sale doctrine today is often explained as a creature of public policy (most notably policies against restraints on alienation or restraints of trade), the early decisions suggest that it is simply a limit on the owner's rights to claim patent or copyright infringement, leaving open the possibility that an owner might impose restraints by contract. The latter possibility seems to defeat the argument that the doctrine derives from alienation or trade policies, which should be no less applicable to enforcement of contract rights than to intellectual property rights.

The extent to which one can contract around the first sale doctrine or other limitations imposed by copyright and patent laws is now hotly debated, particularly in the context of copyright where the ubiquitous use of licenses as a means of distributing copies of copyrighted software has been seen as a circumvention of the limitations on copyright protections. I argue that whether one should be able to contract around limitations on copyrighted or patented property should depend not on some formalistic distinction between contract rights and property rights, but on the policies at stake, and these policies require a closer examination than they have generally been given. In Part III, I undertake such an examination. I begin with the policy against restraints on alienation. It is a venerable part of the common law of property, as every law student learns. It also makes for a very flimsy argument against allowing such agreements. Use restraints are a routine feature of common law property transactions; that is what real property servitudes are all about. To the extent such restraints are valid for real property, they should be valid, pari passu, for personal property. Insofar as the first sale doctrine is grounded on this policy, I argue that such restraints in principle ought to be equally valid for intellectual property. Of course, intellectual property rights are specially limited in ways that common law property rights are not, but this is irrelevant to the argument about alienability, which derives from the common law, not from any distinctive concept of intellectual property.

Trade restraints are another matter, though here too the invocation of public policy is much too facile. Some use restraints do implicate antitrust law; for instance, the first sale doctrine first arose in the context of resale price restraints - an antitrust offense of long standing. In such cases forbidding the restriction as a matter of property law is harmless, but it is also unnecessary since antitrust policy provides a completely sufficient grounds for withholding legal enforcement of the restrictions and makes it separately actionable. Where the restraints do not offend antitrust law, on the other hand, the obvious question is whether there is some distinctive copyright or patent pol- 
icy that justifies nonenforcement. If the question is obvious, the answer is not. In the case of the first sale doctrine the usual answer has been the wholly question-begging assertion that it is simply one of the intrinsic limitations on the property right, with no further explanation of what purpose it serves. A special problem may arise in copyright with contractual restrictions that impede fair use by the end user since fair use is more important to the design of copyright than the first sale doctrine, and attempts to limit it arguably create a deeper conflict with the famous "balance" copyright is said to draw between private and public rights. The most obvious example of such an attempt appears in the case of software licensing restrictions on reverse engineering, which in certain contexts has been accepted as fair use. The fair use here is aligned to antitrust policy. Insofar as reverse engineering is used to enable the development of competitive products, license restrictions on it can easily be made to appear as anticompetitive conduct. This appearance is somewhat misleading, though. Antitrust policy does not require firms to cooperate with competitors in the development or marketing of competing products except in unusual circumstances, and contractual protection of trade secrets is a recognized part of that noncooperative behavior. I don't say the question is an easy one to answer, either way. Where license restrictions on reverse engineering are widespread throughout an industry-as they are in the case of computer software-they might represent such a general threat to the integrity of the intellectual property regime that they should not be enforced, though I am skeptical that this alone can justify invalidating them absent a showing of antitrust injury.

Contractual restrictions on personal property use are one thing, but what about restrictions that are built into the object itself? Chafee did not have to confront the question; in an earlier time, it was a more theoretical than practical problem. In the age of digital works, however, digital rights management tools permit a range of use limitations hitherto impossible or at least impracticable. Needless to say, the same tools that can be used to enforce the legal rights the owner has under property or contract law can also be used to create "rights" that he does not have under those laws. The problem is well known. What to do about it is still a work in progress. In Part IV, I briefly introduce the issue and some of the responses to it. One response, of course, is for users to disable the offending code. Quite apart from the doubtful legality of doing so, there is the obvious problem that for the average user this is simply not an option. Another possibility might be to establish legal restrictions on the kind of code that can be used. The problem with the latter approach is that it requires more regulatory surveillance of product design than is likely to be practicable or acceptable. 
I conclude on a somewhat ambivalent note. Servitude restrictions on personal property can have legitimate purposes. Though I don't argue that these purposes are unconstrained by competing public policies, I do argue that those policies require a closer, and more critical, examination than courts or commentators have usually offered. At bottom the question is whether there is any reason to think the market is any less capable of deciding what kinds of property rights are worth creating and enforcing than it is of deciding what goods to produce.

\section{COMMON LAW SERVITUdES}

The status of personal property servitudes today is confused by the fact that most attempts to create post-sale restrictions on the use or transfer of property involve intellectual property and either are controlled by the specialized rules of patent or copyright law or involve the type of restrictions that are barred by antitrust law. Thus few occasions arise for considering the validity of personal property servitudes as a matter of general common law. However, the conventional wisdom among commentators appears to be similar to what it was when Chafee wrote: such servitudes are the rough equivalent of a liger, the sterile offspring of a male lion and a female tiger that is found only in the occasional zoo. ${ }^{14}$ In 1956 Chafee reported that in the twenty-eight years since his first exploration of the subject he had found only seven cases that could be classified as general common law cases. ${ }^{15}$ I have discovered only a few cases decided since 1956 involving attempts to create common law servitudes, which on first impression would seem to confirm Chafee's conclusion that perhaps the occasions of legitimate use are too few to worry about. However, the rarity of such occasions might simply reflect the common assumption that they are not permitted; in any case, a brief examination of the cases where servitudes have been permitted is worthwhile. A sample of four cases will suffice to illustrate their use.

14 In the wild, presumably there are no places where lions and tigers can get together. Not knowing anything about zookeeping, I can only speculate on how they get together in zoos.

15 Chafee, 69 Harv L Rev at 1255 (cited in note 8). Chafee explicitly excluded from this count numerous resale price fixing cases, which were enforceable under specific state fair trade legislation. When Chafee wrote, state fair trade legislation was allowed as a special exception to the antitrust laws under the Miller-Tydings Fair Trade Amendments, 50 Stat 693 (1937). In 1975 Congress repealed Miller-Tydings, see Consumer Goods Pricing Act of 1975, Pub L 94-145, 89 Stat 801 (1975), codified at 15 USC $\$ \S 1,45(2000)$, which restored the proscription of resale price maintenance per Dr. Miles Medical Co v John D. Park \& Sons Co, 220 US 373 (1911) (finding a minimum resale price of a product in the form of an equitable servitude violative of the antitrust laws). 
In Tri-Continental Financial Corp v Tropical Marine Enterprises $\mathrm{Co},{ }^{16}$ the Fifth Circuit held that a noncompete covenant accompanying the sale of a ship was binding as an equitable servitude on subsequent owners. The original owner of the ship, which used it in ferry operations, sold it to another company subject to a noncompete covenant stating that it could not be operated for ten years in various ports where the original owner was engaged in ferry operations. The original purchaser then sold the ship to another company with the same restrictions. That sale was financed by the plaintiff, who took a mortgage on the ship. Although the mortgage made no mention of the restrictive covenant, plaintiff knew of it. Plaintiff subsequently sued to foreclose on the mortgage and have the covenant declared unenforceable on the grounds that the covenant could not be enforced against third parties and violated antitrust law. The court rejected both claims. On the question of whether the covenant could be enforced against remote owners, the court rejected "the dry as dust and technical common law distinction between chattels and realty" and held that the covenant could be enforced by injunction." The dissenting judge thought that there was "a rational basis of continuing validity for the traditional difference between the principle of law which permits the burdening of real estate with restrictive covenants and that which favors the sale of tangible personal property unencumbered by even known restrictive covenants. ${ }^{.18} \mathrm{He}$ did not, however, explain what that rational basis was.

In Nadell and Co v Grasso, ${ }^{19}$ a California court similarly enforced a restrictive covenant in equity against a remote purchaser of goods. Plaintiff was in the business of buying goods that had been damaged in transit and reselling them. It purchased a shipment of damaged Kraft fruit salad from the carrier subject to a restriction that the fruit salad could not be resold without changing the lids, which bore the Kraft label. Subsequently plaintiff sold part of the shipment to another purchaser who in turn sold it to defendant. Although the defendant had knowledge of the restriction, he refused to abide by it. The court held that the restriction was enforceable as an equitable servitude. It noted that equitable servitudes on land "are limited to those which directly concern and benefit what we may term the dominant

16265 F2d 619 (5th Cir 1959).

17 Id at 626. See also Newman v The Vessel Lady Arnnette, 470 F Supp 520 (D SC 1979) (enforcing against third parties restrictive use conditions on vessels sold by the United States pursuant to a ship disposal program because the covenant imposed no restrictions greater than what was required for protection of the seller's interests).

18 Tri-Continental Financial, 265 F2d at 626-27 (Tuttle dissenting).

19175 Cal App 2d 420, 346 P2d 505 (1959). 
tenement," ${ }^{20}$ but adopted Chafee's suggestion that the restrictions were "a proprietary interest in the articles for the benefit of his business as a dominant tenement.",

The third case, Clairol, Inc v Sarann Co, Inc, resembles Nadell in that the restriction was designed in part to protect product reputation. However, it illustrates another purpose as well: protecting a seller's pattern of distribution. Clairol sold its hair color product in two separate channels. In the professional channel it sold to jobbers who resold to beauty salons and beauty schools for application by beauticians. In the retail channel it sold to wholesalers, jobbers, and direct-buying retailers for ultimate resale to the general public. Both the price and the packaging differed in the two channels. Sales to professional jobbers were at a fraction of the prices charged in the retail channels. The cost differential was primarily a function of market conditions, although there was some cost difference associated with the different packages. One major difference in the packaging was the following caution appearing on the professional package: "Professional Use Only. Warning. Cautionary statements regularly required for sale to non-professionals and instructions essential to the use of this product by nonprofessionals are not included on bottle labels. Non-professional sale may result in prosecution under federal law.",23 Defendant obtained (it is not clear how) the professional product and resold it at retail but in the wholesale package, in which form the instructions and warnings were inadequate to inform consumers about proper use.

Clairol argued that defendant's selling of the product in this manner damaged its good will by exposing consumers to significant harm or disappointment if they used the product improperly. It claimed that this was a form of unfair competition and also a violation of an equitable servitude on the product. The court granted an injunction on both claims. The unfair competition claim was conceded to be somewhat weakened by the fact that the conventional element of deception was not present. On the servitude claim the court found that the "professional use only" warning was sufficient to create a servitude. The absence of an explicit contractual restriction was not critical given the prominence of the warning and the fact that those who purchased the professional product "know that the basis of the price differential they get is their place in the marketing scheme." ${ }^{24}$

20 Id at 509, citing Werner $v$ Graham, 181 Cal 180, 183 P 945, 947 (1919).

21 Nadell, 346 P2d at 510, quoting Chafee, 41 Harv L Rev at 964 (cited in note 5).

$2237 \mathrm{~Pa}$ D \& C 2d 433 (1965).

23 Id at 436.

24 Id at 454. Clairol's apparent purpose here was price discrimination between the two classes of buyers, though it is possible that the discount it gave to professional beauticians was also an implicit compensation for promoting the product. I discuss both of these purposes in the 
The fourth case, TransWorld Airlines, Inc $v$ American Coupon Exchange, Inc, also involved protecting a particular pattern of distributing goods. At issue was the enforceability of restrictions on the transferability of airline frequent flyer mile coupons. Under the tariffed rules governing the granting of frequent flyer miles, persons entitled to an award of frequent flyer miles could request a certificate in their own name or the name of a family member, legal dependant, or relative. Any certificate issued to anyone other than a family member, legal dependent, or relative was void, as was any certificate deemed to have been sold or bartered. Notwithstanding the transfer restriction, defendant brokered the mileage awards, buying coupons from awardees and selling them to other travelers at discounted prices. Coupon buyers were advised by defendant to pretend to be a relative of the program member from whom the award was purchased when they presented the coupons to airlines or travel agents for the issuance of a ticket.

The airline's first step to stop brokerage of the coupons was simply to refuse to honor tickets purchased with brokered award coupons. Its second step was to sue the broker, claiming fraud and intentional interference with business relations. Defendant claimed the restrictions were unreasonable restrictions on the transfer of "travel rights" and therefore contrary to the public policy against restraints on alienation of property. The district court granted summary judgment for the airline, finding that the rules were a reasonable effort to balance the benefits of publicity and customer loyalty against the cost of providing travel awards, and that absent some restrictions on transferability it might be necessary to increase the cost of regular airfares. ${ }^{26}$ The Ninth Circuit found the district court's rationale too speculative to support a grant of summary judgment. It nevertheless affirmed the lower court's holding that the policy against restraints on alienability of property was not applicable because the coupons were not property, but rather the restrictions were a matter of contract and contractual restrictions against assignment of rights are generally enforceable. ${ }^{27}$ Of course, the mechanism for enforcement of the restriction here was a tort action for interference with business relations, but the effect was the same as enforcing the contract as an equitable servitude. ${ }^{28}$

context of Acrobat software below. See notes 202-14 and accompanying text.

25913 F2d 676 (9th Cir 1990).

26 Trans World Airlines, Inc v American Coupon Exchange, Inc, 682 F Supp 1476 (CD Cal 1988)

27 TransWorld Airlines, 913 F2d at 685-86.

28 American Airlines v Christensen, 967 F2d 410, 412-15 (10th Cir 1992), similarly used an interference-with-contract theory to enforce a restriction on sale of airline mileage awards 
Of the four cases, TransWorld Airlines is the most interesting for its artful-if disingenuous-dodge of the restraint-on-alienability issue. The result is sound, as I shall argue further in a moment, but the court's use of the contract-property distinction as a means of avoiding it is artificial. The court itself acknowledged as much:

Unfortunately, this bare dichotomy [between contract and property] is not very helpful without more. "Property rights" and "contract rights" do not have independent existence in the world as natural kinds, detached from any consideration of human purposes. Nor are the categories mutually exclusive in common usage: When property changes hands, it quite often does so pursuant to a contract (as in this case); and contract rights, having an economic value (again, as in this case), are often referred to as "property," as they surely are for some purposes. If the distinction between the two bodies of law is to be maintained and preserved from degenerating into a jurisprudence of labels, it should be applied only after considering the competing policies underlying the doctrines in question. ${ }^{29}$

However, the court itself did not manage to escape this "jurisprudence of labels." In the end it simply fell back on the "familiar resemblance" theory of precedent. Citing a line of cases involving railroad and theater tickets where the courts enforced contractual restraints on transfer, ${ }^{30}$ the court concluded that the frequent flyer coupons resembled those cases. ${ }^{31}$

Given the court's recognition of the artificiality of the contractproperty distinction in this case, there was no reason to resort to the contract label simply to avoid confronting the policy against restraints on alienability. The distinction between property and contract rights

against a third-party broker. Interference with contract was also the basis for enforcing contractual restrictions on the transfer of trading stamps against third parties who bought the stamps in order to create a secondary market for them in Sperry \& Hutchinson Co v Fenster, $219 \mathrm{~F} 755$ (ED NY 1915).

29 TransWorld Airlines, 913 F2d at 686 (internal citation omitted).

30 Id at 686-87, citing, inter alia, Bitterman v Louisville \& Nashville Railroad Co, 207 US 205 (1907) (railroad tickets); Collister v Hayman, 183 NY 250, 76 NE 20 (1905) (theater tickets).

31 TransWorld Airlines, 913 F2d at 689.

32 In United States $v$ Loney, 959 F2d 1332 (5th Cir 1992), the court held that frequent flyer coupons were properly classified as property for purposes of the federal wire fraud statute (making it a crime to obtain money or property by false pretenses). Defendant, relying on TransWorld Airlines, argued that his scheme to add bogus airline mileage to frequent flyer awards did not come within the statute's prohibition because the award coupons were not property. The court distinguished TransWorld Airlines on the grounds that the purpose of classifying the frequent flyer awards as contract rather than property rights in that case was simply to avoid the public policy against restraints on alienation. For purposes of the federal fraud statutes, however, the term "property" included "things of value." Loney, 959 F2d at 1335-36. 
is conventional and for many purposes sensible. ${ }^{33}$ We often need to distinguish between rights enforceable against everyone and rights enforceable only against persons with whom there is a special relationship. However, the distinction is easily overdrawn: there are few property rights that are good against everyone, and contract rights can often be enforced against third persons, as in the case of equitable servitudes or tort actions for interference with contract. Given the slipperiness of the distinction at the margins, courts should not let public policy judgments rest merely on conventional categorization. A public policy that turns on artful labeling cannot be very robust. If there is a good reason to allow restrictions on the transferability of the coupons, as in the ticket cases, it should not matter whether the rights of the coupon holder are labeled as property rights or as contract rights. By allowing the transfer restriction to be enforced against third parties, the court in TransWorld Airlines was effectively treating the restriction as a property servitude, identical in all practical respects to conventional real property servitudes. In the real property context no one has any difficulty recognizing that a restrictive covenant becomes a property right by virtue of being enforceable against third persons; there is no obvious reason why it should be different for personal property. By the same token the fact that the enforcement in these cases is by means of a tort action for interference with contractual relations should not obscure the fact that the interference tort is, in effect, a recognition that the promisee has a property right in the promise. $^{34}$

But I am running ahead of the story. I shall have to return to the contract-property distinction since it is a prominent feature of the debate over license restrictions in the field of intellectual property, which

33 For a theoretical explanation of the distinction in terms of the different information costs associated with property and contract, see Thomas W. Merrill and Henry E. Smith, The Property/Contract Interface, 101 Colum L Rev 773 (2001).

34 The use of the interference tort to create property rights has been recognized by many commentators. See, for example, Henry Hansmann and Reinier Kraakman, Property, Contract, and Verification: the Numerus Clausus Problem and the Divisibility of Rights, $31 \mathrm{~J}$ Legal Stud S373, S410 (2002); Fred S. McChesney, Tortious Interference with Contract versus "Efficient" Breach: Theory and Empirical Evidence, $28 \mathrm{~J}$ Legal Stud 131 (1999); Edmund W. Kitch, Intellectual Property and the Common Law, 78 Va L Rev 293, 299-300 (1992); Richard A. Epstein, Inducement of Breach of Contract as a Problem of Ostensible Ownership, $16 \mathrm{~J}$ Legal Stud 1, 19-21 (1987). Courts have also expressly grounded the tort action in terms of protecting the promisee's property right in performance: "The right to perform a contract and to reap the profits therefrom, and the right to performance by the other party, are property rights." Downey v United Weatherproofing, Inc, 363 Mo 852, 253 SW2d 976, 980 (1953), citing Annotation: Liability for Procuring Breach of Contract, 84 ALR 43, 46 (1933); Johnson v Gustafson, 201 Minn 629, 277 NW 252, 254 (1938) (same). See also Second National Bank of Toledo v M. Samuel \& Sons, Inc, 12 F2d 963, 967 (2d Cir 1926) ("Contract rights are property, and as such are entitled to the protection of the law, and knowingly to induce one of the parties wrongfully to repudiate a contract is as distinct a wrong as it is to injure or destroy property."). 
in turn is the primary modern context in which the concept of enforceable personal property servitudes appears.

At the outset a brief comment is in order about translation problems raised by extrapolating servitude principles from one type of property to another. The move from real property to personal property is fairly straightforward inasmuch as both types of property involve essentially similar common law foundations. Granted, there are some differences between real property and personal property applications. In the real property context servitudes are conventionally justified as an efficient means of controlling externalities or neighborhood effects among land uses. ${ }^{35}$ By correcting negative externalities (or creating positive externalities), use restrictions can confer reciprocal benefits on both benefited and burdened land owners. This justification does not find a perfect counterpart in the case of personal property. Use restrictions are imposed to serve the seller's general commercial purposes, not to enhance the value of the restricted good by correcting for externalities among owners. The distinction is not, however, substantively important. Although land restrictions can be an efficient means of controlling for externalities, this is not a necessary condition of their enforcement. Apart from public policy restraints on socially obnoxious restrictions, the only legal limitation on "inefficient" covenants is the touch and concern requirement, preventing idiosyncratic covenants from running with the land, which is so rarely applied that modern scholars have concluded it should be abandoned. ${ }^{36}$

Even if efficiency were a prerequisite to enforcement of servitudes, that would not privilege land servitudes over personal property servitudes. As the cases noted earlier illustrate, personal property servitudes typically involve commercial transactions where a seller, usually a merchant in the goods being sold, has a business purpose in imposing the restriction. This may not prove that the restriction is optimally efficient, but it is enough to meet the minimal purposes that the law requires-as reflected, for instance, in the touch and concern requirement. A merchant who sought to burden his goods with eccentric use restrictions that under the common law would not "touch and

35 See, for example, Uriel Reichman, Toward a Unified Concept of Servitudes, 55 S Cal L Rev 1177, 1231-32 (1982) (describing how "servitudes are used to transfer owners' entitlements, other than possession, for the efficient utilization of land").

36 The latest Restatement of Property, reflecting a growing body of scholarly opinion that believes the touch and concern doctrine is just a confusing artifact of history, concludes that it is "superseded," leaving only specific limitations on certain restraints, such as those that impose unreasonable restraints on alienation or violate some other public policy. Restatement (Third) of Property (Servitudes) $\$ 3.2$ (1998). 
concern" would not remain in business long enough for the law to worry about.

However, the argument over relative efficiency is somewhat misdirected to the extent it suggests that the exercise of property rights is subservient to efficiency norms, when the reverse is more nearly true. As a baseline, I start with the premise that the power to restrict use is intrinsic to the power to transfer (or not), which is fundamental to the concept of property rights. Exercising that power means, of course, that prior owners can limit the rights of subsequent owners; this simply reflects the temporal order of property rights: first owners determine the rights of second owners. We could reverse the sequence, but it isn't easy to explain why the second owner's right to unburdened use of property should trump the first owner's rights to burden the property. It also isn't easy to see why that explanation, whatever it is, should be any different for real and personal property.

Translating servitude principles from real property to personal property thus seems to me reasonably straightforward, though I will take up later some special arguments why public policy reasons might differ from one case to the other. Moving from common law property to intellectual property is a bit more difficult because of fundamental differences in the property rights regimes. Tracing out the differences between common law and intellectual property rights at length would require a large detour, one which we fortunately need not take, because the distinctions turn out not to matter very much in the present context. $^{37}$

Consider the distinction based on the different character of the underlying goods, which is a conventional jumping off point for distinguishing between common law and intellectual property. Common law property involves goods that are generally rivalrous in use: two persons cannot plow the same furrow. For rivalrous goods, exclusive property rights ensure efficient management of use and induce efficient production by allowing owners to internalize the full benefits from the goods. ${ }^{38}$ In contrast, intellectual property involves nonrivalrous ("public") goods where one person's use does not diminish another's, hence exclusive property rights are not needed-and not efficient - to manage use. They are needed only to provide the incentive

37 For an extended comparison of common law and copyright "entitlement structures," see Wendy J. Gordon, An Inquiry into the Merits of Copyright: The Challenges of Consistency, Consent, and Encouragement Theory, 41 Stan L Rev 1343, 1354-94 (1989). Gordon concludes that the copyright regime is "functionally as well as structurally consistent with [the regime governing] tangible property." Id at 1378.

38 See, for example, Harold Demsetz, Toward a Theory of Property Rights, 57 Am Econ Rev Papers \& Proceedings 347 (1967) (theorizing property rights as "guiding incentives to achieve a greater internalization of externalities"). 
to produce the goods. Absent exclusive property rights, successful inventions or expressive works would be quickly copied and sold by others at their marginal production cost. This would leave the inventor/creator unable to recoup the costs of invention/creation and hence would undermine the incentive to produce in the first place. ${ }^{39}$ However, for this limited purpose it is conventionally assumed that the rights of ownership can and should be more limited than they are for common law property, particularly given that intellectual property rights can have a broader foreclosure effect, excluding others from a generic class of objects as opposed to a specific object.

The idea that intellectual property rights should be more limited than common law property rights is unexceptional, but it is also incomplete since it does not inform us what the limits on the former should be. In all events, as we shall see, the limitations that are a central concern of this Article are in fact grounded in common law policies-or at least policies that are not unique to intellectual property. There may be special complications that are not shared by common law and intellectual property regimes, ${ }^{41}$ but an examination of the rules and policies that arise in the context of servitudes shows that common themes and arguments predominate.

39 See, for example, Gideon Parchomovsky and Peter Siegelman, Towards an Integrated Theory of Intellectual Property, 88 Va L Rev 1455, 1458-59 (2002). Notice that this argument does not distinguish intellectual property from common law property except perhaps to the extent it assumes that the free-riding costs are lower in the former than the latter. It is the premise of all utilitarian accounts of property that no one will invest in the production of economically valuable resources of any kind without some assurance that they will be able to recoup the cost of their investment. This point is at the core of current disputes over forcing firms to share their productive assets with other firms. See, for example, Glen O. Robinson, On Refusing to Deal with Rivals, 87 Cornell L Rev 1177, 1190-91 (2002) (discussing forced sharing in the context of antitrust and regulatory policy).

40 There have always been doubts about whether patents or copyrights are needed at all: Arnold Plant was one of the leading doubters. See Arnold Plant, The Economic Theory Concerning Patents for Inventions, 1 Economica 30, 51 (new series 1934); Arnold Plant, The Economic Aspects of Copyright in Books, 1 Economica 167 (new series 1934). Plant argued that patent and copyright laws simply diverted productive effort from certain kinds of activities to others, and there was no reason to think the latter were socially more useful than the former. Since Plant wrote, a huge literature has developed that challenges the traditional incentive assumptions underlying patent and copyright; much of it is devoted to exploring alternative incentives to induce inventive or creative works. See, for example, Stephen Breyer, The Uneasy Case for Copyright: $A$ Study of Copyright in Books, Photocopies, and Computer Programs, 84 Harv L Rev 281 (1970) (questioning the case for property rights in copyrighted works and discussing alternative regimes); Michael Abramowicz, Perfecting Patent Prizes, 56 Vand L Rev 115 (2003) (discussing proposed patent reward systems, where right holders sell their exclusive use right to the government, as an alternative to the current patent monopoly regime).

41 One complication suggested to me by Clarisa Long is a difference in the information costs associated with the restrictions in the two types of property regimes. I deal with information costs later. See text accompanying notes 126-38. At this point it is enough to say that the information cost problem as it affects special restrictions on use or resale of the property does not seem to me to be materially greater in one property regime than in another. 


\section{POST-"SALE" RESTRICTIONS ON INTELLECTUAL PROPERTY}

If the common law of property has been inhospitable to the idea of chattel servitudes, the statutory law of intellectual property has been more so. Post-transfer restrictions on copyrighted, patented, or trademarked goods have been barred by the first sale doctrine for more than a century. However, there always has been some uncertainty about the scope of the rule, most notably whether it can be avoided by structuring the transfer of rights as licenses rather than sales. In recent years that uncertainty has become the subject of an explosive controversy in copyright law concerning the legality of software license restrictions, and a less explosive but still noteworthy controversy in patent law over various license restrictions on the use and sale of patented goods. Although the first sale doctrine also applies to trademarked goods, ${ }^{42}$ as noted above, trademark disputes do not add any distinctive principle or policy that is not present in patent and copyright law; thus the following discussion focuses on copyright and patent law.

\section{A. Patents and First Sale}

Bloomer v McQuewan ${ }^{43}$ appears to be the first case to articulate the first sale rule, though the context was such as to make it unclear exactly what the principle was. Defendants had purchased the right to make and use a certain number of patented planing machines from the original patentee. After the original patent expired Congress extended the term of patents. The rights under the extended patent were assigned to the plaintiff who then claimed that the defendants' right to continue using the planing machines had terminated. The Court distinguished between the patent right and the articles made pursuant to it, holding that while the patent rights expired at the end of the patent term, this did not affect the right to use articles validly made pursuant to the original patent. ${ }^{4}$

The distinction between the patent and the machines is intuitive in this context because we naturally assume that the purchaser of a patented article is buying the physical machine as well as the license to use it pursuant to the patent. For plaintiff's argument to make any sense one would have to imagine that the parties understood the transaction to be simply a lease of the machine for the duration of the

42 See, for example, Sebastian International, Inc v Longs Drug Stores Corp, 53 F3d 1073, 1074 (9th Cir 1995) (finding that the subsequent resale of trademarked articles in violation of the owner's restrictions on distribution does not constitute trademark infringement or unfair competition).

4355 US (14 How) 539 (1852).

44 Id at 549. 
patent life. Such a lease is not inconceivable, perhaps, but such an odd arrangement does not commend itself as a plausible interpretation of the transaction.

In other contexts, though, the distinction between the patent and patented article becomes more problematic. Adams $v$ Burke, decided some twenty years after Bloomer, is illustrative. In Adams the patentees of an improved coffin lid gave an exclusive assignment to a manufacturer to use, make, and sell the patented coffin lid within a limited territory. The rights to use, make, and sell outside that territory were subsequently assigned to the plaintiff, Adams. The first assignees sold coffins with the patented lids to the defendant, Burke, an undertaker who used the coffins outside the prescribed territory where the assignee was authorized to use or sell the patented lids. Adams sued Burke for infringement. The Court held that the territorial restriction that bound the original assignee did not bind the purchaser of the coffins because

the patentee or his assignee having in the act of sale received all the royalty or consideration which he claims for the use of his invention in that particular machine or instrument, it is open to the use of the purchaser without further restriction on account of the monopoly of the patentees.

Following Adams, the Court regularly repeated the rule but with no useful elaboration of the principle underlying it beyond the simple assertion that the patentee is deemed to have received his full patent reward from the sale price of the patented good. ${ }^{47}$ shall have more to say about this "single-reward" theory later $;^{48}$ for now it is enough to note that it begs the question of why a patentee should be required to collect all of its rewards from a single form of compensation for unrestricted use. In any case it is not clear that the Adams Court intended to limit the patentee to a single-reward notion in all cases. The Court implied that the use restriction might have been enforced if it had been made an express contractual condition, ${ }^{49}$ and twenty years later explicitly reserved judgment on the question of whether express re-

4584 US (17 Wall) 453 (1873).

46 Id at 456 .

47 The single-reward idea appeared earlier in Mitchell $v$ Hawley, 83 US (16 Wall) 544, 547 (1872) (stating that a patentee is "never entitled to but one royalty for a patented machine"), and was ritualistically repeated in later cases. See, for example, Keeler v Standard Folding Bed Co, 157 US 659, 666 (1895) (affirming the single-reward idea and noting that "one who buys patented articles . . . becomes possessed of an absolute property in such articles, unrestricted in time or place"); United States v Univis Lens Co, Inc, 316 US 241, 251 (1942) (same).

48 See text accompanying notes 165-67.

49 The Court noted that the restriction was not "contemplated by the statute nor within the reason of the contract," Adams, 84 US at 456, implying that an express contractual restriction could have produced a different outcome as a matter of contract, if not patent, law. 
strictions on use or resale could be enforced as a matter of contract law. The Court seemed to indicate, however, that such restrictions could not be enforced under contract law in a series of decisions invalidating explicit license conditions restricting resale. ${ }^{51}$ These decisions might be distinguished as independent of the first sale doctrine on the grounds that the restrictions were unlawful trade restraints. However, the Court made no such distinction and the decisions can be reasonably interpreted to hold that the first sale doctrine was a fixed limitation, not simply a default rule.

They could be, that is, until the Federal Circuit's decision in Mallinckrodt, Inc $v$ Medipart, Inc, ${ }^{53}$ holding that the first sale doctrine was merely a default rule and did not preclude contractual (licensing) restrictions on use or resale. In Mallinckrodt the patentee sold patented medical nebulizer devices to hospitals, each marked "Single Use Only." However, instead of disposing of the used device as directed, some hospitals shipped them to defendant who "reconditioned" them and sold them back to the hospitals. The patentee sued the defendant for, among other things, patent infringement. The district court rejected the licensing restriction, holding that the single use restriction was invalid under the first sale rule, and that defendant's reconditioning of the device was not a reconstruction but merely a "repair" of the

\section{Keeler, 157 US at 666:}

Whether a patentee may protect himself and his assignees by special contracts brought home to the purchasers is not a question before us, and upon which we express no opinion. It is, however, obvious that such a question would arise as a question of contract, and not as one under the inherent meaning and effect of the patent laws.

51 See Motion Picture Patents Co v Universal Film Manufacturing Co, 243 US 502 (1917) (invalidating an attempt to place a restriction on use of the licensed machine through attaching notice of such restriction to the machine on the grounds that patent law does not extend past the invention of the patent); Straus v Victor Talking Machine Co, 243 US 490, 501 (1917) (finding that resale price restrictions imposed in a "license notice" attached to a product are invalid as "mere price-fixing"); Univis Lens Co, 316 US at 250-51 (invalidating resale price restrictions in license agreements for patented items on grounds that the "sale of [the patented item] exhausts the monopoly").

52 "Reasonably interpreted" does not mean the matter was free from doubt. For example, in United States v General Electric Co, 272 US 476 (1926), the Court upheld a resale price restriction imposed on dealers who were appointed as "agents" of the manufacturers. In antitrust law this case is treated as an exception to the rule that resale price restraints are per se unlawful, an exception limited to those cases where the distributor is an "agent" of the manufacturer. It is noteworthy, however, that the Court's opinion is much broader and suggests that a patent owner can impose by license any conditions that "are normally and reasonably adapted to secure pecuniary reward for the patentee's monopoly." Id at 490. In General Talking Pictures Corp v Western Electric Co, 305 US 124 (1938), the Court followed General Electric in upholding field-of-use restrictions imposed by means of a "license notice" on manufacturers; however, the Court noted a possible distinction between application of these restrictions to manufacturers (as in General Electric and the instant case) and purchasers to whom the articles were ultimately sold. Id at 127.

53976 F2d 700, 701 (Fed Cir 1992). 
device, and hence not an infringement. ${ }^{54}$ The court explained the underlying "social objectives" for banning post-sale restrictions as a

pragmatic judgment that, in general, people both expect and should be able to use the goods they purchase without restraints from merchants and manufacturers. it [sic] also represents a parallel judgment that the interest in preventing restraints on use is stronger than the opposing interest in permitting a patent owner to use his monopoly to increase sales of his invention. ${ }^{\text {ss }}$

The district court's first explanation about expectations makes no sense as a factual statement. If buyers are given a clear statement about what they are purchasing - a single use of a device - they have no basis for any other expectations. Perhaps what the court meant to say was that people have a right to expect that every purchase necessarily conveys a certain standard set of rights from which no deviation will be permitted. However, such a meaning is oddly formalistic if not just silly. By that reasoning every sale of a house would have to be the sale of a fee simple estate. The second explanation provided by the district court is, at best, unhelpful. Plainly, if all use restrictions are forbidden this conclusion follows, but it doesn't say anything about why one interest outweighs another.

Both explanations are in any event quite at odds with the very next sentence, which limits the scope of the holding to patent infringement actions only: "We do not intimate any view about whether Mallinckrodt's 'Single Use Only' restriction might be enforceable on a legal theory other than patent infringement-as a matter of contract law or property law or anything else. See Chaffee [sic], Equitable Servitudes on Chattels, 41 Harv.L.Rev. 945, 953, 999-10005 [sic] (1928)., ${ }^{, 56}$ If the first sale rule represents the kind of social objectives just explained, it is hard to see why those same objectives would not bar an action under "contract law or property law or anything else." I take it that what the district court had in mind here-as suggested by the reference to Chafee's article-is the creation of a servitude on the patented device; of course, it is in the nature of property servitudes that they create in rem obligations binding on persons who otherwise have no relationship to the creator of the obligation. Presumably that would include the defendant in this case.

The Court of Appeals for the Federal Circuit did not consider the possibility of a distinction between patent rights on the one hand and common law rights on the other. It simply reversed the district court's decision on the grounds that a patentee could expressly condition the 
use of goods providing the conditions did not independently amount to a misuse of the patent-as, for example, by imposing restrictions that were illegal under the antitrust laws. ${ }^{\text {s. }}$ The court reviewed and distinguished the entire line of Supreme Court first sale cases as based either on the absence of an explicit condition or on a finding that the particular condition was illegal (most notably because it was a tying or a price fixing condition which had been separately condemned under antitrust law). Moreover, the court rejected the notion that the legality of post-sale restrictions could turn on the "formalistic" distinction between a sale and a license.

Mallinckrodt, of course, did not purport to eliminate the first sale doctrine; after all, the doctrine-whatever it means-has the imprimatur of a century and a half of Supreme Court decisions. Subsequent Federal Circuit cases still faithfully recite the first sale doctrine more or less in its traditional form, but make clear that it is purely a default rule to be applied where there is no express contractual restriction. ${ }^{59}$ Some critics have claimed that Mallinckrodt and its progeny have cut the heart out of the first sale doctrine. ${ }^{60}$ Whether they have or not depends on what the doctrine meant before Mallinckrodt. It appears that most commentators wanted it to mean that post-sale restrictions not only would not be implied in a sale or license of patented goods but would not be allowed as a matter of public policy. Although that meaning finds support in prior Supreme Court cases, it is not as clear as it might have been, as is evident from the district court's opinion. As I noted, the district court thought that post-sale restrictions were contrary to public policy, but then confusingly went on to allow for the possibility that a court might enforce an express restriction as a matter of common law contract or property.

57 Mallinckrodt, 976 F2d at 708-09.

58 Id at 704-05.

59 See, for example, Intel Corp v ULSI System Technology, Inc, 995 F2d 1566, 1568 (Fed Cir 1993) (noting that the first sale doctrine is "well settled" and refusing to infer a restriction on use from the contract).

60 See, for example, Julie E. Cohen and Mark A. Lemley, Patent Scope and Innovation in the Software Industry, 89 Cal L Rev 1, 33-35 (2001) (criticizing Mallinckrodt as "expanding the contractual exception to swallow the rule"); James B. Kobak, Jr., Contracting around Exhaustion: Some Thoughts about the CAFC's Mallinckrodt Decision, $75 \mathrm{~J}$ Pat \& Trademark Office Socy 550 , 559-64 (1993) (noting the potentially far-reaching implications of the Mallinckrodt decision and predicting that it will lead to overreaching by patent-holders in the types of restrictions imposed by contract).

61 Patent misuse is not in and of itself a tort or antitrust violation, and hence does not create an independent cause of action, although the underlying conduct might be the basis for an independent tort or antitrust claim. See, for example, George Gordon and Robert J. Hoemer, Overview and Historical Development of the Misuse Doctrine, in Intellectual Property Misuse: Licensing and Litigation 1 (ABA 2000). However, to the extent misuse is considered against public policy for purposes of barring a patent claim, one might think it sufficient grounds for barring a common law claim as well. 
Whether or not Mallinckrodt's interpretation of the prior cases was accurate, it at least had the virtue of what Harold Bloom once called (in the context of literary interpretation) a "creative misreading" of the prior texts, ${ }^{62}$ which is to say that it provided a foundation for new understanding of a doctrine that had become more slogan than policy. Not least of Mallinckrodt's contributions was its elimination of the formalistic distinction between sale and licensing-a distinction that continues to plague the copyright cases applying the first sale doctrine. ${ }^{63}$ There are, of course, differences between a sale and a license, but attempting to use those differences as the basis for validating or invalidating use restrictions has served only to promote artificial classifications that obscure the underlying purposes and effects (good and bad) of those restrictions.

Equally important was Mallinckrodt's separation of the first sale principle and misuse by rejecting the notion that post-sale restrictions are per se misuse. ${ }^{64}$ The conflation of post-sale restrictions with misuse is understandable given that both are typically characterized as attempts by patentees to claim more than their fair entitlements under the patent grant. However, characterizing all restrictions as per se misuse is both conclusory and obfuscating since it has the effect of foreclosing an inquiry into the actual purposes and effects of the restriction; without this inquiry it is impossible to say whether or not it is within the scope of the patent entitlements.

62 Harold Bloom, The Anxiety of Influence: $A$ Theory of Poetry xlv (Oxford 2d ed 1997).

63 Despite Mallinckrodt's refusal to attach decisive importance to the sale-license distinction, a more recent Federal Circuit decision, Monsanto Co v McFarling, 302 F3d 1291 (Fed Cir 2002), suggests it might still have some formalistic importance. Monsanto held a patent for genetically modified plants that were resistant to certain herbicides, allowing the herbicide to be sprayed in planted fields without harming the resistant crops. Monsanto licensed the manufacture and sale of the patented seeds to farmers. Buyers were required to sign an agreement that the seeds were to be used for planting a commercial crop "only in a single season" and that forbade the user to "save any crop produced from this seed for replanting, or supply saved seeds to anyone for replanting." Id at 1293 . Defendant violated the agreement by saving part of the crop grown with the modified seeds purchased from Monsanto and using it as seed in the next planting season. In an action both for infringement and breach of contract, defendant invoked the first sale doctrine. The court rejected the defense on the grounds that the seed had not been sold but merely licensed:

The "first sale" doctrine of exhaustion of the patent right is not implicated, as the new seeds grown from the original batch had never been sold. The price paid by the purchaser "reflects only the value of the 'use' rights conferred by the patentee." The original sale of the seeds did not confer a license to construct new seeds, and since the new seeds were not sold by the patentee they entailed no principle of patent exhaustion.

Id at 1299 (internal citation omitted).

64 Mallinckrodt, $976 \mathrm{~F} 2 \mathrm{~d}$ at 704 (noting that prior cases rejecting post-sale restrictions were grounded in objections to price fixing rather than in a principle that all post-sale restrictions were per se illegal). 


\section{B. Copyright and First Sale}

The first sale doctrine made its first appearance in copyright law in 1908 in Bobbs Merrill Co v Straus. ${ }^{65}$ Bobbs Merrill sought to fix the resale price of its books by means of a notice printed in every copy of the book sold to retailers. ${ }^{66}$ When defendant retailer (Macy's Department Store) sold the book at less than the posted resale price, Bobbs Merrill sued for copyright infringement on the grounds that a sale in violation of the resale price restriction violated its exclusive right to sell. The Court held that such a resale did not infringe the copyright because an owner's exclusive right to sell does not extend beyond the first sale of the copyrighted work. ${ }^{6 ?}$

The Court in Bobbs Merrill did not articulate any policy basis for its new rule beyond simply declaring that a copyright owner's exclusive right to sell did not authorize restrictions on the resale of the copyrighted work. Today, the first sale doctrine is commonly associated with the public policy against restraints on alienation and with antitrust policy against restraints of trade. ${ }^{68}$ I shall defer discussion of these policies, but it should be noted here that neither rationale appears in Bobbs Merrill. The Court characterized its decision as simply one of statutory interpretation to determine whether the power to condition resale of the book was inherent in the publisher's copyright. Giving a negative answer to that question, the Court found no need to consider whether resale restrictions were contrary to public policy; thus it finessed the question of whether the restrictions might be separately enforced under contract law. ${ }^{69}$

A few years later the Court did hold that an agreement to fix resale prices violated the Sherman Act as well as the common law policy

65210 US 339 (1908).

66 Id at 341. Bobbs Merrill's resale price restriction was part of an industrywide price fixing scheme which had been found to violate New York's antitrust law just four years earlier. Straus v American Publishers' Association, 177 NY 473,69 NE 1107 (1904). The illegality of the price fixing played no role in the Supreme Court's decision in Bobbs Merrill, but three years later the Court in Dr. Miles Medical Co v John D. Park \& Sons Co, 220 US 373 (1911), would declare that resale price fixing also violated federal antitrust law.

67 Bobbs Merrill, 210 US at 351. Oddly, the Court did not rely on the earlier patent first sale cases. Unaccountably, the Court concluded that "[a] case such as the present one, concerning inventions protected by letters patent of the United States, has not been decided in this court, so far as we are able to discover." Id at 343. How the Court missed the relevance of patent cases like Adams v Burke and Keeler v Standard Folding Bed is a puzzle, but it suggests at least that the first sale doctrine was not fully recognized even in patent law at this time. In fact, the Court even drew a distinction between patent and copyright law on this point by suggesting that perhaps a patentee might have rights that a mere copyright owner did not have to restrict the use or resale of goods. Id at 345-46.

68 See, for example, Melville B. Nimmer and David Nimmer, 2 Nimmer on Copyright $\S 8.12$ (A) (Matthew Bender 2002).

69 Bobbs Merrill, 210 US at 351. 
against restraints on alienation, ${ }^{10}$ which seemed to render moot the question of whether one could contract around resale price fixing. In fact it did not. For one thing, the proscription on resale price fixing applies only to agreements and does not preclude enforcing resale price restrictions by a simple refusal to deal with retailers who refused to sell at the prescribed prices." For another, the proscription against price fixing does not automatically extend to agreements for nonprice restrictions.

What the Court in Bobbs Merrill did not say, Congress should have said but did not. A year after Bobbs Merrill, the 1909 revision of the Copyright Act expressly confirmed that a copyright owner's exclusive distribution right did not extend beyond the first sale of the copyrighted article ${ }^{73}$ but the legislative history is no more illuminating as to the underlying policy than was the Court's decision. Most of the discussion of the issue focused on whether the language describing the exclusive distribution right left the ruling intact or impliedly overruled it. $^{74}$ To allay the concerns of those who thought that language granting the exclusive right "to vend the copyrighted work" might be construed

70 Dr. Miles, 220 US at 402, 408. The relationship between the Sherman Act and common law property grounds for the decision is unclear. In C. Paul Rogers III, Restraints on Alienation in Antitrust Law: A Past with No Future, 49 SMU L Rev 497, 506 (1996), the author argues that the Court believed the latter was a necessary predicate of the former. Perhaps, but the opinion is so opaque one cannot be sure. The common law policy discussion, complete with references to Lord Coke, appears by way of rebutting the defendant's argument that its right to fix resale prices was an intrinsic component of its property right in the goods. Dr. Miles, 220 US at 404-09.

71 See United States $v$ Colgate \& Co, 250 US 300 (1919) (upholding the ability of a manufacturer to refuse to supply product to retailers who would not sell at a specified price as not satisfying the contract requirement to be a Sherman Act violation). Although later Supreme Court decisions restricted the scope of Colgate almost to the vanishing point, the lower courts managed to keep it alive. See Glen O. Robinson, Explaining Vertical Agreements: The Colgate Puzzle and Antitrust Method, 80 Va L Rev 577, 583 n 23 (1994) (reporting on lower court applications of Colgate). In Monsanto Co v Spray-Rite Service Corp, 465 US 752, 761 (1984), distinguishing between permissible independent action and impermissible concerted price fixing, the Court itself reaffirmed and reinvigorated the Colgate doctrine. Colgate and Monsanto suggest an alternative means, other than by agreement, for imposing post-transfer restrictions on the sale or use of copyrighted and patented goods in cases where the restrictions are imposed on intermediate distributors: the copyright or patent holder can simply announce the restrictions and refuse to do repeat business with anyone that does not abide by them. This refusal-to-deal remedy, of course, does not entail an infringement action, so the only way in which the first sale doctrine could be raised would be in a separate action to declare the refusal to deal unlawful. The only basis for such a claim that comes to mind would be an antitrust monopolization claim, but even that claim would be viable only if there were no legitimate business justification. See Aspen Skiing Co v Aspen Highlands Skiing Corp, 472 US 585 (1985) (holding a monopolist liable for refusal to deal with a rival in the absence of any business justification).

72 Continental TV, Inc v GTE Sylvania, Inc, 433 US 36 (1977) (finding that franchise agreements fixing exclusive territories for retailers are not per se illegal, in contrast with the per se prohibition on price fixing agreements, and should be considered under the rule of reason).

73 Pub L No 60-349, 35 Stat 1075 (1909).

74 See generally E. Fulton Brylawski and Abe Goldman, eds, 5 Legislative History of the 1909 Copyright Act (Rothman 1976). 
to overturn Bobbs Merrill, Congress distinguished the property in the material object from the copyright and provided further that nothing in the Act "shall be deemed to forbid, prevent, or restrict the transfer of any copy of a copyrighted work the possession of which has been lawfully obtained." ${ }^{75}$ That merely confirmed Bobbs Merrill as to the scope of the exclusive distribution right. ${ }^{76}$ Neither the 1909 Act nor its legislative history suggests a general policy against restraints on alienability apart from the antitrust policy against price fixing. On the contrary, the legislative history indicates that Congress left open the possibility of imposing resale restrictions by contract."

The first sale doctrine received little further clarification after its 1909 incorporation. Cases applying the doctrine affirmed that it barred a claim for copyright infringement against those who obtained copyrighted articles in violation of a distribution restriction, but they did not resolve the question of whether an owner might have other means of enforcing such a restriction. For example, in Burke \& Van Heusen, Inc v Arrow Drug, Inc, ${ }^{78}$ the owner of copyrights to certain musical compositions sold LP records of those compositions to a shampoo manufacturer for the purpose of distributing the records as a premium in connection with the sale of the shampoo. The LPs were sold under a license that limited their distribution to occur only with the shampoo. However, when the shampoo was sold to defendant drug store, the store resold the records separately from the shampoo. The court held that the first sale doctrine barred an infringement action against the drug store. The court explained the underlying principle in terms commonly invoked in patent first sale cases: the "ultimate question ... is whether or not there has been such a disposition of the copyrighted article that it may fairly be said that the copyright proprietor has received his reward for its use." ${ }^{, 79}$ The court did not address

751909 Copyright Act $\S 41,35$ Stat at 1084 .

76 In the hearings, a member of the ABA's committee on patents and copyright legislation defended the importance of limiting the exclusive distribution right to the first sale by reference to the evils of resale price fixing, as in Bobbs Merrill. 1909 Copyright Act, Arguments on Common-Law Rights as Applied to Copyright, Section 4, H.R. 21592 before the Copyright Subcommittee of the House Committee on Patents, 60th Cong (Jan 20, 1909) (testimony of Robert Parkinson), reprinted in Brylawski and Goldman, eds, 5 Legislative History of the 1909 Copyright Act Part L at 30-34 (cited in note 74).

77 That at least was the uncontradicted interpretation given by Arthur Steuart, chairman of the ABA's committee on patents and copyright legislation, which was instrumental in crafting the 1909 Act. Summarizing the arguments of another ABA committee member, Steuart asserted that $\S 41$ was intended to make clear that the copyright owner cannot limit the sale price of a book "in the absence of privity of contract with the purchaser." Id at 40 (testimony of Arthur Steuart) (emphasis added). Of course, as we learned later from Dr. Miles, a contract to fix prices is unlawful under antitrust law; however, this does not alter the general point about contractual restrictions on use or resale apart from price fixing.

78233 F Supp 881 (ED Pa 1964).

79 Id at 884. 
the question of whether a copyright owner might have enforced such a restriction by means other than an infringement action.

The 1976 Copyright Act, ${ }^{80}$ which reaffirmed the first sale doctrine, ${ }^{81}$ did not add any clarity on this point. As with the 1909 Act, the legislative history indicates that the first sale doctrine as understood by Congress circumscribed only the owner's copyright but did not necessarily preclude the owner from enforcing contractual restrictions on subsequent distribution. That interpretation was affirmed, albeit in dicta, by the Supreme Court's 1998 decision in Quality King Distributors, Inc v L'Anza Research International, Inc, where the Court stressed that its application of the first sale doctrine to imported goods was purely a matter of copyright and did not necessarily affect contractual restrictions.

The emergence of software licensing has brought new salience to this question of contractual avoidance of the first sale doctrine. The practice of licensing computer software began with the birth of the software industry in the 1960s, when software programs were unbundled from the computers and separately marketed. ${ }^{84}$ The earliest programs were actually leased rather than licensed, but leasing proved to be awkward insofar as it entailed periodic payments and was eventually replaced by the current perpetual license instead. ${ }^{85}$ The choice to lease or license software was plainly motivated by a desire to obtain protection that might not be obtainable under copyright or patent law. ${ }^{86}$ Indeed, in the early years it was unclear whether software was protected at all by copyright or patent law, so leasing or licensing was seen as a vehicle for securing contractual protections to supplement or

\footnotetext{
80 Pub L No 94-553, 90 Stat 2541, codified as amended at 17 USC $\$ 101$ et seq (2000).

$81 \quad 17$ USC \& 109(a).

82 See William F. Patry, 2 Copyright Law and Practice 846 (Bureau of National Affairs 1994).

83523 US 135,143 (1998).

84 Initially computer software was integrated into the hardware or was provided by a software services firm. In the late 1960s software service firms began marketing software as a separate product, though the big impetus for marketing software as a separate product came in 1970 when IBM unbundled its hardware and software. See generally Luanne James Johnson, A View from the 1960s: How the Software Industry Began, 20 IEEE Annals of the History of Computing 36 (1998) (describing the history of "unbundling" hardware from software in the 1960s, and the existence of independent software marketing during that era).

85 See id at 38-41 (discussing pitfalls of the equipment lease model and the progression to licensing). IBM, however, originally adopted leasing with periodic payments because it feared that a license with a single payment would look like a sale. Watts Humphrey, Software Unbundling: A Personal Perspective, 24 IEEE Annals of the History of Computing 59, 60 (2002).

86 Humphrey, 24 IEEE Annals of the History of Computing at 60 (cited in note 85) (describing how licensing was implemented to supplement copyright protection, the strength of which was unknown by early software developers). Trade secret protection, of course, was always available, but because it does not protect against reverse engineering, see Restatement (Third) of Unfair Competition $\S 43$ (1993), special contractual restrictions on reverse engineering were needed.
} 
substitute for property right protections. ${ }^{87}$ Of course, the practice of licensing outlived any doubts about the availability of intellectual property protection for software, and the persistence of licensing has engendered a fierce, and often shrill, debate.

Part of the debate concerns the "shrinkwrap" or "clickwrap" form of the license and its enforceability." This part of the debate is only marginally important to the main concerns of this Article, but it calls for some comment. The enforcement question divides into two distinct questions. One is whether a "buyer" (licensee) can be deemed to assent to a contract the terms of which are not fully known to him at the time of purchase (since they are contained in the shrinkwrapped package or in the software itself). ${ }^{91}$ This can be easily solved by calling

87 See Humphrey, 24 IEEE Annals of the History of Computing at 60 (cited in note 85); Johnson, 20 IEEE Annals of the History of Computing at 38-41 (cited in note 84). See also Martin Goetz, Memoirs of a Software Pioneer: Part 2, 24 IEEE Annals of the History of Computing 14, 17-19 (2002) (describing the persistence of uncertainty about copyright and patent protection well into the 1970s).

88 The patentability question was resolved in 1981. See Diamond v Diehr, 450 US 175 (1981) (upholding the patentability of a process for curing synthetic rubber that relied on a computer program). The existence of copyright protection for computer programs was settled in 1982. See Williams Electronics, Inc v Artic International, Inc, 685 F2d 870 (3d Cir 1982) (upholding the copyrightability of object code for a video game as a form of "literary work" under the 1976 Copyright Act). However, software developers remained concerned that neither patent nor copyright would give them the scope of protection they needed. See Goetz, 24 IEEE Annals of the History of Computing at 23 (cited in note 87) (stating that companies sought protection of the "look and feel" as well as protection for business methods).

89 Much of the debate has centered on the Uniform Computer Information Transactions Act (UCITA) designed to provide a contractual framework for software licensing. See, for example, Symposium: Intellectual Property and Contract Law in the Information Age: The Impact of Article $2 B$ of the Uniform Commercial Code on the Future of Information and Commerce, 13 Berkeley Tech L J 809 (1998) (collection of symposium articles discussing the possible impact of Article 2B of the UCC (UCITA)). Although UCITA was adopted in two states, Virginia and Maryland, such has been the fury of opposition to its enactment elsewhere that the National Conference of Commissioners on Uniform State Laws has now abandoned efforts to promote its further adoption. Michael Wanecke, UCITA Drafters Ditch Licensing Act as Ahead of Its Time, Politically DOA, 8 BNA Elec Comm \& L Rep 771 (Aug 13, 2003).

90 See, for example, Mark A. Lemley, Intellectual Property and Shrinkwrap Licenses, $68 \mathrm{~S}$ Cal L Rev 1239, 1248-59, 1283-91 (1995) (discussing judicial enforcement of shrinkwrap licenses and critiquing the application of contract law principles to intellectual property).

91 The case law is divided on the question of whether shrinkwrap/clickwrap licenses are enforceable under the UCC. Compare Step-Saver Data Systems, Inc v Wyse Technology, 939 F2d 91 (3d Cir 1991) (holding that a "limited use license agreement" printed on a package containing computer software did not become part of the sales agreement for the software where it was not assented to at the time the goods were sold, and that under UCC \$ 2.207 (ALI 2002), a material alteration of the agreement does not become part of the agreement without the buyer's express consent); Klocek v Gateway, Inc, 104 F Supp 2d 1332 (D Kan 2000) (stating that shrinkwrap license provisions requiring arbitration do not become part of an agreement merely through the retention or use of the product after the notice of terms), with ProCD, Inc v Zeidenberg, 86 F3d 1447 (7th Cir 1996) (enforcing shrinkwrap licenses under the UCC); i.LAN Systems, Inc v Netscout Service Level Corp, 183 F Supp 2d 328, 337-39 (D Mass 2002) (same). Section 112 of UCITA expressly authorizes shrinkwrap/clickwrap licenses subject to certain conditions, such as the right to return the product if the buyer does not assent to the license terms. Presumably even 
the buyer's attention to the conditions at the time of sale and inviting her to examine them before purchase. This is a fairly standard procedure for obtaining digital products online by means of clickwrap licenses that allow the buyer/licensee to read the terms of the sale/license prior to signifying assent; it would not seem to be very burdensome to replicate this procedure at the checkout counter of Office Depot if notice at the point of sale is considered to be a precondition of enforceability. A second objection is that shrinkwrap licenses are adhesion contracts. This objection goes well beyond shrinkwrap licenses or computer software and implicates practically the entire realm of modern marketing. Most consumer goods are sold on a takeit-or-leave-it basis. We do bargain over some things, of coursenormally high-priced goods where the value of the goods justifies the cost of negotiation. But no one expects to bargain with Wal-Mart over the price of electrical kitchen appliances; and, ceteris paribus, there is no reason to make an exception for information products. ${ }^{93}$ The conventional defense of all standardized dealing is that it saves the transaction costs of individualized bargaining. But standardized adhesion contracts are more than a means of avoiding the costs of individual negotiations; they are a necessary part of the institutional structure of mass-market distribution of most goods. Adhesion contracts not only regulate the contract between seller and buyer, they also organize the authority and responsibility of the seller's agents with respect to the goods being sold. Wal-Mart does not empower its sales clerks to bargain over its merchandise because it would alter radically the way it markets goods. By the same token can one imagine manufacturers al-

if the shrinkwrap/clickwrap license is enforced against those who break open the package or click their assent to the terms, it cannot be enforced as a contract against persons who buy the product and resell without breaking open the package. See SoftMan Products Co v Adobe Systems Inc, 171 F Supp 2d 1075, 1088 (CD Cal 2001) (holding that the defendant was not bound by the end user license agreement because it never loaded the software, and therefore never was required to assent to its terms of use).

92 Some retailers apparently refuse to allow a return of software where the shrinkwrap package has been opened. A class action suit has been filed against Microsoft and various retailers claiming a conspiracy to defraud the public on the grounds that the retailers have refused to accept return of opened software packages by customers who refuse to accept the license terms. See Complaint for Consumer Damages, Rescission and Unlawful and Unfair Business Practices, Baker v Microsoft, Inc, Civil Action No 030612 (Super Ct Cal filed Feb 7, 2003), online at http://www.techfirm.com/Baker-Final.pdf (visited Aug 5, 2004). The claim doesn't change my point that this problem could be easily made to disappear if Microsoft and other software vendors insisted that retailers disclose these license terms at the point of sale. They could easily be persuaded to do so by making this a condition of the enforcement of the shrinkwrap license terms.

93 The ceteris that is paribus here is the price of the product. As the underlying value of the transaction increases one would expect to see a shift away from standardized, take-it-or-leave-it transactions since the higher value at stake can cover the cost of individualized dealing. This concession does not alter my point about shrinkwrap licenses, however, since the price of most consumer software programs is no greater than the price of most electrical kitchen appliances. 
lowing downstream distributors to alter the nature of the good that is being sold by individualized bargains over conditions like warranties or quality assurances that bind the manufacturer? This has been described as an institutional "rigidity," the implied suggestion being that it is somehow a defect of modern marketing-but it is quaint to think about replacing standardized mass marketing with the methods of a Turkish bazaar. ${ }^{95}$ assume academic and judicial critics of shrinkwrap licenses understand this economic reality, so I take their real objection to be not to standardization as such but to the substantive restraints that the licenses impose. ${ }^{.6}$

This latter objection quickly translates into an argument that the licenses are being used to avoid limitations that copyright law places on the owner's rights or even to create property-like protection for material that is not copyrightable. The claim of avoidance assumes, of course, that licensing seeks to create a form of protection that comes within the scope of the copyright's exclusive domain and hence should be deemed preempted by $\S 301$ of the Copyright Act. ${ }^{98}$ In ProCD, Inc

94 Todd D. Rakoff, Contracts of Adhesion: An Essay in Reconstruction, 96 Harv L Rev 1173, 1224 (1983) ("Firms do not want to negotiate individualized contracts, because doing so entails bearing not only the costs of the particular negotiations, but also the economic and institutional costs of modifying an organizational structure geared to the standardized terms.").

95 The Turkish bazaar reference must be understood as a very limited model even in Turkey. One would no more bargain over the price of a toaster in an Istanbul department store than in an Indianapolis Wal-Mart. In all countries with modern markets, bargain transactions for consumer goods are generally limited to nonstandard products or high-value products where the costs of individualized bargaining are a small part of the value involved.

96 The standardized character of contracts may be relevant to other public policy questions, such as whether the restrictions contained in them restrain trade-a question I deal with in Part III.A. However, the vice is not standardization as such, but standardization as a reflection of market power. Standardized contracting does not in and of itself constitute a restraint of trade; if it did, most of the American economy would violate antitrust law.

97 See Lemley, 68 S Cal L Rev at 1255-60, 1263-84 (cited in note 90) (arguing that shrinkwrap licenses-governed by state contract law-should be preempted by federal intellectual property law, and should also expand intellectual property protection beyond the boundaries set by Congress). Criticism of conditional licensing has focused on the copyright conflicts, but basically the same conflicts arise in the case of patented software.

9817 USC $\$ 301$ (2000). A small qualification is required here. In the case of restrictions on post-sale transfer that implicate the first sale doctrine there are two distinct questions that tend to be conflated. One is the question of whether the first sale doctrine applies to end user licenses insofar as they do not transfer title to the copyrighted article, which is the predicate of the first sale doctrine. The other is whether one can pursue contract remedies that provide protection equivalent to that provided by copyright. The distinction can be important. For instance, if a court recognizes that the license is not tantamount to a sale, then a restriction on post-sale transfer can be enforced under the copyright law (as an infringement of the copyright owner's distribution right), and the question of contract enforcement, and of preemption, need not be addressed. Courts have differed as to whether an end user license is such a sale. Compare Microsoft Corp v Harmony Computers \& Electronics, Inc, 846 F Supp 208, 212-13 (ED NY 1994) (finding the first sale doctrine not applicable because software was licensed, not sold, to distributors); Adobe Systems Inc v One Stop Micro, Inc, 84 F Supp 2d 1086, 1092 (ND Cal 2000) (same); Microsofi Corp v Software Wholesale Club, Inc, 129 F Supp 2d 995, 1007-08 (SD Tex 2000) (same), 
$v$ Zeidenberg ${ }^{99}$ the Seventh Circuit, in a controversial opinion by Judge Easterbrook, rejected preemption on the grounds that the Copyright Act's preemption is expressly limited to forms of legal protection that are "equivalent" to copyright. Reasoning that this implied some kind of property rights protection, and that contract rights are not property rights but a form of "private ordering," the court held that contracts fell outside the Act's zone of preemption. ${ }^{100}$

Critics of ProCD-and there are a lot of them ${ }^{101}$ - have argued that it undermines the balance that copyright law draws between the copyright owner's exclusionary rights on the one hand and the public's access rights on the other. By use of contractual licensing restrictions, the owner can effectively create a separate legal order for intellectual property that is independent of and even inconsistent with that prescribed by Congress. ${ }^{102}$ The court's distinction between so-called private ordering by contract and public ordering by means of property rights is a slippery one at best and may be illusory. After all, in the common law both contract and property rights are normally considered private ordering in the sense that the rights are typically created by private transactions. My property rights in Blackacre, my Honda, and my Swiss Army knife are all derived from private ordering: I bought each of them in the private market. Yet the Copyright Act of 1976 unmistakably preempts common law property rights where they replicate the property rights falling within the scope of copyright. ${ }^{103}$ Simply as a matter of legislative interpretation, therefore, a categorical

with SofiMan Products Co v Adobe Systems Inc, 171 F Supp 2d 1075, 1083-86 (CD Cal 2001) (finding that a purported license transaction was, in reality, a sale, hence the first sale doctrine applied); Novell, Inc v Network Trade Center, Inc, 25 F Supp 2d 1218, 1230 (D Utah 1997) (same), vacd, 187 FRD 657 (D Utah 1999). If, of course, a license is treated as a sale, or if rights other than the distribution right are involved, or if (as in ProCD, see notes 99-106 and accompanying text) there is no copyright but the work being protected is of a kind that falls within the domain of copyright law, then the issues of contract enforcement and preemption arise.

9986 F3d 1447 (7th Cir 1996).

100 Id at 1454.

101 Critics have condemned the decision both for its holding that shrinkwrap licenses are enforceable as contracts and its holding that license contracts are not preempted by the Copyright Act. See Mark A. Lemley, Beyond Preemption: The Law and Policy of Intellectual Property Licensing, 87 Cal L Rev 111, 120 n 20 (1999) (collecting commentary).

102 See Charles R. McManis, The Privatization (or "Shrink-Wrapping") of American Copyright Law, 87 Cal L Rev 173, 178-84 (1999) (arguing that decisions like ProCD could allow copyright holders to expand the scope of copyright protection and "undermine the federal copyright bargain").

103 The conventional test of whether a common law property right replicates (in the language of 17 USC $\S 301$, is "equivalent to") copyright is whether it contains an "extra element" that "changes the nature of the action so that it is qualitatively different from the copyright infringement claim." See, for example, Mayer v Josiah Wedgewood \& Sons, Ltd, 601 F Supp 1523, 1535 (SD NY 1985) (finding both common law conversion and appropriation claims preempted by the Copyright Act). 
exclusion from the preemptive effect of copyright for all contractual restrictions is unwarranted.

As to the conventional distinction based on the notion that contract rights are enforceable only between consenting parties and property rights are enforceable against the world, this distinction is blurred if not erased completely in the context of computer software where the license can be embedded in the software itself and is configured to require each new user to agree to its terms before the program can be run. ${ }^{104}$ By these means, the software license becomes virtually identical to a running servitude and can be regarded, like other servitudes, as a form of property right. ${ }^{1.5}$ No matter how one labels the license restrictions, though, the underlying policy issue remains the same: to what extent should the owner of a limited intellectual property right be permitted to create contractual "servitudes" that alter the allocation of property rights established by the intellectual property regime?

There is no good reason to think that the resolution of this issue must be the same for all license conditions. Judge Easterbrook's private ordering argument logically seems to imply that contractual arrangements are categorically not preempted by $\S 301$, but it is noteworthy that even this champion of private ordering stopped short of that conclusion and allowed for the possibility that "some applications of the law of contract could interfere with the attainment of national objectives and therefore come within the domain of $\S 301(\mathrm{a}) .{ }^{, 106} \mathrm{Al}-$ though he did not further elaborate on what kinds of contractual restrictions might interfere with national objectives, what is important is that he left the way open for inquiry into the effects of particular restrictions on the underlying copyright policy.

104 In such cases, Judge Easterbrook's statement in ProCD that a person who found a copy of plaintiff's software would not be bound by its terms, 86 F3d at 1454, is misleading since the minute the finder attempted to load the program it would require his assent as a condition of running the program.

105 See, for example, Lemley, 87 Cal L Rev at 120-21 (cited in note 101); Margaret Jane Radin and R. Polk Wagner, The Myth of Private Ordering: Rediscovering Legal Realism in Cyberspace, 73 Chi Kent L Rev 1295, 1312-13 (1998). Quite apart from whether the license is embedded in the software requiring the user to manifest assent before using the program, it has been argued that an industrywide adoption of license terms could be a basis for preempting license restrictions as "private legislation." See Robert P. Merges, The End of Friction? Property Rights and Contract in the "Newtonian" World of On-line Commerce, 12 Berkeley Tech L J 115, 126 (1997). See also Maureen A. O'Rourke, Drawing the Boundary between Copyright and Contract: Copyright Preemption of Software License Terms, 45 Duke L J 479, 541-55 (1995) (arguing that preemption should depend on whether the vendor has market power or the licenses are bargained for). I doubt that phrases like "private legislation" are helpful in thinking clearly about preemption, but I agree that a widespread acceptance of a practice is relevant to whether a particular set of restrictions conflicts with public policy, whether that policy is located in copyright or other relevant law (including contract law itself).

106 ProCD,86 F3d at 1455. 
Common sense suggests that the various restrictions contained in software license agreements do not have equally important implications for copyright policy. Everyone agrees that copyright policy seeks to balance private exclusionary rights against public rights of access. The promotion of "Progress of Science and useful Arts" proclaimed constitutional objective of copyright depends not simply on protecting authorial incentives, but also on providing public access to the stuff of which new creations are made, which entails some degree of borrowing. ${ }^{108}$ However, some elements of copyright policy are more important to that balance than others. Fair use has always been an important component of that balance-though it is still in the realm of reasonable debate just how important. ${ }^{109}$ By contrast the first sale doctrine is a relatively late addition to copyright law, and one whose justification is still underdeveloped despite a century of mechanical recitation. " (I say "century" to mark the lifetime of the first

107 US Const Art $1, \S 8, \mathrm{cl} 8$.

108 See Sony Corp of America v Universal City Studios, Inc, 464 US 417, 477 (1984) (Blackmun dissenting) (finding that "the fair use doctrine plays a crucial role" in balancing the rights of original authors and others seeking access for their own creative projects); Jessica Litman, The Public Domain, 39 Emory L J 965, 967 (1990) ("[P]ublic domain is the law's primary safeguard of the raw material that makes authorship possible."); William M. Landes and Richard A. Posner, An Economic Analysis of Copyright Law, $18 \mathrm{~J}$ Legal Stud 325, 332 (1989) (stressing the need for some privileged access to currently protected works of others in order to avoid costly alternative forms of borrowing).

109 One measure of importance is given by recurrent arguments that fair use has a constitutional status. In Suntrust Bank v Houghton Mifflin Co, 252 F3d 1165, 1166 (11th Cir 2001) (reversing the district court's grant of an injunction in favor of the owners of the copyright in Gone With the Wind against publication of The Wind Done Gone as an unlawful prior restraint), the court by implication held that a fair use privilege was required by the First Amendment. However, Suntrust is exceptional in its explicit reliance on the First Amendment; virtually all other cases have followed the Supreme Court's lead in Harper \& Row, Publishers, Inc $v$ Nation Enterprises, 471 US 539, 560 (1985), in holding that First Amendment principles are incorporated into the structure of copyright law, thereby finessing the question of whether any of the current elements of copyright law are constitutionally required. See generally Neil Weinstock Netanel, $L o$ cating Copyright within the First Amendment Skein, 54 Stan L Rev 1 (2001).

110 David Rice makes a contrary claim concerning the importance of the first sale doctrine, arguing that the "Copyright Act balances the competing interests of copyright and competition. The first sale doctrine operates precisely at that balance." David A. Rice, Licensing the Use of Computer Program Copies and the Copyright Act First Sale Doctrine, 30 Jurimet J 157, 182 (1990). This claim is misleading as a generalization about copyright law and simply wrong as a statement about the first sale doctrine. As to copyright law generally, the famous "balance" that copyright law seeks to achieve is between private claims of control and public claims of access. This balance certainly can affect competition (among "original" authors and "borrowing" authors), but it is misleading to suppose that economic competition is what the balance is necessarily or even primarily about. As to the first sale doctrine, the assumption that competition requires that an owner's rights be exhausted after the first transfer of title is belied by the fact that antitrust law allows upstream sellers to impose distribution restrictions on downstream sellersas I point out below. Perhaps Rice had in mind the fact that the first sale doctrine originated with attempts to impose resale price restrictions that are forbidden by antitrust. However, as I shall argue below, the antitrust proscription on resale price fixing is today controversial, and in any case exceptional. See text accompanying notes 188-95. 
sale doctrine, but to the extent that doctrine is derived from the common law policy against restraints on alienability, we could trace it back several centuries - which makes all the more remarkable the absence of a coherent principle to support it.)

\section{PRINCIPLE AND PURPOSE}

As noted, hostility to restraints on the use or transfer of personal property has been commonly grounded in the common law policy against restraints on alienation. In intellectual property cases, the alienability policy is also associated with the competition policy against restraints on trade. Although alienability and restraint of trade issues are sometimes conflated, they reflect distinctive policies and require separate analyses. With a few exceptions the analysis of these two policies can be applied both to common law and intellectual property.

\section{A. Alienability and Standardization}

1. Formalism as information.

The common law has invalidated restraints on alienation of property from time out of mind. ${ }^{111}$ The pedigree of the rule may account for the paucity of reasons for it. In its formative role-as a reaction to feudal lords restricting the free alienation of property ${ }^{112}-$ the rule scarcely required explanation. But with the feudal system out of the way one might expect some explanation for refusing to allow ordinary property owners to dispose of their property on such terms as they choose. As often as not the "reason" given is simply that it cannot be done because the right of alienability is inherent in the property right being transferred. Coke's formulation of the rule more than three centuries ago explained that when an owner of property sells or gives "his whole interest" in the property he cannot at the same time prohibit its further alienation "because his whole interest and propertie is out of him, so as he hath no possibilitie of a reverter, and it is against trade and traffique and bargaining and contracting between man and

111 See John Chipman Gray, Restraints on the Alienation of Property 2-3, 9-10 (Boston Book 2d ed 1895) (citing cases from as early as the fourteenth century holding restraints on alienability to be void). Conventional doctrine distinguishes various types of restraints according to whether they are disabling restraints, involve forfeiture, or are based on promises by a transferee, though the distinctions reflect more a scholastic formalism than a practical application of policy. On the various classifications and the rationales behind them, see Restatement (Second) of Property (Donative Transfers) \& 3 (1981).

112 The "modern" policy is generally traced to the Statute Quia Emptores, 18 Edw I ch 1 (1290), forbidding tenants from subinfeudation of fee simple interests but allowing them in return to transfer their entire interest without the landlord's consent. See Gray, Restraints on the Alienation of Property at 2-3, 8-11 (cited in note 111). 
man." ${ }^{113}$ Coke's locution (as well as his spelling) is archaic, yet, astoundingly, the circular style of reasoning can still be found in contemporary statements that explain that restraints on alienability are "repugnant to the deed."

As Percy Bordwell pointed out a long time ago, the repugnancy argument is question-begging since it assumes without argument that free alienability is a necessary element of the property right that must pass with every conveyance. ${ }^{\text {ys }}$ Of course, the repugnancy notion was associated with the nature of a fee simple estate in land and with the idea that such an estate, being the most complete estate known to property law, must contain the right to transfer. It is a bit redolent of Anselm's ontological proof of the existence of God, which goes something like this: God is something than which nothing more perfect can be conceived, and this necessarily implies that God must exist, otherwise we should be able to conceive of something more perfect (something with God-like attributes that does exist); therefore God exists. The obvious rejoinder to this kind of reasoning-I will limit myself to fee simple estates and ignore the theological question-is simply to say that whenever we see a deed that purports to restrict the alienability of a fee simple estate, it simply cannot be a fee simple; it must be something else - a "fee complex" perhaps. Quod erat demonstrandum, as Anselm might have said. This kind of reasoning will not get us very far unless we get beyond the semantics by postulating a principle of substantive limitation on the kinds of property rights that should be allowed to exist. So understood, the repugnancy argument becomes a kind of numerus clausus principle, that property rights come in only limited forms and cannot be altered to suit the owner's wishes. On this notion property not only wants to be free, it wants to be standardized as well.

113 Edward Coke, 2 The First Part of the Institutes of the Laws of England $\$ 360$ (Garland 1979 , reprint of $1832 \mathrm{ed}$, original 1628).

114 See, for example, Williams $v$ Williams, 73 SW3d 376, 379-80 (Tex App 2002) (stating that "the right of alienation is an inherent and inseparable quality of an estate of fee simple"); Riste $v$ Eastern Washington Bible Camp, Inc, 25 Wash App 299, 605 P2d 1294, 1295 (1980) (noting that "a clause in a deed prohibiting the grantee from conveying land to another without the approval of the grantor ... is void as repugnant to the nature of an estate in fee").

115 Percy Bordwell, Alienability and Perpetuities II, 23 Iowa L Rev 1,14 (1937) (arguing that the repugnancy argument begs the question because "[b]y definition it makes alienability a characteristic of the fee simple and then rejects general restraints as inconsistent with the definition"). Gregory Alexander aptly notes that this repugnancy concept is possible only because the ancient legal mind that conceived it could sharply distinguish between the owner's freedom to dispose of property and his lack of power to define what property is. Gregory S. Alexander, The Dead Hand and the Law of Trusts in the Nineteenth Century, 37 Stan L Rev 1189, 1225-26 (1985) (discussing generally the problem that "individual freedom to dispose of consolidated bundles of rights cannot simultaneously be allowed and fully maintained").

116 Anselm, Monologion and Proslogion 99-101 (Hackett 1995) (Thomas Williams, trans). 
The numerus clausus principle is a civil law concept that has never been explicitly acknowledged by the common law, at least in America, but Thomas Merrill and Henry Smith have provocatively argued that the principle is in fact part of the common law's deep structure. ${ }^{117}$ Merrill and Smith argue that the principle is not an empty formalism but an efficient means of standardizing property interests, which avoids information cost externalities arising from highly variable (idiosyncratic) property interests. Their argument goes far beyond the alienability issue considered here ${ }^{118}$ but insofar as their argument does defend the law's general hostility to chattel servitudes, I need to say something about it.

Merrill and Smith find evidence of a numerus clausus principle in several doctrinal venues, but most notably they find it in the various classifications of property - for instance, the classifications of land estates, concurrent interests, nonpossessory interests, and leaseholdsand in the tendency of courts to shoehorn interests in land into these molds. ${ }^{119}$ It is hard to know what to make of this evidence since, as Merrill and Smith themselves note, courts generally purport to be involved in a task of interpreting the intent of the parties in cases of ambiguity. Using conventional frameworks is an unexceptionable interpretive move. Perhaps the move reflects the power of formalism, but it does not necessarily reflect any deep commitment of principle to it. ${ }^{120}$ Of course, there are cases where particular interests have been

117 Thomas W. Merrill and Henry E. Smith, Optimal Standardization in the Law of Property: The Numerus Clausus Principle, 110 Yale L J 1,9-23 (2000) (concluding that numerus clausus is a fact about the way property operates that is "so patent and obvious, so deeply entrenched, that it is rarely commented upon"). For an earlier treatment of numerus clausus, see Bernard Rudden, Economic Theory v. Property Law: The Numerus Clausus Problem, in John Eekelaar and John Bell, eds, Oxford Essays in Jurisprudence: Third Series 239 (Clarendon 1987). Rudden also noted that the numerus clausus principle had largely escaped notice by commentators. Unlike Merrill and Smith, Rudden could find no convincing economic justification for the principle.

118 For an extended critique of the Merrill-Smith thesis, see Hansmann and Kraakman, $31 \mathrm{~J}$ Legal Stud S373 (cited in note 34) (arguing that the limit on the forms property rights can take serves not to standardize rights but to aid verification of the ownership of property rights for conveyance).

119 Merrill and Smith, 110 Yale $\mathrm{L} J$ at 12-20 (cited in note 117).

120 One of the more interesting examples used by Merrill and Smith is the case of standardizing leaseholds by construing a "lease for life" to fit within either or two of the standardized property classifications, a life estate or a tenancy at will. Id at 22. Note that labeling a "lease for life" a "life estate" doesn't really change any feature of the interest created: it remains a lease insofar as possession is conditioned on payment of rent. See, for example, Collins v Shanahan, 34 Colo App 82, 523 P2d 999, 1003-04 (1974) (declaring the lease for life a life estate, but upholding the termination of the grantee's interest for nonpayment of rents). In all events their particular example of lease standardization turns out to be a poor one because courts have enforced leases that don't fit the standard four forms-notably leases for indefinite duration, Philpot $v$ Fields, 633 SW2d 546, 548 (Tex App 1982) (allowing a lease for twenty years and as long thereafter as the land was used for specified purposes, because "[a]lthough there is no definite ending date[, the end] is tied to the cessation of the use of the land for certain definitely ascertainable purposes"), and even leases in perpetuity, Camerlo v Howard Johnson Co, 710 F2d 987, 988, 
forbidden for specific reasons of public policy, such as the prohibition against fee tail estates, or the prohibition against remotely vesting contingent future interests. Merrill and Smith rightly do not claim these as examples, for they do not instate a general principle of property law. Such limitations merely seek to advance a specific policy interest -in these two cases, the policy against restraints on alienability. ${ }^{12}$

The mere fact that property law has a habit of classifying different property interests proves nothing. The law often classifies interests simply for analytical convenience with no purpose of making them functionally important. Indeed, it is famously true of property law that it retains many classifications that serve no analytical or functional purpose whatsoever - as anyone who has grappled with the distinction between shifting and springing executory interests will appreciate. Even if the classifications are prescriptive, one needs to know whether the boundaries of the classification are drawn so tightly that they foreclose significant variation. Consider, for example, servitude law; Merrill and Smith cite it as an example of standardization based on the fact that one can fit virtually all servitudes into four basic categories (real covenants, equitable servitudes, easements, and profits). ${ }^{122}$ But these general classifications permit a wide range of variable property rights. ${ }^{123}$ Because of servitudes, a fee simple interest today is rarely simple; deed-restricted neighborhoods are ubiquitous,

991-92 (3d Cir 1983) (upholding a lease of ninety-nine years, "renewable thereafter forever, at the same rental as the ninety-ninth year").

121 This was the primary legal rationale for New York's eventual prohibition of the "lease in fee" that was used in the Hudson River Valley in the eighteenth and nineteenth centuries. The lease in fee combined the features of a fee simple (perpetual duration and inheritability) and a lease (annual rents, in perpetuity, plus a quarter share of the sale price if transferred by the lessee). A state constitutional amendment in 1846 abolished perpetual leases in agricultural land, but this did not affect existing leases, which continued to be enforced for another two decades. See, for example, Van Rensselaer v Barringer, 39 NY 9, 13-14 (1868) (upholding a perpetual lease). But see De Peyster v Michael, 6 NY 467, 505 (1852) (holding a lease in fee to be void as "repugnant to the estate granted" based on both English common law following the statute quia emptores and similar developments in state law). Anent the numerus clausus issue, what is most noteworthy about the lease in fee is that, despite its unusual form, the New York courts repeatedly affirmed its use, essentially on freedom of contract grounds. Its eventual demise was more a product of the political controversy generated by the Hudson River Valley patroons' continued control of vast tracts of land than legal objections, but to the extent legal objections were important they were not grounded in the formal peculiarity of the lease in fee. The history of the legal and political controversy surrounding the lease in fee and the Hudson River manors generally is ably recounted in Charles W. McCurdy, The Anti-rent Era in New York Law and Politics: 18391865 (North Carolina 2001), and Reeve Huston, Land and Freedom: Rural Society, Popular Protest, and Party Politics in Antebellum New York (Oxford 2000).

122 Merrill and Smith, 110 Yale L J at 16 (cited in note 117).

123 See Hansmann and Kraakman, $31 \mathrm{~J}$ Legal Stud at S398-S402 (cited in note 34). Hansmann and Kraakman observe that the law does sometimes create what they call "verification" rules that serve a kind of notice function to protect the interests of third parties who encounter unexpected property right claims. 
and they are not standardized (even though they are subject to various common law and statutory limitations).

The example of personal property is particularly interesting; Merrill and Smith note, as did Chafee, that personal property servitudes seem not to be permitted, but they concede that the authority in support of that conclusion is both limited and ambiguous. ${ }^{124}$ In fact, as we have seen, courts have recognized such servitudes on occasion, sometimes explicitly and sometimes in the guise of other doctrinal categories such as tortious interference with contract. ${ }^{125}$ Moreover, cases disallowing servitude restrictions on personal property have done so not because they deviate from a prescribed form of property or property transaction but because they run afoul of some exogenous public policy, such as that against alienability restraints or restraint of trade.

Merrill and Smith's positive claim that a numerus clausus principle underlies the common law is unpersuasive, but that does not necessarily undermine their normative claim, which deserves separate consideration. Their central argument for limiting the forms of property is to minimize transaction costs by standardizing the key legal attributes of property rights. Creating idiosyncratic property interests increases the information costs associated with the property. They illustrate with a fanciful hypothetical of a watch owner who seeks to transfer a time-share interest in the watch. ${ }^{126}$ The possibility of such an idiosyncratic interest creates special information costs for all those who want to purchase a watch insofar as they will have to make a special inquiry into the nature of the interest they are purchasing. This is not a problem between the original transacting parties, since the costs of such an idiosyncratic interest are fully internalized in the original bargain. The time-share interest may be so idiosyncratic as to make the watch commercially valueless - who wants to own the watch for only part of the week? But this will be fully reflected in the terms of the original exchange. By the same token any devaluation of the watch in the hands of successors will be reflected in the original transaction. The original parties might not reasonably assess the long-term impact of their odd transaction on the value of the watch, but the law does not generally interfere with consensual transactions simply on the grounds that the parties apply an incorrect discount for future effects. ${ }^{127}$ The real problem, Merrill and Smith explain, is that the crea-

124 Merrill and Smith, 110 Yale L J at 18 (cited in note 117).

125 See note 34.

126 Merrill and Smith, 110 Yale L J at 27-34.

127 Some have argued that the law ought to intervene on this account. Stewart Sterk, among others, has argued for limiting the duration of land servitudes because people are often unable to make adequate assessment of future contingencies. Stewart E. Sterk, Foresight and the Law of 
tion of idiosyncratic property interests creates an externality for all others who deal in this kind of property because they will now have to incur costs to ensure that they are receiving the full property rights they expect. ${ }^{120}$

The argument is theoretically interesting, but unconvincing. All else being equal, property rights should be designed to minimize transaction costs. This includes taking into account the information needs of what Smith elsewhere calls the "audiences" to whom the property rights are addressed. ${ }^{129}$ However, as he points out, these "audiences" vary greatly and each has its own distinctive information needs. ${ }^{130}$ Those who merely want to avoid interfering with a property right (a common law trespass or a copyright infringement) will have information needs different from those who want to enter into transactions with the owner (by means of, say, a purchase or a license to use). It is difficult to see how this variety of information needs gets translated into a need for a limited number of standardized forms of property à la the numerus clausus principle. In all events it is hard to see how this principle can be reconciled with the need to shape property to serve the varying needs of both owners and "audiences." For instance, even if estates in land are formally confined to certain categories, great variety can be created within those categories by deed conditions and servitudes. ${ }^{131}$ Conditional estates are limited by such doctrines as the policy against restraints on alienability, and the variety of permanent servitudes has been traditionally limited somewhat by the "touch and concern" doctrine. ${ }^{132}$ As a practical matter, though,

Servitudes, 73 Cornell L Rev 956, 958-61 (1988) (criticizing the claim that individuals are better than external decisionmakers at weighing their own present interests against their future interests). While there might be exceptional occasions for such intervention, I think the law could not adopt such a view as a matter of general principle without seriously disrupting private choicesnot to mention introducing a new type of contingency into the enforcement of legal rights. See Glen O. Robinson, Explaining Contingent Rights: The Puzzle of "Obsolete" Covenants, 91 Colum L Rev 546, 564-67 (1991).

128 Merrill and Smith, 110 Yale L J at 31-34 (cited in note 117).

129 See Henry E. Smith, The Language of Property: Form, Context, and Audience, 55 Stan L Rev 1105, 1108 (2003) (understanding "audiences" of property rights as "those under a duty to respect rights[,] those wishing to acquire rights, [and] those expected to enforce rights").

130 Id at 1139-48. The importance of distinguishing the different audiences is nicely developed in the context of patent and copyright by Clarisa Long, Information Costs in Patent and Copyright, 90 Va L Rev 465, 489-95 (2004) (examining why the law provides more than one form of intellectual property rights, why there are differences between the structures of patent and copyright forms, and what determines the optimal structure of each form).

131 See Rudden, Economic Theory v. Property Law at 255-56, 260 (cited in note 117) (noting that property owners have ways of circumventing standardized forms through devices such as running covenants).

132 Hansmann and Kraakman, $31 \mathrm{~J}$ Legal Stud at S402 (cited in note 34), cite the touch and concern doctrine as an example of a verification rule designed to protect remote purchasers of property against idiosyncratic ("personal" in the standard argot) covenants. Even assuming the Restatement is incorrect in declaring the doctrine to be "superseded," see note 36, it is rare to 
the range of variation in traditional property rights is such that additional standardization can do very little work.

Within the existing property rights structure the principal constraint on the ability of property owners to carve out idiosyncratic property interests is not legal but economic. Merrill and Smith's watch time-share example unintentionally illustrates the point. Who would buy such an interest? No doubt property owners often have idiosyncratic preferences, and it is precisely the purpose of property law to enforce those preferences (within limits). But property law has neither the purpose nor the power to create a market for idiosyncratic property interests. Earlier I suggested that common law personal property servitudes were like a liger - a zoo curiosity that, being sterile, cannot reproduce. As with ligers so with watch time-shares: if the law allowed the creation of time-share interests in watches, it would have no more effect on the market for watches than releasing a sterile liger from the zoo into the wild would have on the gene pool of feline predators.

Assume nevertheless that some idiosyncratic property interests might have economic significance-enough to survive in the wild market; it is still doubtful that recognition of those interests creates significant information costs over and above those commonly incurred in the market. Granted, when I buy a watch I assume that I am getting a full title rather than a Monday-only time-share and am therefore not likely even to inquire into the nature of the title being transferred. Moreover, the rational buyer will invest in information about a good (including information about the rights associated with it) only up to the point where marginal gains equal marginal cost. For low-valued goods this investment would be very low. However, this at most argues for the simple expedient of requiring the seller to give the buyer notice of any limitations or conditions on the title of the property being transferred. ${ }^{133}$ Merrill and Smith insist that notice does not solve the problem because the costs are incurred by market participants generally, not just those engaged in a particular transaction. ${ }^{134}$ What they overlook is the fact that if every buyer must be given specific notice of any deviation from the baseline of full title transfer, the information

encounter a covenant that does not in fact touch and concern the land, which suggests that the verification purpose of the rule is either not necessary or not doing any real work.

133 In most real property settings the notice issue is resolved by the fact that the restriction is either part of the buyer's deed or part of an earlier deed of which the buyer has constructive notice under the recording system. In cases where the restriction is not expressed in the deed (or a deed within the chain of title that conveys constructive notice), courts may accept other forms of notice. See, for example, William B. Stoebuck and Dale A. Whitman, The Law of Property $\S 8.28$ at $500-01$ (West $3 \mathrm{~d}$ ed 2000 ). In all of the personal property servitude cases discussed above the court required notice, which has been an intrinsic element of equitable servitude law since Tulk v Moxhay, 41 Eng Rep 1143 (Ch 1848).

134 Merrill and Smith, 110 Yale $\mathrm{L} J$ at $43-44$ (cited in note 117). 
cost problem is solved; there is no externality. A legally required notice has the same effect of internalizing information costs as a legal guarantee of formal title under a numerus clausus principle.

In fact the information cost problem will be solved in most cases even without a legal rule requiring notice. The problem arises in the first place because the restrictions on use are so idiosyncratic as to put the buyer off notice. A full title interest in watches is assumed not because the law so requires but because that is the invariant market norm. If that norm were to change, buyers would simply shift the information cost back on the seller by insisting on a title certificate disclosing and warranting the exact title being conveyed ${ }^{135}$ This might increase the cost of marketing the good. However, as long as the increased cost is internalized to the seller, the cost is no more a matter of economic or legal concern than any other aspect of a seller's business strategy. If Timex decided to market its watches exclusively through high-end jewelry stores, we might think this an odd way to market an inexpensive watch, but we would also think it was something that the market could regulate quite adequately without the law's assistance.

The information costs associated with property rights are similar to those associated with the physical attributes of the good. Some physical attributes are transparent in ways that the rights to the good are not, but many of the most important attributes are not observable. Merely looking at a watch will not tell you whether, in the words of the old Timex commercial, "it takes a licking and keeps on ticking." To learn about performance a buyer must incur additional information costs. Those costs can be reduced, of course, through a combination of market mechanisms (reliance on brand names, seller reputation, and so on) and legal rules-most notably implied warranties of quality. ${ }^{136}$ However, the law does not forbid the transaction nor seek to standardize the terms of trade on that account, even though there could be significant externalities caused by the presence of asymmetric information about watch quality - as the well-known "lemons" problem illustrates. ${ }^{137}$ The same information cost problem Merrill and Smith imagine with the selling of time-share interests in watches is created

135 Section 2-312 of the UCC creates an implied warranty of "good" title but does not specify the interests conveyed by the title. However, a description of the interests conveyed would entail trivial cost.

136 See, for example, id $\S \S 2-314,2-315$ (creating implied warranties of, respectively, merchantability and fitness for purpose).

137 See, for example, George A. Akerlof, The Market for "Lemons": Quality Uncertainty and the Market Mechanism, 84 Q J Econ 488 (1970) (stating that the "lemons" problem involves a reduction in the average quality of goods in a market as a result of prospective buyers using some market statistic to judge the quality of the relevant goods, which in turn gives incentive for sellers to market poor-quality goods). 
by selling different kinds of watches. A person shopping for watches incurs information costs in evaluating the different features of watches (What is the lifetime of a stretch band?) or different brands (Who really makes "Guess" watches?). We could remove those costs the way Henry Ford removed uncertainty about the color of his automobiles by making them all black, ${ }^{138}$ but it hardly seems warranted in the name of transactional efficiency.

No doubt Merrill and Smith would object to the analogy by pointing out that they want to simplify market transactions, not destroy market choices, but they provide no practical or principled basis for distinguishing between the two. All variation in the market, whether it involves variation in the rights or in physical attributes of traded goods to which the rights attach, creates information costs. It is not obvious why we should think the costs associated with one variation are different from the costs associated with the other.

\section{Alienability and commerce.}

Merrill and Smith's argument on behalf of designating property according to fixed characteristics is unconvincing both as a positive and a normative account of property law. The kinds of fixed classifications they defend in the interest of efficiency invariably give way to modifications designed to accommodate the need for more flexible arrangements of rights and obligations. Of course, the fact that the law allows parties to redefine property rights in new ways does not mean there are no restrictions on their doing so. Even if the rule against restraints on alienability is not compelled by some abstract principle of numerus clauses, it might be supported by a more particularized public policy. That in fact has long been the conventional explanation of the rule. Even such a traditionalist as John Chipman Gray recognized that the reason for the rule was not some abstract principle of repugnancy to the norms of property classification but simple "public policy.",130

Unfortunately, the invocation of public policy often proves to be as much a conversation stopper as the invocation of formalism. In an entire book on the subject Gray gave scarcely a hint as to what that public policy was in the case of restraints on alienation. ${ }^{140}$ Today we are

138 Ford once quipped: "Any customer can have a car painted any colour that he wants so long as it is black." Henry Ford, My Life and Work 72 (Doubleday 1923).

139 Gray, Restraints on the Alienation of Property at 11 (cited in note 111) ("In truth, the rule [against restraints on alienability] seems not to allow nor call for any reason except public policy.").

140 The closest Gray got to considering public policy was in his prefatory discussion of court decisions allowing the creation of spendthrift trusts, which he condemned as "weakening of the moral sense, of the feeling of imperative duty to use all the money that a man can control for the payment of his debts." Id at vii. Whatever the vice of spendthrift trusts, it seems merely quaint today to think that the policy against restraints on alienation is needed in order to strengthen the 
apt to find an explanation in the commercial needs of a market economy. Coke himself alluded to the needs of trade and commerce, though without elaboration. ${ }^{141}$ The modern elaboration of those needs is typically stated in terms of efficient use of resources-property must be free to seek its highest valued use in order to prevent social waste. $^{142}$ The efficient-use argument, however, has never trumped all restrictions on the use or sale of property. Land servitudes have long been accepted even though they may impede the transferability of restricted land; why should chattel servitudes be different?

Playing the balanced advocate, Chafee did suggest a couple of arguments for treating chattels differently. One argument was that the severity of the restraint might be greater for personal property than for land because the former is transferred more frequently than the latter, which stays in the same hands for relatively long periods of time ${ }^{143}$ It is an interesting argument, but quite backward. What counts is not product turnover but the durability of the restriction. A restriction on the use (or sale) of Blackacre can limit the use of a valuable resource for a very long time. Although deed covenants are subject to termination for changed conditions, and in some states by fixed statutory limitations, the duration of such covenants can be very long. Most restrictions on chattels will be self-liquidating in a short period of time simply because of the relatively shorter lifetime of the physical object. Indeed, in the one set of modern cases where chattel servitudes have been most controversial, the effective lifetime of the servitude is a matter of a few years because of the short functional lifetime of the product. Restrictions on the use or resale of Windows 95 became essentially obsolete soon after the release of Windows 98 , and similar restrictions on the latter will not long survive now that Windows 98 has been replaced with, successively, Windows 2000 and Windows XP. Granted, on the flip side the shorter lifetime of the product might imply a lower benefit-cost ratio than for restrictions on long-lived assets - the seller's benefits are lower and the information costs to the buyer are higher in relation to the value of the product. I concede the possibility, but it doesn't change the point made earlier about information costs and standardization: so long as these costs are transparent the market can regulate the benefit-cost calculus in the same way it does with other product variables. Any action that increases informa-

\footnotetext{
moral sense of debtors.

141 See text accompanying note 113.

142 See, for example, A. James Casner, ed, 6 American Law of Property $\$ 26.3$ at 412-14 (Little, Brown 1952) (discussing several "grave social and economic consequences" that would result from restraints on alienation). For a critique of the efficiency and related justifications, see Robinson, 91 Colum L Rev at 568-70 (cited in note 127).

143 Chafee, 41 Harv L Rev at 985 (cited in note 5).
} 
tion costs to the buyer is equivalent to raising the price of the product, and a rational seller will take that into account both in designing and marketing the product.

More important than the point about duration is the actual effect. A personal property restriction rarely removes a unique product from commerce. If the owner of Blackacre imposes very restrictive conditions on the use of the land, a unique resource may be effectively removed from seeking its highest valued use. Nothing like that occurs in the case of chattels, at least those chattels that are the objects of servitude-like restrictions. It is indeed quite ironic that resale price restrictions were declared invalid as restraints on alienability as well as restraints of trade. Whatever the validity of the second characterization - which is now a contested issue in antitrust - the first characterization is just a confusion. The last thing in the world a manufacturer wants to achieve by resale price restriction is to restrain alienability of the price-restricted good. When Bobbs Merrill affixed a notice on its books that they were not to be sold for less than a dollar, it was hardly trying to take the books out of commerce. Commerce cum alienation was the entire purpose of the transaction. This is not to deny that a restriction could have an adverse effect on the market; such is the conventional assumption underlying the antitrust ban on resale price fixing. However, antitrust policy should not be confused with alienability-even though the two might have been mistakenly linked originally. ${ }^{14}$ Suppose instead of fixing the resale price at which Macy's (among others) could sell its books, Bobbs Merrill had chosen instead to market its books only through selected book stores, excluding department stores or any other low-price retailer (grocery stores, for instance). The purpose of such selective distribution might be to ensure that the book is promoted in a certain manner or to target certain customers-a purpose many think is also served by resale price restrictions. ${ }^{14}$ Whatever the purpose, the effect is to restrict the distribution of the product and probably to restrict it far more than resale price fixing. Yet no one worth listening to would argue that such marketing restrictions should be held up to judgment under the common law policy against restraints on alienability."

If the case for forbidding alienability restraints gets little traction from arguments about the needs of commerce, it gets even less traction from arguments about buyer expectations. Granted, conventional understandings of property ownership include the right to use and transfer, so there is a natural presumption that a transfer of ownership

144 See text accompanying notes 65-70.

145 For a brief discussion, see Part III.B.2.

146 As it happens, such restrictions are also generally valid under antitrust law. See note 71 and accompanying text. 
would transfer these rights. It is only a presumption, though. Putting aside exogenous public policy objections to the restrictions, there is no basis for invalidating them on the grounds that they run counter to our usual understandings about what property ownership entails. Yet that is very close to the claim made by courts and commentators who insist that an end user license must be deemed to be a sale because it bears most of the characteristics of a sale and consumers understand it to be a sale. ${ }^{147}$ This is very peculiar. One might say the same about a transfer of a fee simple in Blackacre subject to deed covenants restricting the use of the land, but it would be frivolous to argue that a buyer's understandings about the normal incidents of a fee simple property interest trump the explicit deed restrictions.

Do buyers have different understandings about personal property? As we have already seen, personal property servitudes are unusual even if they are not unknown. Using conventional goods as a baseline, the emergence of license-based servitudes for digital goods is exceptional. One critic of software licensing has compared it to licensing books, a comparison intended to make the former seem eccentric and also overreaching on the part of the vendor. ${ }^{148}$ But why must transactions involving digital works follow the grooves created by other personal property transactions? At bottom the argument that licenses must be deemed to be a sale because that is the traditional mode for transferring rights in property simply reprises the formalism of the numerus clausus principle examined earlier. Critics may despise the practice of licensing, but it has persisted as a standard market practice for more than three decades. The persistence of a practice for such a long period suggests that there cannot be much divergence between consumer expectations and market norms.

I do not want to let the matter rest on the distinctiveness of digital property, however, for my argument is more general. Licensing

147 See, for example, SoftMan Products Co v Adobe Systems, Inc, 171 F Supp 2d 1075, 1085-

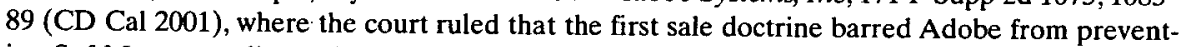
ing SoftMan, an online software distributor, from reselling Adobe software. SoftMan obtained "collections" of Adobe programs from authorized Adobe distributors; it unbundled the collection and resold the individual programs in violation of Adobe's distributor licenses and its end user licenses. Since SoftMan was not a licensed distributor it was not bound by that license and since it did not load the programs onto its computers it never was required to signify its consent to the shrinkwrap license. Adobe claimed, nevertheless, that SoftMan infringed its distribution rights, because the first sale doctrine did not apply to a product that was only licensed and not sold. The court rejected this claim on the grounds that Adobe's transactions had all the earmarks of a sale rather than a license: the purchaser commonly obtains a single copy of the product, makes a single payment, and the license runs for an indefinite term. Such factors "establish the expectations and intent of the parties." Id at 1086, quoting Raymond Nimmer, The Law of Computer Technology § 1.18[1] at 1-103 (Warren, Gorham \& Lamont 1992).

148 See Jessica Litman, The Tales that Article 2B Tells, 13 Berkeley Tech L J 931, 938-39 (1998) (asserting that a book license would be unenforceable based on the first sale doctrine). 
books seems strange because traditionally it has not made commercial sense for publishers to license rather than sell books. Publishers ordinarily have had no interest in limiting the end user's use of the book and no other apparent reason for preferring licensing to sale, so the practice never became established. ${ }^{149}$ But we should not think that there is some natural law of commerce forbidding this type of transaction. Audio books have been conventionally marketed for decades by means of rentals rather than sale, and no one finds this peculiar, let alone unlawful. ${ }^{150}$

\section{Fragmented property and the anticommons problem.}

Michael Heller's recent work on the "anticommons" has focused scholarly attention on the problem of property fragmentation. ${ }^{1.1}$ As with numerus clauses, the underlying issue transcends the small corner of property law with which I am concerned, but it has some relevance here that warrants a comment in passing. Just as numerus clausus addresses the question of the optimal standardization of the forms of property rights, one could say that the anticommons issue addresses the optimal size of property or property rights packages. ${ }^{1.2}$ The problem is most easily illustrated by land that is spatially divided into parcels too small to be economically valuable, thereby compelling needless transaction costs to aggregate the parcels into a viable unit. Or it is temporally divided into different estates that scatter ownership among different persons, again necessitating costly aggregation. Or the various sticks in the proverbial bundle of rights that conventionally comprise property rights may be disaggregated and distributed to

149 Bobbs Merrill is not to the contrary, despite Litman's suggestion. Id at 939. The publisher there was not trying to license books to the end user but was trying to set the price at which intermediate distributors could sell the book to end users. See notes 65-69 and accompanying text.

150 Under 17 USC $\$ 109$ (d), the owner's first sale rights do not extend to any person "who has acquired possession of the copy or phonorecord from the copyright owner, by rental, lease, loan, or otherwise, without acquiring ownership of it." Although book publishers have shown no interest in this kind of non-sale distribution, there is, of course, a retail rental market for recorded books, and at least one online retailer offers print copies of paperback books on a rental basis. Booksfree.com allows subscribers to "borrow" paperback books for an unlimited time, for a fixed monthly subscription fee, which includes the return mailing cost. See http://www.booksfree.com (visited July 23, 2004).

151 See Michael A. Heller, The Tragedy of the Anticommons: Property in the Transition from Marx to Markets, 111 Harv L Rev 621 (1998); Michael A. Heller, The Boundaries of Private Property, 108 Yale L J 1163 (1999).

152 Heller finds a relationship between numerus clausus and the anticommons problem insofar as the former limited intertemporal fragmentation via the fee tail. Heller, 108 Yale $\mathrm{L} \mathrm{J}$ at 1176-77 (cited in note 151). This is dubious. The abolition of the fee tail might be an (exceptional) illustration of numerus clausus inasmuch as it literally "closed" a form of property (albeit one that had ancient roots), but it is a stretch to attribute that closure to a concern about fragmentation of property when the common law left in place countless other ways to divide or fragment estates. 
different persons, yet again generating transaction costs in creating an economically useful unit of rights. It is not difficult to find real-world examples of each of these kinds of fragmentations in the case of land. Every first-year property student encounters the vexing problems that arise from proliferation of estates - at least if they are exposed to the infamous Rule against Perpetuities. ${ }^{153}$ And the same student may also encounter the spatial division problem if her instruction on takings law includes Hodel $v$ Irving, ${ }^{1,4}$ where the government sought (unsuccessfully) to control the fractionalization of Native American tribal lands.

It is less easy to find examples of the anticommons problem at work in personal property, though Heller and Rebecca Eisenberg have argued that one may exist in the patent field where the issuance of narrowly defined patents on genes could overly fragment property rights. ${ }^{155}$ By that same token, contractual restrictions on the use or sale of personal property (including intellectual property) arguably could have similar effects to the extent they strip away some of the important rights that normally go with the good in question.

The concern cannot be dismissed out of hand, but there is no evidence that it is a substantial problem. The Heller-Eisenberg concern is legitimate, but also irrelevant here. The creation of property servitudes is not a matter of creating property rights ex nihilo (as in the patenting of small gene fragments). Rather it is a matter of an owner deciding whether or not to carve out certain rights in his transactions with others. Again, it is important to focus on the commercial context, which is the only context in which personal property servitudes arise. The owner of a good seeks to maximize his profit from the sale (or rental) of that good. He has no reason to fetter the use of the good in ways that will destroy its commercial value; given a reasonably wellfunctioning market, any such move will be short lived. Of course, some kinds of constraints will prove to be market losers, but that is not a reason to alter the basic framework of property rights. If the market provides the mechanism for ensuring that the costs, as well as the benefits, of these kinds of restrictions are internalized to the owner, that should be sufficient. If the market does not provide that mechanism, then the appropriate focus is on the market, not on the property rights system.

153 Heller notes that the Rule against Perpetuities can be understood as an attempt to control the problem - a failed attempt given its limited application to the problem. Id at 1179-82.

154481 US 704 (1987) (declaring a statute that prohibited Native Americans from devising small, undivided interests in tribal land to be an unconstitutional taking of property).

155 Michael A. Heller and Rebecca S. Eisenberg, Can Patents Deter Innovation? The Anticommons in Biomedical Research, 280 Science 698 (1998). 


\section{B. Restraint of Trade}

1. Monopoly and misuse.

At bottom, many of the objections to restrictions on personal property are grounded more in concerns about monopoly than concerns about the free flow of property in commerce. Unfortunately, the concerns that have been expressed about monopoly have been quite as confused as those expressed about transferability. Part of the confusion arises from the conflation of intellectual property rights with monopoly, a conflation that Edmund Kitch has aptly described as an "elementary and persistent error." has a kind of "monopoly" in the sense that she can exercise full control over the owned object; this is implicit in the holdout power that is the core of all exclusive property rights. However, such an ownership power may or may not have economic significance. It is trivial that property rights in general are a necessary condition of market power since no one could monopolize or control a market if she did not have exclusive rights to its products or its productive assets.

These conditions apply to common law property as well as intellectual property. It is not common to associate common law property rights with monopoly because a right to exclude others from one's property is rarely sufficient to create market power. But it sometimes is. Where the property is an "essential facility," access to which is required to support competition in a market for which the facility is an indispensable input, the right to exclude entails, by definition, the power to monopolize. ${ }^{157}$ However, no property right-common law, copyright, or patent-can be a source of market power unless it pro-

156 Edmund W. Kitch, Elementary and Persistent Errors in the Economic Analysis of Intellectual Property, 53 Vand L Rev 1727, 1729-38 (2000) (arguing against the error of "analyz[ing] intellectual property rights on the assumption that they confer an economic monopoly on their owner"). Sometimes the reference to "monopoly" seems to be merely a casual shorthand for the possibility that a patent might produce monopoly. See, for example, Judge Richard Posner's opinion in Scheiber v Dolby Laboratories, Inc, 293 F3d 1014, 1018 (7th Cir 2002) (referring to the fact that a "patent confers a monopoly" as a reason for limiting its term); Eldred $v$ Ashcroft, 537 US 186, 243 (2003) (Breyer dissenting) (referring to the "'monopoly privileges' that the Copyright Clause confers"). However, in most instances, the "monopoly" label is used to suggest that an actual economic monopoly is conferred-as is most strikingly indicated in tying cases where the existence of an intellectual property right is presumed to confer the requisite market power for such arrangements to be deemed illegal. See, for example, United States v Loew's Inc, 371 US 38, 45 (1962) ("The requisite economic power is presumed when the tying product is patented or copyrighted.").

157 For recent discussions of the antitrust and regulatory aspects of essential facilities, see Robinson, 87 Cornell L Rev at 1204-30 (cited in note 39) (arguing that refusals to deal should be eliminated as a separate antitrust violation except in cases involving essential facilities); Abbott B. Lipsky, Jr. and J. Gregory Sidak, Essential Facilities, 51 Stan L Rev 1187, 1211-23 (1999) (discussing the relationship between the regulation of monopoly and the essential facilities doctrine). 
tects a product for which there is a market demand and for which there are limited substitutes.

It is regularly observed that most patents-the form of intellectual property most commonly associated with monopoly-are economically worthless, ${ }^{138}$ which necessarily precludes an economic monopoly. It may be semantically acceptable to speak of a patent monopoly for "a device for protecting the ears of animals, especially longhaired dogs, from becoming soiled by the animal's food while the animal is eating." 159 But if monopoly is understood as an economic concept, this would be a very eccentric usage since it is extremely unlikely that there is such a demand for this product as to permit the patent owner to earn economic rents from its sale. What is true of patents is even more self-evidently true of most copyrighted works, however much they may be prized by their authors. ${ }^{100}$ Granted, a strong patent or copyright can be a source of just such power, as it is for Microsoft's monopoly of operating systems. ${ }^{161}$ But the example is even more compelling proof of the absence of any necessary correlation between copyright and market power; after all, Microsoft's competitors in the operating systems market also have copyrights. ${ }^{162}$ Patents are more likely to be the source of monopoly power than copyrights because of the greater breadth of the exclusive rights they confer, but most patents still cover only selective features of a product that do not foreclose competitive opportunities for the end product.

A second source of confusion is the frequent association of use and sale restrictions on intellectual property with the doctrine of misuse, which in turn is conventionally associated with (though not coextensive with) antitrust. The subject of misuse is much too large and complex to examine here beyond making a few observations about its relationship to restrictions on the use of intellectual property. Misuse has long been recognized as an equitable defense to patent infringement or royalty claims, ${ }^{163}$ whence it has been recently imported by a

158 See, for example, Clarisa Long, Patent Signals, 69 U Chi L Rev 625, 626 (2002) (noting that "worthless patents abound"); Edmund W. Kitch, Property Rights in Inventions, Writings, and Marks, 13 Harv J L \& Pub Policy119, 122-23 (1990) ("[M]ost issued patents are worthless, or very nearly worthless. They have no market value, much less market power.").

159 See James D. Williams, Animal Ear Protectors, US Patent No 4,233,942 (Nov 18, 1980).

160 Since any original work of expression in a tangible medium automatically receives copyright protection upon its creation, one needs only to scan a random assortment of school administration memos, exam bluebooks - or, dare I admit, law review articles-to prove the proposition that there is no necessary correlation between copyright and monopoly power.

161 See United States v Microsofi Corp, 253 F3d 34, 54-58 (DC Cir 2001) (holding that Microsoft's Windows is a monopoly in the market for personal computer operating systems).

162 Including Linux, although Linux is licensed as open source. See note 215.

163 The seminal patent case on misuse is Morton Salt Co v G.S. Suppiger Co, 314 US 488 (1942) (rejecting an infringement suit because of the plaintiff's misuse of its own patent, regardless of whether the infringing defendant was harmed by the patent misuse). For an overview of 
number of lower courts into copyright law. ${ }^{1 / 4}$ The relationship between misuse and the first sale doctrine is confusing. In patent cases there has been a tendency to invoke misuse in every first sale case on the notion that it entails an attempt by the patent owner to claim powers beyond the scope of the patent grant.

This association between first sale and misuse probably derives from the single-reward idea that a patent owner is entitled only to a single reward that is "exhausted" by the first sale of the patented article. ${ }^{165}$ However, as a general explanation for the first sale doctrine, the one-reward idea is empty. As a matter of ordinary property law owners are not restricted in the type of consideration they may seek for the sale of their property. If the owner of Blackacre chooses to sell it subject to some set of use restrictions (for instance, no pink flamingos on the lawn) she may do so, subject to some set of public policy limits that the law imposes on servitudes generally. The matter is essentially no different for intellectual property. Even if one chooses to treat a patent owner as a monopolist there is no obvious policy rationale for restricting the form or amount of the "reward" she may obtain from the patent. Notwithstanding the commonplace assumption that the reward to the patent "monopolist" should be no greater than is necessary to fulfill the special purposes of the patent grant, the patent law does not prescribe a fixed schedule of allowable returns from the patent or the form in which they can be received. ${ }^{166}$ It is elementary that even a monopolist is limited in the amount of reward that it can obtain by market conditions, but the question here is whether the reward of the patent owner should be additionally restricted in how that reward is structured. In other words, if the patent owner wants to take

misuse in patent, copyright, and trademark law, see Intellectual Property Misuse (cited in note 61).

164 The leading case is Lasercomb America, Inc $v$ Reynolds, 911 F2d 970,976 (4th Cir 1990) ("[S]ince copyright and patent law serve parallel public interests, a 'misuse' defense should apply to infringement actions brought to vindicate either right."). The importation of misuse into copyright has been favorably received by most commentators, who have seen it as a means of curbing software license restrictions. See, for example, Brett Frischmann and Dan Moylan, The Evolving Common Law Doctrine of Copyright Misuse: A Unified Theory and Its Application to Software, 15 Berkeley Tech L J 865, 919-27 (2000) (arguing that copyright misuse "correct[s] an internal deficiency in the Copyright Act, [ ] coordinate[s] copyright law with patent and antitrust law, and [ ] safeguard[s] policies of copyright law"); Lemley, $87 \mathrm{Cal} \mathrm{L} \mathrm{Rev} \mathrm{at} \mathrm{151-58} \mathrm{(cited} \mathrm{in} \mathrm{note} \mathrm{101)}$ ("[C]opyright misuse doctrine readily disposes of the 'contracts are different' canard, because it so clearly operates ... to restrict the enforcement of anticompetitive licensing provisions.").

165 A similar exhaustion-of-reward idea for copyright is advanced by Paul Goldstein, 1 Copyright $\$$ 5.6.1.1(b) at 598 (Little, Brown 1989) (stating that a copyright owner is entitled to "no more than the opportunity to realize the full value of each copy or phonorecord upon its disposition").

166 Ward S. Bowman, Jr., Patent and Antitrust Law 54 (Chicago 1973), makes the same point in his thoughtful analysis of patent restrictions, but it is quite surprising how rarely this seemingly commonplace observation is found in discussions of the subject. 
some of its economic rent in the form of limitations on use instead of cash, why should that be deemed outside the patent grant? Although there are some exogenously set restrictions on the ability of the patent owner to leverage the patent right to secure market power in other fields, ${ }^{167}$ these are properly defined by antitrust principles and not by a generic first sale doctrine. The same is true for copyright misuse claims.

Characterizing a violation of the first sale doctrine as a misuse primarily serves a remedial purpose. Ordinarily it should be sufficient to enforce the first sale doctrine by simply withholding enforcement of any restrictions that violate it; however, characterizing such restrictions as a misuse of the property right has the additional effect of making the underlying property right unenforceable against any person until the misuse is "purged" by some affirmative action of the property owner. ${ }^{168}$ The additional force of this misuse defense-a kind of in rem defense-seems to imply an assumption that the property owner has not merely strayed over the boundary of his property right but has sought purposefully to leverage his property right to achieve an illegal purpose-notably a restraint of trade. Although the misuse doctrine is said to be an extension of the general equity doctrine of unclean hands, ${ }^{169}$ this may be a little misleading. Unlike the typical unclean hands case that deals with ad hoc equities between two parties, most misuse cases involve general practices that are deemed to be not merely "inequitable" vis-à-vis a particular licensee or user but harmful to the market generally because of the "monopoly power" that is (incorrectly) presumed to be inherent in the property right.

This economic harm is preeminently, even if not entirely, a concern of the antitrust laws. Although the Supreme Court long ago ruled that misuse was not confined to practices that violated antitrust law, ${ }^{170}$ lower court decisions since then have professed to be guided by antitrust policy. ${ }^{171}$ The distinction between being confined to antitrust law and being guided by it appears to mean that while misuse involves

167 See, for example, Morton Salt, 314 US at 491 ("[A] patent affords no immunity for a monopoly not within the grant.").

168 Id at 493 (stating that a court may decline to enforce the misused patent "until it is made to appear that the improper practice has been abandoned and that the consequences of the misuse of the patent have been dissipated").

169 See, for example, United States Gypsum Co v National Gypsum Co, 352 US 457, 465 (1957) (noting that the misuse doctrine is "an extension of the equitable doctrine of "unclean hands' to the patent field").

170 Zenith Radio Corp v Hazeltine Research, Inc, 395 US 100, 140 (1969).

171 See Gordon and Hoerner, Overview and Historical Development at 22-28 (cited in note 61) (listing recent cases and legislation that have limited misuse to antitrust principles). Judge Posner's survey of the cases in 1982 found no cases in which misuse standards yielded results different from those that would be reached under the antitrust laws. USM Corp v SPS Technologies, Inc, 694 F2d 505, 511-12 (7th Cir 1982). 
practices that are within the general domain of antitrust, it is not required to prove all of the elements necessary to establish antitrust liability, such as market power. This is an intelligible distinction, but whether it has any practical bite is uncertain. For instance, the Federal Circuit (which has exclusive jurisdiction over patent infringement actions, hence patent misuse) applies a standard for misuse that very largely tracks the standards of antitrust liability. In Virginia Panel Corp v MAC Panel Co, ${ }^{12}$ the court summarized its approach as follows:

When a practice alleged to constitute patent misuse is neither per $s e$ patent misuse nor specifically excluded from a misuse analysis by [35 USC] $\S 271$ (d), a court must determine if that practice is reasonably within the patent grant, i.e., that it relates to subject matter within the scope of the patent claims. If so, the practice does not have the effect of broadening the scope of the patent claims and thus cannot constitute patent misuse. If, on the other hand, the practice has the effect of extending the patentee's statutory rights and does so with an anti-competitive effect, that practice must then be analyzed in accordance with the "rule of reason." Under the rule of reason, "the finder of fact must decide whether the questioned practice imposes an unreasonable restraint on competition, taking into account a variety of factors, including specific information about the relevant business, its condition before and after the restraint was imposed, and the restraint's history, nature, and effect."173

Under this formulation the only practices that might constitute misuse that would not run afoul of antitrust law would be a very narrow class of cases that the Supreme Court has found to be per se misuse. Interestingly, the court gave only two examples - tying arrangements and attempts by a patentee to extend the term of its patent by requiring post-expiration royalties. ${ }^{174}$ As it happens, though, tying is also a per se antitrust offense where the seller has market power with respect to the tying good, and a 1988 amendment to the Patent Act requires that tying is not a misuse except where the patentee is shown to have market power in the market for either the patent or the patented good. ${ }^{175}$ In these cases misuse is not doing any work that is not

172133 F3d 860 (Fed Cir 1997).

173 Id at 869 (internal citations omitted), quoting Mallinckrodt, $976 \mathrm{~F} 2 \mathrm{~d}$ at 708, and State Oil Cov Khan, 522 US 3, 10 (1997).

174 Virginia Panel, 133 F3d at 869.

175 See 35 USC $\$ 271(d)(5)(2000)$. Since antitrust law presumes that the patent itself is sufficient to establish market power, see, for example, Loew's, 371 US at 45, this restriction apparently makes the misuse defense less expansive than the corresponding antitrust offense. 
done more simply by antitrust law. The second exception, postexpiration royalties, rests on what can only be described as a formulaic decision $^{176}$ that makes no sense in terms of patent or antitrust policy. ${ }^{17}$ Outside the Federal Circuit most of the courts that have approved application of the misuse doctrine to copyright appear to have a more expansive view of its application, though it is too early in the evolution of copyright misuse to draw reliable conclusions. ${ }^{178}$

Even if market power is not a prerequisite to finding misuse, the recognition of antitrust policy as a general benchmark for evaluating practices by property owners implies that practices must be shown to be harmful to competition, not simply to competitors (such as infringers). ${ }^{179}$ With that as a general premise, I want to examine three types of restraints that might be thought to raise restraint of trade cum misuse issues. Two involve restraints by upstream sellers on downstream distributors-prescribing resale prices or nonprice restrictions on how, or to whom, the product is sold. Because they are interrelated, I shall treat them together, though antitrust law treats them as different. The third involves restraints on end users-limiting resale or other uses of the product, such as reverse engineering. Here the restrictions may or may not be part of a marketing plan by the seller. Restrictions on re-

176 See Brulotte $v$ Thys Co, 379 US 29 (1964). The formulaic character of the decision is the subject of Justice Harlan's dissent, id at 34-39. The Court did not actually hold that fixing royalties that extended beyond the patent life was a misuse. Although it strongly suggested such a holding by labeling the practice "unlawful per se," id at 32 , it ruled only that the licensing agreement was unenforceable. Lower courts have divided on the question of whether the use of postexpiration royalty provisions is a misuse that renders the entire patent unenforceable. See Nicholas Coch and Heidi Chen, Specific Practices That Have Been Challenged as Misuse, in Intellectual Property Misuse 37, 50-52 (cited in note 61) (noting the circuit split).

177 See, for example, Scheiber, 293 F3d at 1018 (criticizing the decision in Brulotte, but noting that it has not been overruled). See also Edward F. Sherry and David J. Teece, The Misuse Doctrine: An Economic Reassessment, in Intellectual Property Misuse 125, 137-38 (arguing that post-expiration royalties can involve mutually beneficial deals).

178 Frischmann and Moylan, 15 Berkeley Tech L J at 888-97 (cited in note 164), summarize the positions of the various circuits that have pronounced on the subject. At least two circuits, the Seventh and Eighth, have clearly aligned themselves with the Federal Circuit's approach in patent cases - that courts considering misuse should apply antitrust law, using a rule of reason analysis. See Saturday Evening Post Co v Rumbleseat Press, Inc, 816 F2d 1191, 1200 (7th Cir 1987) (holding that a no-contest clause in a copyright licensing agreement is invalid only if it violates antitrust law); United Telephone Co of Missouri v Johnson Publishing Co, Inc, 855 F2d 604, 611-12 (8th $\mathrm{Cir} 1988$ ) (extending the misuse doctrine to copyrights and applying a rule of reason analysis based in antitrust principles). The Fourth, Fifth, and Ninth Circuits have indicated that misuse is not limited to antitrust policy. See Lasercomb, 911 F2d at 978 ("[A] misuse need not be a violation of antitrust law in order to comprise an equitable [infringement] defense."); DSC Communications Corp v DGI Technologies, Inc, 81 F3d 597, 601 (5th Cir 1996) (concurring with Lasercomb's characterization of the copyright misuse defense); Practice Management Information Corp v American Medical Association, 121 F3d 516, 521 (9th Cir 1997) ("[A] defendant in a copyright infringement suit need not prove an antitrust violation to prevail on a copyright misuse defense.").

179 See, for example, Brunswick Corp v Pueblo Bowl-O-Mat, Inc, 429 US 477, 488 (1977) (noting that antitrust laws protect competition, not competitors). 
sale or multiple uses by end users can serve functions similar to restrictions on intermediate distributors, but restrictions on reverse engineering serve a distinctive purpose of protecting trade secrets.

\section{Controlling distribution.}

Resale price fixing was first condemned as both a restraint on alienability under property law and a restraint of trade under antitrust law. ${ }^{180}$ However, as noted, the first characterization involves a rather odd conception of the common law policy since resale price restrictions are hardly designed to remove the goods from commerce (as the word "resale" itself demonstrates). Rather, the inalienability characterization is best understood to refer to the restraint on downstream sellers' freedom to market their goods, which segues into the second policy objection against trade restraints. That segue, however, is neither simple nor obvious. To the extent that seller freedom is an important element of trade policy, one must account for why the downstream seller's freedom to sell on its own terms is preferred over the upstream seller's freedom to sell on such terms as it prefers. The Supreme Court acknowledged the point in United States $v$ Colgate \& $\mathrm{Co}{ }^{181}$ when it held that resale price restrictions were lawful provided that they did not involve an explicit agreement. ${ }^{182}$

The distinction between resale price setting by unilateral action and resale price setting by agreement has proved to be troublesome, and not only because of the evidentiary difficulties involved in determining whether a given restraint is a product of one or the other. ${ }^{183}$ The distinction also raises a more basic question about why resale price fixing is bad. Since Dr. Miles Medical Co v John D. Park \& Sons $\mathrm{Co},{ }^{184}$ agreements to fix resale prices have been equated with price fixing among competitors, the quintessential conspiracy in restraint of

\footnotetext{
180 See note 70.

181250 US 300 (1919).

182 Id at 307-08:
}

[The Sherman Act] does not restrict the long recognized right of trader or manufacturer engaged in an entirely private business, freely to exercise his own independent discretion as to parties with whom he will deal. And, of course, he may announce in advance the circumstances under which he will refuse to sell.

183 See Business Electronics Corp v Sharp Electronics Corp, 485 US 717, 726-27 (1988) (holding that even a showing of agreement between a supplier and a dealer to terminate another dealer is insufficient unless it is shown that there was an agreement about resale prices, as opposed to price-related services); Monsanto Co v Spray-Rite Service Corp, 465 US 752, 762-64 (1984) (stating that agreement may not be inferred simply from the fact that an upstream supplier terminated a downstream dealer following complaints by other retailers that the terminated dealer was discounting prices).

184220 US 373 (1911). 
trade. ${ }^{1.5}$ However, the equation of vertical and horizontal price fixing is problematic. ${ }^{186}$ Because upstream and downstream firms do not compete with one another it is not at once obvious why an agreement $b e$ tween them to fix resale prices would be treated the same as an agreement between competitive firms. The Court in Dr. Miles did not offer an explanation, presumably because it equated the effects of horizontal and vertical price agreements: suppression of price competition among downstream sellers. As antitrust theory matured, the nature of the relationship between the vertical arrangement and the horizontal effect was articulated in theories suggesting that vertical price fixing can be a means of organizing or enforcing cartels either among dealers or among manufacturers. ${ }^{187}$

Whatever the theory, until comparatively recent times antitrust lawyers and economists almost unanimously agreed that resale price fixing was an inexcusable restraint of trade. ${ }^{188}$ Today, that consensus no longer exists. Agreements to fix minimum resale prices are still per se illegal, though fixing maximum prices is now evaluated under a rule of reason. ${ }^{189}$ Even with respect to minimum price fixing, opinion has shifted significantly. A significant body of scholarship now argues that

185 See, for example, United States v Socony-Vacuum Oil Co, Inc, 310 US 150, 224-26 n 59 (1940) (providing the leading formulation of the rule of per se illegality for horizontal price fixing).

186 See Robinson, 80 Va L Rev at 601-19 (cited in note 71) (arguing that while the per se illegality of horizontal price restraints can be justified, the condemnation of vertical price restraints is unsupported by economic theory or evidence).

187 The two cartel possibilities commonly are bracketed as if they enjoyed equal authority. However, the retail cartel explanation is the older theory and seems most congruent with the fact that initiatives and legislation for fair trade were promoted mainly by retailers (most notably druggists), not manufacturers. See Federal Trade Commission, Resale Price Maintenance: Summary and Conclusion 31-35 (1945); B.S. Yamey, The Origins of Resale Price Maintenance: $A$ Study of Three Branches of Retail Trade, 62 Econ J 522 (1952) (tracing the evolution of retail price maintenance in groceries, drug and patent medicine, and tobacco as a reaction among retailers to price-cutters in which the retailers banded together to force manufacturers to engage in retail price maintenance). The earliest complete articulation of a manufacturer cartel theory appears to be Lester G. Telser, Why Should Manufacturers Want Fair Trade?, 3 J L \& Econ 86 (1960), though it is briefly suggested earlier in Ward S. Bowman, Jr., The Prerequisites and Effects of Resale Price Maintenance, 22 U Chi L Rev 825, 838-39 (1955).

188 A measure of such agreement is the fact that in 1952 even such conservative economists as Aaron Director and Milton Friedman joined liberal economists like John Kenneth Galbraith and James Tobin (among many other academics) in urging repeal of state fair trade laws that authorized resale price fixing agreements. See Thomas R. Overstreet, Jr., Resale Price Maintenance: Economic Theories and Empirical Evidence 8 n 3 (FTC 1983). See also The Attorney General's National Committee to Study the Antitrust Laws 154-55 (GPO 1955) (recommending repeal of the Miller-Tydings amendment and the McGuire amendment to the Fair Trade Commission Act, which together authorized state fair trade laws). In 1975 Congress finally repealed the federal laws permitting states to authorize fair trade agreements. See Consumer Goods Pricing Act of 1975, Pub L No 94-145, 89 Stat 801.

189 State Oil, 522 US at 18,22 , held that maximum resale prices are no longer subject to per se condemnation, though they remain subject to the rule of reason. 
the rule of per se illegality is not justified. ${ }^{190}$ Indeed, the Justice Department itself tried some years ago to get the rule reversed. ${ }^{191}$ The shift in opinion reflects growing recognition that, although resale price fixing limits intrabrand competition, it also promotes interbrand competition. Beginning with Lester Telser's pioneering analysis in 1960, which argued that fixing resale prices was a means of supporting point-of-sale services, ${ }^{12}$ a number of related theories have been formulated about the use of vertical restraints as an efficient means of marketing branded goods. ${ }^{193}$ Although the Supreme Court has yet to accept any of these benign accounts as justification for fixing minimum prices, it has done so for nonprice restraints that were once regarded as indistinguishable from price restraints. ${ }^{194}$ Given its acceptance of nonprice constraints as well as the recent trend away from per se rules in antitrust generally, ${ }^{105}$ it would not be rash to predict that the Court will abandon its per se rule for minimum resale price restraints.

190 See, for example, William A. Baxter, The Viability of Vertical Restraints Doctrine, 75 Cal L Rev 933 (1987) (arguing that vertical restraints are actually used as part of vertical integration and that they should not be per se illegal, although conceding that politics will likely keep them that way); George A. Hay, Vertical Restraints after Monsanto, 70 Cornell L Rev 418, 433-35 (1985) (arguing that "the economic effects of price and nonprice restrictions are often indistinguishable" and thus the "price-nonprice distinction seems to be an exercise in semantics"); Richard A. Posner, The Next Step in the Antitrust Treatment of Restricted Distribution: Per Se Legality, $48 \mathrm{U}$ Chi L Rev 6, 8-14 (1981) (arguing that all purely vertical restraints, including resale price maintenance, should be declared legal per se).

191 See Monsanto, 465 US at 761-62 n 7 (noting the Solicitor General's argument that "the economic effect of resale price maintenance is little different from agreements on nonprice restrictions," though the Court declined to reach the issue).

192 Telser, $3 \mathrm{~J} \mathrm{~L} \mathrm{\&} \mathrm{Econ} \mathrm{at} \mathrm{89-96} \mathrm{(cited} \mathrm{in} \mathrm{note} \mathrm{187).} \mathrm{It} \mathrm{should} \mathrm{be} \mathrm{emphasized} \mathrm{that} \mathrm{Telser} \mathrm{did}$ not present the distribution services theory as an exclusive explanation. He not only acknowledged the retail cartel explanation, id at $86 \mathrm{n} 1$, but developed at length the manufacturer's cartel explanation. Id at 96-104.

193 See, for example, Benjamin Klein and Kevin M. Murphy, Vertical Restraints as Contract Enforcement Mechanisms, 31 J L \& Econ 265, 294-96 (1988) (arguing that retail profit margins induce the provision of retail services by creating rent streams that would be lost if the supply terminated); Patrick Rey and Jean Tirole, The Logic of Vertical Restraints, 76 Am Econ Rev 921 , 921-22 (1986) (arguing that retail margins protect manufacturers against demand uncertainty); Victor P. Goldberg, The Free Rider Problem, Imperfect Pricing, and the Economics of Retailing Services, $79 \mathrm{Nw}$ U L Rev 736 (1984) (stating that retail profit margins pay for premium shelf space, product endorsement, and dealer loyalty).

194 See Continental TV, Inc v GTE Sylvania, Inc, 433 US 36, 58-59 (1977) (holding that location-restriction clauses in franchise agreements that fixed exclusive territories for retailers were not per se illegal, but should be evaluated using rule of reason analysis). See also Business Electronics Corp, 485 US at 723-28 (holding that, to come within the per se rule for resale price maintenance, there must be clear proof of an agreement to fix prices; where evidence permits an equally plausible inference that the dealer termination was based on nonprice conditions, the termination cannot be judged by the per se rule).

195 The latest indication of this trend is California Dental Association v FTC, 526 US 756 (1999), where the Court demanded a full rule of reason analysis for professional restrictions on price advertising - practices the court of appeals (correctly in my view) deemed to be a "fairly 'naked' restraint on price competition itself." Id at 763, citing California Dental Association v FTC, 128 F3d 720, 727 (9th Cir 1997). 
However, the future antitrust treatment of resale price fixing is only tangentially relevant to the present discussion. Whatever antitrust policy says about such price restrictions, that policy should be recognized as an exogenous constraint on property rights, not an endogenous definition of property rights. The distinction between exogenous and endogenous only seems like academic mystification; in fact it has important practical consequences. Treating the restraint as an exogenous element of public policy rather than an endogenous feature of the property right itself invites more focused attention to the nature of the policy being invoked. We tend to think of property rights, like all rights, as standing apart from the ever-changing circumstances that shape public policies in the political realm. This is admittedly less true of intellectual property where the statutes that define the property rights bear a quite visible imprint of interest group politics. Yet even here the common vocabulary of rights-however defined or limited-has the effect over time of obscuring the political interests - and policies - that produced those rights in the first instance. One consequence of this effect is that the definition of property rights does not always change to reflect changes in, or new understandings of, the underlying policy. To the extent that property rights are limited by contingent public policies, the limitations should not be allowed to survive beyond those policies. The concern is that when those policies are incorporated into the structure of property rights, they will prove to be more difficult to change. Again, this may be less of a problem with intellectual property rights simply because they are the product of statutes and thus expected to be more susceptible to political change. However, even here there is a legitimate concern about locking politically contingent policy into the structure of property rights that are (usually) expected to be more enduring.

As an example of the problem, consider what happened in Bobbs Merrill. ${ }^{196}$ Resale price restrictions were determined to be socially harmful; that harm was then broadened into a rule about the property right in question - namely that the copyright owner's right to distribute was extinguished by the first sale. The second move was unnecessary. The first was sufficient to achieve the result and would have left open for examination in other contexts whether other sale or use restrictions should be permitted based on their particular effects. It would also make it easier to adapt the rule to changes in social policy. Of course, property rights must be shaped by social policy. However, by treating the social policy as an intrinsic element of the property right, one runs the risk of an unnecessary lock-in effect. 
The importance of distinguishing between an exogenous policy constraint and an endogenous, definitional limitation on property is even more evident where the policy is itself rather amorphous, as is the case with nonprice restrictions. Antitrust law does not say that such restrictions are always lawful, but it does say they are not per se unlawful - they are judged by a rule of reason. ${ }^{1.7}$ Some antitrust scholars view the distinction between price and nonprice restraints as rather arbitrary, if not simply mistaken, since both types of restriction have similar downstream effects. ${ }^{198}$ Whether the antitrust distinction is mistaken is neither here nor there; what is important is that the antitrust policy not be distorted by translating it into a property rule. Unfortunately, as we just noted, when property rules become defined according to a set of shifting social policies they become susceptible to lock-in effects that persist after the policy has changed. At one time antitrust law treated vertical agreements restricting downstream distributors from selling outside prescribed distribution channels the same as horizontal territorial restrictions-both were deemed per se illegal. ${ }^{199}$ The Court abandoned the per se rule for vertical nonprice restrictions on the grounds that restricting channels of distribution in this way may be economically efficient and also beneficial to consumers. $^{200}$ To the extent, however, that all restraints on resale are considered to be beyond the seller's property right in the goods being restricted-as in the case of intellectual property under the first sale rule-a practice regarded as efficient and beneficial becomes unlawful. Why? It is no answer to say that imposing such restrictions is an attempt to redefine the balance between the owner's exclusive property rights on the one hand and the public's rights on the other. ${ }^{201}$ Taking the first sale rule as a given, that is true, but it does not explain why the rule exists in the first place-why this particular limitation is appropriate.

197 Continental TV, 433 US at 58-59 ("[D]eparture from the rule-of-reason standard [for vertical restraints on trade] must be based upon demonstrable economic effect rather than ... upon formalistic line drawing.").

198 See Hay, 70 Cornell L Rev at 433-35 (cited in note 190) (noting that a "manufacturer may, subject to the rule of reason, implement nonprice restraints for the purpose, and with the effect, of eliminating intrabrand competition," but attempting to "accomplish the same result" with price restrictions is per se illegal).

199 See United States v Arnold, Schwinn \& Co, 388 US 365, 377-78 (1967) (striking down vertical restrictions requiring distributors to confine resales of goods to "franchised" retailers).

200 See Continental TV, 433 US at 54-55 ("Vertical restrictions promote interbrand competition by allowing the manufacturer to achieve certain efficiencies in the distribution of his products.").

201 See, for example, David A. Rice, Public Goods, Private Contract and Public Policy: Federal Preemption of Software License Prohibitions against Reverse Engineering, $53 \mathrm{U}$ Pitt L Rev $543,545-46$ (1992) ("The design of both patent and copyright law strikes a balance between creating incentives to innovate or create and assuring that others have access to the resulting fruits of intellectual endeavor."). 
It is not surprising that at least some courts have been disposed to allow the rule to be circumvented by the simple expedient of licensing rather than selling. The puzzle is why they should be forced into such a mode in order to accomplish a generally benign result. A recent decision involving the distribution of Adobe Systems' popular Acrobat program illustrates. ${ }^{202}$ Acrobat is sold in commercial and educational versions. The two versions of the program have only minimal differences, but authorized educational users are given a substantial discount from the commercial price. Presumably to maintain the price difference, Adobe distributes the educational version only through authorized educational resellers, pursuant to a reseller agreement that requires the reseller to sell the program only to educational end users at the reseller's outlet or through its own sales force. An unauthorized reseller obtained the software (presumably from an authorized reseller-we are not told), removed it from its original shrinkwrap package and removed all identification designating it as the educational version, and then resold it to non-educational commercial users. Adobe sued the unauthorized distributor for, among other things, copyright infringement on the grounds that its resale violated Adobe's exclusive distribution right. Defendant invoked the first sale doctrine. The court held that the doctrine did not apply because Adobe had not transferred title; it had merely licensed the software (both to the retailer and to the end user).

As noted earlier, many commentators have criticized the use of the "license" tag to avoid the first sale rule, both in copyright and patent cases. ${ }^{204}$ The critics have a point; what is the use of having a first sale rule if its only effect is simply to force the owner to re-label the transaction? However, the artificiality of this evasion is fully matched by the arbitrariness of the underlying rule. Instead of merely chanting "first sale," it ought to be possible to examine with particularity the good and bad effects of the restrictions that the "seller" seeks to impose.

In the Adobe case, the purpose of the restriction was price discrimination. Price discrimination is an accepted feature of modern markets, as anyone knows if she has bought an airline ticket, used a special discount card at the grocery store, or negotiated a price for a

202 Adobe Systems Inc v One Stop Micro, Inc, 84 F Supp 2d 1086 (ND Cal 2000).

203 Id at 1092 ("[B]ased upon the undisputed evidence ... regarding the intent of the parties in entering into the agreement, trade usage, the unique nature of distributing software, as well as the express restrictive language of the contract, [the reseller agreement] is a licensing agreement."). See also ProCD, 86 F3d at 1455 (holding that shrinkwrap licenses may be enforced against the party to the contract). But see SoftMan, 171 F Supp 2d at 1086 (stating that the first sale doctrine applied because the purported license transaction was, in reality, a sale).

204 See text accompanying notes $84-89$. 
new car. ${ }^{205}$ The economic welfare effects of price discrimination are complicated in ways we need not explore here. ${ }^{206}$ Suffice it to say that, as a matter of general economic theory, systematic price discrimination can be efficient or inefficient depending on whether it increases total output or merely reallocates output between buyers with different price elasticities. ${ }^{207}$ The same ambiguity holds on a more mundane level of competition policy. The Robinson-Patman Act condemns systematic price discrimination where it ostensibly harms competition either between the seller and its rivals or between downstream competitive buyers ${ }^{208}$ but it is generally acknowledged that the Act has been used to suppress more than support competition. ${ }^{209}$ What all this suggests is that without a detailed investigation of particular markets it is impossible to say whether price discrimination enhances or diminishes total economic surplus (the total of consumer and producer surplus).

205 In each of these cases, the buyers sort themselves into different groups by their search behavior in contrast to the Adobe case where the seller has identified two specific groups with different demands. A common parallel to the Adobe case would be price discounts offered to senior citizens.

206 For general discussions of these effects, see Dennis W. Carlton and Jeffrey M. Perloff, Modern Industrial Organization 289-91 (Addison-Wesley 3d ed 2000); F.M. Scherer and David Ross, Industrial Market Structure and Economic Performance 494-508 (Houghton Mifflin 3d ed 1990).

207 See generally Jerry A. Hausman and Jeffrey K. MacKie-Mason, Price Discrimination and Patent Policy, 19 RAND J Econ 253, 253-55 (1988) (arguing that price discrimination may allow the opening of new markets and/or the achievement of economies of scale, which will increase social welfare and even cause Pareto improvements); Richard Schmalensee, Output and Welfare Implications of Monopolistic Third-Degree Price Discrimination, 71 Am Econ Rev 242, 243 (1981) ("Only an increase in total output above the single price monopoly level can serve to offset this distributional inefficiency. Thus, unless total output increases, monopolistic thirddegree price discrimination produces a net efficiency loss.").

208 The Robinson-Patman Act proscribes price discrimination where it may have a tendency to harm competition either in the upstream level between the seller and its competitors ("primary-line discrimination") or the downstream level ("secondary-line discrimination"). 15 USC \$ 13(a) (2000) (banning price discrimination "where the effect of such discrimination may be substantially to lessen competition or tend to create a monopoly in any line of commerce, or to injure, destroy, or prevent competition with any person who either grants or knowingly receives the benefit of such discrimination"). However, the former entails predatory pricing and the liability standard is the same as that for nondiscriminatory predation condemned under $\S 2$ of the Sherman Act. 15 USC \& 2 (2000). See Brooke Group Ltd v Brown \& Williamson Tobacco Corp, 509 US 209, 222 (1993) (noting that the standard under the Robinson-Patman Act of a "'reasonable possibility' of substantial injury to competition" is slightly more flexible than the Sherman Act's "dangerous probability of actual monopolization," but that "the essence of the claim under either statute is the same"). Thus the discrimination element is not really doing any work.

209 See, for example, Herbert Hovenkamp, Federal Antitrust Policy: The Law of Competition and Its Practice $\$ 14.6$ a at 523-24 (West 1994) ("The [Robinson-Patman] Act has been widely castigated by critics who see it as doing far more harm than good to the competitive process."). In implied acknowledgement of the anticompetitive nature of Robinson-Patman, the Justice Department long ago ceded its enforcement role to the Federal Trade Commission, which in turn rarely enforces the law. For all practical purposes, enforcement is a matter of private suits by competitors who, it hardly needs saying, are not reliable advocates for vigorous competition rules. 
If it is impossible to make such a judgment in the case of conventional goods, it is impossible to make it for intellectual property goods. ${ }^{220}$

No doubt Adobe earns more profit with price discrimination than it would if it were forced to sell its software program at a single price. Absent a showing that Adobe has market dominance, this is not a concern of antitrust policy. If it is not a concern of antitrust policy, it is hard to see the basis for objection in property law. The first sale doctrine is sometimes explained in terms of limiting the patent or copyright owner to a single return on its "monopoly"-the notion being that once the owner has realized a return from the first sale, its right to further returns has been exhausted. ${ }^{211}$ However, as I mentioned earlier, ${ }^{212}$ this explanation does not get us very far without some specification of what the acceptable returns to the owner should be. Not only do we have no measure of what is the appropriate limit, we have no clear standard for developing such a measure. In the Adobe case, for instance, forcing Adobe to sell its software at a single price by forbidding it the use of licensing restrictions to prevent arbitrage would likely reduce its overall profits; otherwise Adobe would not have adopted the price discrimination in the first place. The output effect is less certain. A single price would presumably be set somewhere between the educational and non-educational user prices, lowering demand for the former and increasing demand for the latter depending on their respective price elasticities. A reduction in Adobe's profits yields a reduction in producer surplus. The loss of producer surplus might be justified if it were offset by a gain in consumer surplus from increased output. However, the single price is as likely (some would

210 For contrasting views on the economic merits of discrimination in the context of intellectual property, compare Michael J. Meurer, Copyright Law and Price Discrimination, 23 Cardozo L Rev 55, 96-97 (2001) (arguing that discrimination in copyrighted works allows owners to capture excessive profit and thereby creates inefficient incentives to invest in such works), with William W. Fisher III, Property and Contract on the Internet, 73 Chi Kent L Rev 1203, 1234-40 (1998) (arguing that price discrimination for intellectual property expands output, enhances net consumer welfare, and reduces deadweight loss relative to the results of a uniform price). In the context of patented goods, Louis Kaplow, The Patent-Antitrust Intersection: A Reappraisal, 97 Harv L Rev 1813, 1874-75 (1984), argues that discrimination can lead either to expansion or contraction of output depending on market conditions.

211 See, for example, United States v Masonite Corp, 316 US 265, 277-78 (1942) (holding that the rights to the product manufactured under the patent were exhausted by the first sale, the test of which was "whether or not there has been such a disposition of the article that it may fairly be said that the patentee has received his reward for the use of the article"); Adams, 84 US at 456 (holding that, under the first sale doctrine, "the patentee had received his consideration, and [the machine] was no longer within the monopoly of the patent"); Platt \& Munk Co, Inc v Republic Graphics, Inc, 315 F2d 847, 854 (2d Cir 1963) ("[T]he ultimate question embodied in the "first sale' doctrine [is] - 'whether or not there has been such a disposition of the article that it may fairly be said that the patentee (or copyright proprietor) has received his reward for the use of the article."'), quoting Masonite, 316 US at 278.

212 See text accompanying note 166. 
say more likely) to reduce output as increase it. ${ }^{213}$ If that result obtains, the effect of banning the license restriction would be a reduction in social welfare (unless there is an offsetting distributional welfare gain that eludes me).

Finally, such a limit is unlikely to bear any relationship to the modes of marketing that are regulated by the first sale and misuse doctrines. Notice, for instance, that the first sale doctrine does not apply to rentals or leases; one might suppose that the underlying principle of limiting the owner's reward would apply whatever the form of the transaction. Yet in copyright law, the owner's rights are "exhausted" only with respect to the distribution right. The doctrine does not limit the owner's exclusive rights for public performance or preparation of derivative works. ${ }^{214}$ If some overriding public policy supports limiting the reward to the property owner, it is odd that this policy is so fitfully and inconsistently implemented.

\section{Controlling end users.}

As the Adobe case illustrates, price or nonprice restrictions on intermediate distributors aim to preserve a particular marketing plan for the product. Restrictions on end uses often serve broadly similar commercial purposes of supporting a particular marketing/pricing plan. ${ }^{215}$ For instance, the single-use license restriction in Mallinck-

213 An additional factor in the output calculation is that discounted sales to academic users might be a means of promoting sales in non-academic markets, in which case reduction in academic markets may not be offset by increased sales to non-academic users. The principal assumption here is that academic users - students most notably-learn to use Acrobat programs and carry that learning with them into professional and commercial markets after they graduate. To the extent that academic users perform this function, the discount can be justified as a payment for promotional services - analogous to so-called "functional discounts" given to retailers who perform promotional or other services. A similar purpose may also explain the dual distribution scheme in Clairol, $37 \mathrm{~Pa} \mathrm{D} \mathrm{\&} \mathrm{C} \mathrm{2d} \mathrm{at} \mathrm{434-35} \mathrm{(describing} \mathrm{the} \mathrm{marketing} \mathrm{strategy} \mathrm{that} \mathrm{es-}$ tablished separate prices and packaging for professional and retail bottles of hair dye). I am indebted to Tom Nachbar and Ed Kitch for pointing out the promotional aspect in these cases.

214 If I purchase a video tape or DVD, I can resell it, but I cannot exhibit it in public. Columbia Pictures Industries, Inc v Redd Horne, Inc, 749 F2d 154, 160 (3d Cir 1984) (holding that a store owner infringed public performance rights by exhibiting movie videos in rooms rented to its patrons). See also 17 USC $\S 106(5)$ ("[T] he owner of copyright ... has the exclusive rights to ... display the copyrighted work publicly.").

215 The animus of software licensing critics is invariably directed at commercial vendors seeking to promote some particular marketing plan, or protect some commercial interest in the product. However, noncommercial owners also have found end user license restrictions to their advantage. For example, the open source movement in computer software that promotes the use of software code without copyright restriction relies on licensing to accomplish this purpose. In order to perpetuate the openness of the code, users are asked to execute a "General Public License" (GPL) that gives the licensee the right to use, copy, modify, and distribute the code freely subject to the condition that any subsequent distribution must be made without copyright restrictions. There is no difference between a free GPL and a Microsoft End-User License Agreement. In both instances the purpose of the license is to create a servitude on the software. To 
rodt $t^{216}$ protected the patent owner/vendor's pricing scheme by preventing users from reusing the product's durable components. Analogous restrictions are common in software program licenses that restrict the use of the program to a single computer or limited number of computers. In both instances the license restriction might be superfluous to the extent the underlying patent or copyright limits reproduction of the product or some essential component, ${ }^{217}$ and one might fairly ask why the owner/vendor wants to replicate by license a right already possessed by patent or copyright. It might merely be a means of calling the user's attention to that copyright, or it might reflect a kind of "belt-and-suspenders" approach to protecting the property right. In any case, the user has no grounds for complaint since she gets what she paid for, even if she might have expected more.

A restriction designed simply to prevent proliferation of copies is one thing, but what about other use restrictions that affect the scope of the property rights' protection? Can a copyright owner restrict an end user's fair use rights? License restrictions on reverse engineering of intellectual property works, a ubiquitous feature of shrinkwrap software licenses, raise that question. ${ }^{218}$ In the copyright context, courts

date, there has been no formal legal enforcement of the GPL, but this may change as a consequence of a recent copyright infringement claim by The SCO Group (SCO) against Linux users and distributors. SCO claims that Linux contains elements of Unix code that have been illegally copied in violation of SCO's copyright. IBM, one of the defendants, has counterclaimed, inter alia, that SCO itself distributed Linux under the GPL and is bound by its terms not to assert a copyright claim. See generally Jonathan Zittrain, Normative Principles for Evaluating Free and Proprietary Software, 71 U Chi L Rev 265 (2004); Stephen Shankland, Big Blue Files Counterclaims against SCO, C/Net News.com (Aug 7, 2003), online at http://news.com.com/2100-10165060965.html (visited Aug 5, 2004)

$216976 \mathrm{~F} 2 \mathrm{~d} 700$. See discussion in text accompanying note 53.

217 In the patent case the question is whether replacement of a component of the product constituted a forbidden reproduction or permissible "repair" of the product. Id at 709. In copyright, because every loading of the program into a computer's random access memory (RAM) makes a copy, see, for example, MAI Systems Corp v Peak Computer, Inc, 991 F2d 511, 518 (9th Cir 1993), use on multiple platforms is an infringement unless expressly authorized by the original transfer or authorized by the Copyright Act. Section 117(a) of the Act does authorize the owner of a copy of the program to make an additional copy where it is an "essential step in the utilization of the computer program in conjunction with a machine" and where a new copy is made for archival purposes. 17 USC $\S 117$ (a)(1)-(2). It does not purport to authorize making copies for use of a program on multiple platforms, however. Of course, the first sale doctrine has no application here since it exhausts the original owner's exclusive right to control distribution, not his right to control any of the other exclusive rights granted under $\S 106-$ in this case, the reproduction right. 17 USC $\$ 106(1)$.

218 See generally Pamela Samuelson and Suzanne Scotchmer, The Law and Economics of Reverse Engineering, 111 Yale L J 1575, 1626-30, 1660 (2002) (arguing that if the intellectual property regime is well defined, then contracts limiting reverse engineering should not be enforced); Julie E. Cohen, Reverse Engineering and the Rise of Electronic Vigilantism: Intellectual Property Implications of "Lock-Out" Programs, 68 S Cal L Rev 1091 (1995) (examining how copyright and patent overlap as related to computer programs and arguing for the allowance of reverse engineering as "fair use"); Rice, 53 U Pitt L Rev 543 (cited in note 201) (arguing that intellectual property law preempts state contract law on the enforcement of license restrictions on 
have recognized a fair use privilege to engage in reverse engineering where necessary to gain access to noncopyrightable elements of the code when it does not involve extensive copying of copyrighted elements. ${ }^{219}$ Like most commentators, ${ }^{220}$ I think the courts are correct. In-

reverse engineering). I here focus on copyrighted software products, though the same issue can arise with patented software. See, for example, Bowers v Baystate Technologies Inc, 320 F3d 1317, 1321-22 (Fed Cir 2003), cert denied, 539 US 928 (2003) (involving reverse engineering of computer-aided design programs that were both copyrighted and patented). In the case of patented products, the need for reverse engineering may be avoided to the extent the requisite information about the functionality of the product is coextensive with the information required to be disclosed by the patent application. See Samuelson and Scotchmer, 111 Yale L J at 1584 ("In theory, there should be no need to reverse-engineer a patented invention to get information about how to make it because the patent specification should inform the relevant technical community of how to make the invention, and indeed the best mode of making it."). However, in the case of software programs it is not required that the patent application include the source code. See $R o$ botic Vision Systems, Inc v View Engineering, Inc, 112 F3d 1163, 1166 (Fed Cir 1997) ("[W]hen disclosure of software is required, it is generally sufficient if the functions of the software are disclosed, it usually being the case that creation of the specific source code is within the skill of the art.").

219 Reverse engineering of copyrighted software constitutes an infringement only to the extent that it entails a reproduction of protected work. The initial reproduction of the software when it is loaded into memory presumably is privileged as an "essential step in the utilization of the computer program" under 17 USC $\$ 117$. See Vault Corp v Quaid Software, Ltd, 847 F2d 255, 261 (5th Cir 1988) (holding that utilization is not limited to uses intended by the software vendor). However, insofar as the reverse engineering process involves additional copying, it will be an infringement unless the copying is privileged as a fair use. The leading case is Sega Enterprises Ltd $v$ Accolade, Inc, 977 F2d 1510, 1527-28 (9th Cir 1992) (allowing intermediate copying as fair use to allow reverse engineering to discover unprotected elements of the code, but noting that fair use would not protect use of the protected elements in a competitor's finished product). Since Sega, all courts considering the issue have recognized the fair use privilege in principle, though not all have found the requisite criteria satisfied. Compare, for example, Sony Computer Entertainment, Inc v Connectix Corp, 203 F3d 596, 602-08 (9th Cir 2000) (finding a fair use privilege), with Lexmark International, Inc v Static Control Components, Inc, 253 F Supp 2d 943, 96062 (ED Ky 2003) (holding that reverse engineering did not satisfy fair use criteria).

The lawfulness of reverse engineering of patented works presents somewhat different doctrinal questions from those involved in the case of copyrighted works, though the underlying policy issues are similar. Because patent law contains no fair use privilege, the question is simply whether the process of reverse engineering entails an unauthorized use or making of the patented article within the meaning of 35 USC $\$ 271$ (a). In the case of physical products, the mere disassembly of a patented article normally would be privileged under the implied right to use or first sale doctrine. Samuelson and Scotchmer, 111 Yale L J at 1584 (cited in note 218). However, Julie Cohen and Mark Lemley conclude that in the case of software patents decompiling the object code probably does infringe, although they set forth several arguments for allowing decompiling. See Cohen and Lemley, $89 \mathrm{Cal} \mathrm{L} \mathrm{Rev} \mathrm{at} \mathrm{23-28} \mathrm{(cited} \mathrm{in} \mathrm{note} \mathrm{60).} \mathrm{This} \mathrm{conclusion} \mathrm{appears}$ to be based on the assumption that decompiling the program entails an unauthorized "use" of the patented work. However, even if decompiling is not privileged (under the first sale doctrine or implied license to use) one could argue that running the program through a decompiler does not itself "read" on the patent claims, which are made not for the program itself but for some end purpose or process. Whether the software code by itself can be patented remains doubtful, though this appears now to be a formalism. See Mark A. Lemley, et al, Software and Internet Law 163-81 (Aspen 2d ed 2003) (discussing cases after Diamond v Diehr, 450 US 175 (1981)). In other words, if the program is not run to achieve the purpose of the claims, it might not be an infringement. Curiously there seems to be no precedent directly on point.

220 See Cohen and Lemley, 89 Cal L Rev at 16 n 53 (cited in note 60) (citing cases and 
deed, courts probably have been overly cautious in applying fair use criteria, but this is a tangential matter. ${ }^{21}$ The important question here is not whether fair use justifies reverse engineering but whether a license restriction against it should be enforceable. As with other restrictions, answering this question requires consideration of two quite distinct questions. One is whether contract enforcement of a term is preempted by copyright (or patent) law; the other is whether enforcement conflicts with antitrust policy.

In ProCD, ${ }^{22}$ Judge Easterbrook thought the preemption issue was settled by the Supreme Court's decision in Kewanee Oil Co $v$ Bicron Corp, ${ }^{2,3}$ holding that contracts prohibiting disclosure of trade secrets were not preempted by patent law. ${ }^{24}$ Kewanee Oil allowed the owner of a patentable invention to choose between seeking to protect the invention as a trade secret (in this case by means of an employment contract forbidding disclosure) or by patent. The central question for the Court was whether there is a substantial risk that inventors would seek trade secret protection rather than patent protection, thereby undermining the policy of public disclosure in return for patent protection. The Court considered three types of invention: those believed by the inventor to be not patentable, those considered to be of doubtful patentability, and those believed to be clearly patentable.

commentators supporting reverse engineering). Maureen O'Rourke has proposed a limited fair use in patent law, which would allow, among other things, reverse engineering of software patents. Maureen A. O'Rourke, Toward a Doctrine of Fair Use in Patent Law, 100 Colum L Rev 1177,1227 (2000).

221 The Copyright Act lists four components to a fair use analysis:

(1) the purpose and character of the use, including whether such use is of a commercial nature or is for nonprofit educational purposes; (2) the nature of the copyrighted work; (3) the amount and substantiality of the portion used in relation to the copyrighted work as a whole; and (4) the effect of the use upon the potential market for or value of the copyrighted work.

17 USC \$ 107 . If privileged reverse engineering allows the user to access only those elements of the code that are not protected by copyright, as held in Sega Enterprises, 977 F2d at 1528, and there is only intermediate, incidental copying of the protected elements, most of these criteria simply become irrelevant. If the reverse engineer merely accesses those things not within the owner's property right claim in the first place, the owner does not have any property right basis for complaining that the resultant product hurts him in the marketplace when that product itself does not infringe. A similar argument applies to the patent case, where reverse engineering can be seen as simply a means of obtaining information that ought to be publicly disclosed in the patent application but is not. See Cohen and Lemley, $89 \mathrm{Cal} \mathrm{L} \mathrm{Rev} \mathrm{at} \mathrm{24-27} \mathrm{(cited} \mathrm{in} \mathrm{note} \mathrm{60)}$ ("[S]oftware patent owners will get a windfall if they can prevent reverse engineering: the right to preclude access to their invention and therefore to prevent others from improving it, despite the clear intent of the patent statute to the contrary.").

22286 F3d 1447. See text accompanying notes $99-100$.

223416 US 470 (1974) (discussing the protection of trade secrets related to the growth a type of synthetic crystal). Rice, 53 U Pitt L Rev at 577-88 (cited in note 201), provides an extended and careful critique of Kewanee.

224416 US at $491-92$.

225 Id at 484-90. 
In the first two cases the Court found no conflict with the disclosure policy because of the unlikelihood that the inventor would apply for a patent or a valid patent would issue. The third case presented a somewhat more difficult question because it is in the case of clearly patentable inventions that the interest in public disclosure is strongest. However, even here the Court concluded that it would be the rare inventor who would choose the weaker, less reliable protection of trade secret law over patent protection. ${ }^{226}$ Thus allowing trade secret protection would encourage the "development and exploitation of those items of lesser or different invention than might be accorded protection under the patent laws." ${ }^{227}$ By providing a low-cost alternative form of protection for information with relatively low or nondurable value, trade secret protection lowers costs for both the owner and for the patent system as a whole. ${ }^{228}$

The Supreme Court has not considered whether trade secret law is preempted by the Copyright Act. However, three circuit courts have expressly held it is not, allowing the owner of a copyright to obtain trade secret protection for copyrighted software code. ${ }^{229}$ More recently the Federal Circuit reached the same result by holding that license restrictions forbidding reverse engineering could be enforced by a breach of contract claim - the court expressly relying on the private ordering rationale of ProCD in holding that contract actions are not preempted by the Copyright Act. ${ }^{20}$ Where trade secret law applies,

226 Id at 489-90.

227 Id at 493.

228 See Edmund W. Kitch, The Nature and Function of the Patent System, $20 \mathrm{~J}$ L \& Econ 265, 288 (1977).

229 See Trandes Corp v Guy F. Atkinson Co, 996 F2d 655, 660 (4th Cir 1993) ("[T]he breach of a duty of trust or confidentiality comprises the core of actions for trade secret misappropriation, and 'supplies the "extra element" that qualitatively distinguishes such trade secret causes of action from claims for copyright infringement that are based solely upon copying."'), quoting Computer Associates International, Inc v Altai, Inc, 982 F2d 693, 717 (2d Cir 1992); S.O.S., Inc v Payday, Inc, 886 F2d 1081, 1090 n 13 (9th Cir 1989) ("Since the California statute pleaded in this case does not involve a legal or equitable right equivalent to an exclusive right of a copyright owner under the Copyright Act, but only prohibits certain means of obtaining confidential information, its application here would not conflict with federal copyright law.").

230 Bowers, 320 F3d at 1324-25. The case involved claims of patent infringement, copyright infringement, and violation of contract. On the latter two claims, the Federal Circuit applied the law of the circuit where the action arose, the First Circuit, and found both infringement and contract violation. On the contract claim, the court rejected the defendant's claim of preemption, basing its decision on the First Circuit's decision in Data General Corp v Grumman Systems Support Corp, 36 F3d 1147, 1164-65 (1st Cir 1994) (holding that federal copyright law did not preempt the state trade secret claim). However, the court's reliance on that decision is somewhat circuitous because the issue was not squarely presented in Data General. The Federal Circuit relied more directly on ProCD, 86 F3d 1447, which had cited Data General, giving rise to an inference that the First Circuit would follow ProCD in holding that contracts are not preempted by $\S 301$ of the Copyright Act. Bowers, 320 F3d at 1325 ("This court believes that the First Circuit would follow the reasoning of ProCD and the majority of other courts to consider this issue."). Compare DVD Copy Control Association, Inc v Bunner, 31 Cal 4th 864, 4 Cal Rptr 3d 69, 91 
however, the private ordering argument seems both unnecessary and misleading since trade secrets are protected as a form of property right. Although trade secret protection is often created by means of a contract forbidding disclosure, once the trade secret exists it can be enforced against noncontracting third persons who have notice of the secret. ${ }^{231}$ In this way and to this extent, trade secret law allows the creation of a property right, qua servitude, in the information. ${ }^{222}$ Whether such a servitude should be enforced should not turn on the arbitrary semantic distinction between private and public ordering, but whether the policy of public disclosure for information about patentable products or public access ("fair use") to copyrighted information is sufficiently strong to override the rights.

No unequivocally correct answer to that question exists. Allowing parties to contract around limitations of the patent and copyright laws undermines a central purpose of those laws - to achieve a balance between private and public rights in information. However, preempting all alternative forms of protecting private rights in information might not have the effect of enhancing public access; it might simply lead to other forms of private control that do not rely on legal enforcement. ${ }^{233}$ Also, increasing the preemptive exclusivity of copyright or patent laws might increase the costs of those systems to the extent they would have to bear more of the burden of protection. As noted above, one argument for allowing trade secrets to be protected independent of the patent system is to provide a low-cost alternative to the patent system for information that has relatively low or nondurable value. ${ }^{24}$

A possible compromise might be to allow an accommodation for individual contractual restrictions, but draw the line at industrywide licensing of the kind practiced by the software industry. One argument for such a compromise is that an industrywide practice implies a kind of norm that can no longer be rationalized under the rubric of "private ordering," but that argument simply perpetuates unhelpful for-

(2003) (enjoining the future disclosure of a trade secret by a person who had notice that the secret had been acquired in violation of a license provision barring reverse engineering).

231 See Restatement (First) of Torts $\$ 757$ (1939) (noting that liability attaches to the knowing disclosure of a trade secret whether knowledge of the secret was acquired through illegal action or accident); DVD Copy Control Association, 4 Cal Rptr 3d at 84-85 ("[A] person who knowingly exploits the illegal acquisition of property owned by another should be in "no better position than' the illegal acquirer himself.").

232 See, for example, Colgate-Palmolive Co v Carter Products, Inc, 230 F2d 855, 865 (4th Cir 1956), citing Herold v Herold China \& Pottery Co, 257 F 911, 913 (6th Cir 1919):

The rule is well settled that secret formulas and processes ... are property rights which will be protected by injunction, not only as against those who attempt to disclose or use them in violation of confidential relations or contracts express or implied, but as against those who are participating in such attempt with knowledge of such confidential relations or contract.

233 See Part IV, particularly text accompanying notes $241-45$.

234 See text accompanying note 228 . 
malism. A more plausible argument would be that an industrywide practice involves a more substantial threat to the statutory design of copyright and patent systems. ${ }^{235}$ The idea of drawing the line at industrywide license restrictions is an appealing compromise but one not easy to implement. The industrywide practices are not, after all, the product of collective action, so how would the law decide who, or how many, are allowed to impose the restriction? Presumably the law would have to ban all or none, which is inconsistent with the purpose of attacking only industrywide practices.

Setting aside conflicts with copyright policy, license restrictions against reverse engineering might be thought to conflict with competition policy to the extent the restrictions have the effect of unreasonably handicapping new entry by precluding an important tool for competitive innovation. The trade restraint issue is at least as complicated as the preemption issue, however. Reverse engineering can reduce the costs of competitive innovation, but can also undermine the incentive to invest in the creation of productive assets. It is no easy matter to determine which effect will prove more important to competition in the long run. ${ }^{236}$ In this respect, the cases of intellectual and common law property rights are similar. In both cases the usual rules of competition generally do not require competitors to cooperate or share their productive assets, tangible or intangible. ${ }^{237}$ This includes trade secrets, which are generally thought to be a positive tool of competitive rivalry. ${ }^{238}$ The fact that trade secret law does not necessarily prevent reverse engineering does not undermine this point; if trade secret pro-

235 See Rice, 53 U Pitt L Rev at 587 (cited in note 201) (arguing that an industry-wide licensing scheme could become "perpetual quasi-patent protection for software trade secrets"). Properly understood, this consideration is not a matter of whether licenses are negotiated or not. As I argued earlier, see text accompanying note 93 , the fact that most buyers cannot bargain over shrinkwrap licenses is no more important than the fact that they cannot bargain over their groceries. The reason why one might consider the industrywide character of the practice on the question of preemption is not because it unfairly limits consumer choice - the standard complaint against adhesion contracts - but because a widespread practice involves a more substantial conflict with the statutory regime.

236 The tradeoffs are explored in Samuelson and Scotchmer, 111 Yale L J at 1585-90 (cited in note 218) (concluding that "a legal rule favoring reverse engineering of traditional manufactured products is economically sound").

237 See, for example, Colgate, 250 US at 307 ("In the absence of any purpose to create or maintain a monopoly, the act does not restrict the long recognized right of trader or manufacturer engaged in an entirely private business, freely to exercise his own independent discretion as to parties with whom he will deal.").

238 See Kewanee, 416 US at 483 (noting the importance of protecting trade secrets such as customer lists or advertising campaigns to "constructive competition"); Rockwell Graphic Systems, Inc v DEV Industries, Inc, 925 F2d 174, 180 (7th Cir 1991) (Posner) ("[T]rade secret protection is an important part of intellectual property, a form of property that is of growing importance to the competitiveness of American industry."). 
tection promotes competition as claimed, license agreements that serve this purpose would seem to be no less procompetitive.

To be sure, antitrust law sometimes requires cooperation among firms in the case of monopolists, particularly those in control of socalled essential facilities, but the mere fact that a firm possesses an asset or information the sharing or disclosure of which would aid competition cannot be sufficient grounds for legal compulsion. ${ }^{299}$ If it were, both patent and copyright regimes would cease to be exclusive property rights regimes in any context in which the exercise of exclusionary rights would be inconvenient to competition. This is not a question of whether intellectual property rights should be subordinate to antitrust policy. Clearly they are subordinate, in the same way and to the same degree that common law property rights are subordinate. ${ }^{240}$ But the antitrust constraint is an exogenous policy constraint on the property right and not part of the definition of the property right itself. To the extent patent and copyright regimes create exclusive rights similar to those of common law property, antitrust policy should not alter those property rights except where they are accompanied by market power and antitrust misconduct. The mere existence of restrictive licensing, without more, is insufficient to justify antitrust condemnation.

In the end, then, we seem to be left with not much more than some vague notion that there must be limits in the use of contract to reshape property rights but no workable means of defining those limits. Perhaps, though, it does not matter, for in the realm of digital property where the problem primarily arises, owners now have other means of exercising control.

239 See generally Robinson, 87 Cornell L Rev 1177 (cited in note 39) (reviewing antitrust policies and the doctrine on forced dealing).

240 Some special tension is often observed between intellectual property rights and antitrust, particularly on the question of whether there can be antitrust liability for refusal to license competitors despite the general principle that copyright and patent owners are not generally required to license others. See, for example, Image Technical Services, Inc, v Eastman Kodak Co, 125 F3d 1195, 1215 (9th Cir 1997) (noting the "obvious tension" between antitrust and patent law in that "[o]ne body of law creates and protects monopoly power while the other seeks to proscribe it"), citing United States v Westinghouse Electric Corp, 648 F2d 642, 646 (9th Cir 1981). However, this observation just reflects the conflation of property rights and monopoly noted earlier. For antitrust purposes, the rights of intellectual property owners are essentially similar to those of common law property owners. See 1995 Department of Justice and Federal Trade Commission Federal Antitrust Guidelines for the Licensing of Intellectual Property $\$ 2.0$ (1995), reprinted in American Bar Association Section of Antitrust Law, The Federal Antitrust Guidelines for the Licensing of Intellectual Property: Origins and Applications 1101 (ABA 2d ed 2002). For both types of property, there is no general duty to deal, but there also is no general immunity from antitrust liability for anticompetitive conduct (which, in exceptional cases, may involve a refusal to deal). See Robinson, 87 Cornell L Rev at 1209-11. 


\section{IV. "HARdWIRED" SERVITUdES}

To this point I have focused on whether the law should enforce contractually created servitudes on personal property. But what if no legal enforcement is required? What if the desired restrictions are simply hardwired into the product itself? Chafee could not have appreciated this issue because the product-design opportunities for accomplishing this objective were very limited in his era. Today, in the age of digital property, the architectural option is an important one. In the digital age, Lawrence Lessig tells us, "code is law.",241 Instead of seeking to impose and enforce restrictions by means of contract or property law, the owner of digital property can encode the restrictions into the object itself. Digital rights management tools are rapidly becoming a standard means of enforcing restrictions on the use or copying of such digital products as computer software, ${ }^{242}$ DVDs, ${ }^{243}$ and ebooks. ${ }^{24}$ These self-enforcement mechanisms economize on enforce-

241 Lawrence Lessig, Code and Other Laws of Cyberspace 6 (Basic 1999).

242 For example, Microsoft's Windows XP software contains so-called "Windows Product Activation" code designed to cut down on casual sharing of the program. When XP is loaded, it locks a product identification number assigned to each copy of the program onto the PC on which it is installed. This creates an activation code for that PC; the user has thirty days to register the activation code with Microsoft, either by phone or over the internet. Microsoft can then scan its database of activation codes to ensure that the software has not been installed on more computers than are authorized by the program license. See Windows XP Product Activation (updated Aug 29, 2002), online at http://www.microsoft.com/windowsxp/evaluation/features/ activation.mspx (visited Aug 5, 2004). Intuit's latest version of TurboTax contains a similar activation feature. See Walter S. Mossberg, Of Top Tax Programs, One Has Developed an Insulting Approach, Wall St J B1 (Jan 30, 2003) ("Users must contact Intuit to 'activate' the software, a process that limits full use of TurboTax to a single PC. To enforce this system, Intuit secretly installs third-party monitoring software on users' PCs.").

243 An encryption system - the "content scrambling system" or "CSS"-is used by the movie industry to prevent copying of DVDs. The encryption system works with authorized DVD players that contain decryption technology to allow the movie to be displayed on a television or computer screen but not to be copied. For more on CSS, and its evil twin, "DeCSS" - an illegal tool for circumventing the encryption, see Universal City Studios, Inc v Corley, 273 F3d 429, 45360 (2d Cir 2001) (upholding an injunction against disseminating a copy of DeCSS in violation of the Digital Millennium Copyright Act).

244 Adobe's ebook software is illustrative. Publishers use Adobe's Content Server (similar in function to Adobe Acrobat used to format documents for electronic distribution) to format books to be read by means of Adobe Acrobat eBook Reader (a free reader similar in function to the more familiar Adobe Reader used to read Acrobat formatted documents). Using the formatting software, publishers can regulate copying, printing, "lending," and reading audibly by means of a speech synthesizer program. See United States v Elcom Ltd, 203 F Supp 2d 1111, 1122-42 (ND Cal 2002) (upholding a criminal indictment under the Digital Millennium Copyright Act for making and distributing a product designed to circumvent the restrictions). Other publishers distribute similar formatting programs, though they all serve basically the same purpose. The types of restrictions publishers use vary. For example, an ebook version of Dan Brown, The Da Vinci Code (Doubleday 2003), disallows printing, copying, lending, and reading aloud. See EBooks.com, online at http://www.ebooks.com/books/149511.smm (visited Aug 5, 2004). If these restrictions are deemed too onerous, the user might want to try Sari Locker, The Complete Idiot's Guide to Amazing Sex (Alpha 1999), which allows unlimited printing, copying, and reading 
ment costs, among other things. ${ }^{245}$ That virtue is their vice as well: they circumvent the legal process that provides the means for an independent verification that the use restrictions are allowed by law. In the case of contractually imposed restrictions, a person seeking to avoid the restriction can at least raise fair use or other public policy as a defense to an action to enforce the license. ${ }^{246}$ Where the restriction is automatically enforced, the opportunity to raise a legal defense is lost. ${ }^{247}$

The problem with self-enforcement mechanisms is more than retention of legal defense rights. I suspect the common aversion to such mechanisms arises not from the fact that they work imperfectly - by foreclosing valid legal defenses-but from the fact that they work too perfectly, eliminating the freedom to cheat. ${ }^{2+8}$ This is not uniquely a matter of intellectual property. I walk my dog through open fields in knowing, but guiltless, defiance of no-trespassing signs posted on the property. Having satisfied myself that I am a moral person, and that the no-trespassing signs are not really intended to prevent the harmless exercising of one's dog, I would feel aggrieved if those signs were equipped with automatic sensing machines that could detect and record my presence. That confession being made, I am not sure what to make of it. ${ }^{249}$ No doubt it is socially healthy that we are not called to account for every minor deviation from the letter of the law, but it is hard to craft a legal rule that says cheating is allowed provided it is not excessive. It certainly would not occur to me to claim that I was the victim of "electronic slavery," the accusation Ralph Nader leveled on one entrepreneurial car dealer who in order to enforce interest pay-

aloud. See EBooks.com, online at http://www.ebooks.com/books/137361.smm (visited Aug 5, 2004).

245 For an overview of self-help systems and the controversies surrounding them, see generally Kenneth W. Dam, Self-Help in the Digital Jungle, 28 J Legal Stud 393, 397 (1999) ("[A]llowing people to protect by their own means what they create is usually socially optimal where the law does not provide for a cheaper, more effective remedy."). As Dam notes, his favorable view of such systems is not widely shared among intellectual property scholars. Id at 395 .

246 I am assuming here that an action to enforce the license would be seen as equivalent to an action for infringement and hence preempted by the Copyright Act. 17 USC § 301(a) (" $[\mathrm{N}] \mathrm{o}$ person is entitled to any such right or equivalent right in any such work under the common law or statutes of any State."). If, following cases like ProCD, license or contract claims are considered to be generically different from copyright infringement actions, then fair use would not come into play. Note, however, that a court could still invoke common law policies-such as unconscionability - to withhold enforcement.

247 "Electronic self-help" measures are banned in "mass-market" license agreements under $\S 816$ (b) of UCITA. Whatever the wisdom of this safeguard, it no longer matters since UCITA itself is moribund. See note 89 .

248 The point is briefly but eloquently expressed by David Weinberger, Copy Protection Is a Crime, Wired 089 (June 2003).

249 Probably I would sputter something like, "It is an invasion of privacy," but needless to say, that would beg the question of whether my right to privacy trumps the owner's right to enforce her property rights. 
ments by customers installed a device that prevented the car from starting if a payment was missed.

Some counterstrategies may guard against the tyranny of selfhelp devices. Reciprocal self-help has been suggested. If the code offends thee, hack it off. ${ }^{251}$ Quite aside from the fact that the Digital Millennium Copyright Act (DMCA) makes this circumvention strategy legally risky, it does not seem sensible. If it does not lead to a lot of hackers going to jail, it will lead to a socially wasteful technological

250 See Holman W. Jenkins, Jr., Business World: Give the Poor a Little Credit, Wall St J A31 (Apr 19,2000) (arguing that the technology is a good thing because it allowed a car dealer to go into inner city neighborhoods and make loans to risky customers who otherwise would not be able to buy cars). Reportedly the delinquencies dropped to almost zero, which suggests that this wasn't an egregious imposition on the customers. However, this did not mute Nader's criticism or deter a lawsuit against the dealer. Id.

251 See Julie E. Cohen, Copyright and the Jurisprudence of Self-Help, 13 Berkeley Tech L J 1089, 1141 (1998) ("A 'right of fair breach' is meaningless unless it includes a right to effectuate the breach - a right to hack the digital code that implements and enforces the challenged restriction.").

252 Broadly, the DMCA, 17 USC \& 1201 (2000), prohibits efforts to circumvent protective technologies designed to restrict access or use of a copyrighted product. The Act contains three provisions targeted at the circumvention of technological protections. The first, $\S 1201(\mathrm{a})(1)(\mathrm{A})$, prohibits the act of circumventing a technological measure that effectively controls access to a copyrighted work. The second, $\S 1201$ (a)(2), prohibits manufacturing, importing, offering to the public, providing, or otherwise trafficking in any device that is primarily for the purpose of circumventing an access control measure or a device that has only limited commercially significant purpose other than for circumvention. The third, $\$ 1201(\mathrm{~b})(1)$, is similar to $\$ 1201(\mathrm{a})(2)$, except that it proscribes manufacturing of devices designed to circumvent anti-copy controls (any control designed to protect the rights of the copyright owner). The law contains a number of exceptions. For example, there is an exception for individuals using circumvention technology for the sole purpose of trying to achieve interoperability of computer programs through reverse engineering, $\$ 1201$ (f), and an exception for encryption research aimed at identifying flaws in encryption technology, $\S 1201(\mathrm{~g})$. Probably the most noteworthy exclusion from the DMCA's broad prohibitions against circumvention is $\S 1201(\mathrm{a})(1)(\mathrm{B})$, which excludes individual acts of circumventing anti-copy controls for the purpose of exercising their noninfringing privileges under the copyright law. For instance, one can circumvent an anti-copy control that prevents a user from exercising her fair use privileges. This is, however, a quite limited exception; it does not permit circumvention of access controls. Thus, the reverse engineering of the lockout code that defendants used in Sega Enterprises, Ltd v Accolade, Inc, 977 F2d 1510 (9th Cir 1992), to gain access to the platform in order to reverse engineer that code presumably would violate the DMCA (enacted after the decision), notwithstanding that the reverse engineering of the use controls was held to be a fair use. Id at 1527-28 ("[W]here disassembly is the only way to gain access to the ideas and functional elements embodied in a copyrighted computer program and where there is a legitimate reason for seeking such access, disassembly is a fair use of the copyrighted work, as a matter of law."). See Lexmark International, Inc v Static Control Components, Inc, 253 F Supp 2d 943, 970-71 (ED Ky 2003) (finding reverse engineering to circumvent an access control a violation of the DMCA). The DMCA also makes it unlawful to make or distribute circumvention devices designed to permit other persons to exercise their fair use privileges. The constitutionality of the DMCA has been challenged (unsuccessfully) on this ground, among others. See Elcom, 203 F Supp 2d at 1130-32 (rejecting a First Amendment challenge based on the claim that the DMCA does not adequately recognize fair use rights). See also Corley, 273 F3d at 452-59 (rejecting First Amendment challenges on both general code-as-speech and fair use grounds to the DMCA as applied to distribution of decryption code).

253 In addition to civil damages, the DMCA provides for criminal penalties. A first-time of- 
"arms race" between content producers and hackers of the kind that we see taking place with online file-sharing strategies and counterstrategies. ${ }^{244}$

Another possibility is some kind of regulatory intervention, perhaps by the Federal Trade Commission (FTC) on the grounds that these restrictions constitute an unfair trade practice. ${ }^{2 s 5}$ That option also leaves a lot to be desired. In cases where the restrictions constitute exclusionary behavior by firms with market power, antitrust enforcement may be appropriate, though the problem of formulating a remedy is daunting. It is no easy matter to formulate appropriate legal standards to govern product design, particularly in a field that is technologically advanced and constantly evolving. United States $v$ Microsoft Corp ${ }^{256}$ illustrates. The D.C. Circuit was asked to rule that the physical integration of Microsoft's browser and operating system was simply a form of an illegal tying arrangement. The court ultimately allowed this practice to be considered as part of an overall claim of monopolization, but it refused to single out the practice for per se condemnation because of the difficulties of determining the appropriate architecture for computer platforms. ${ }^{257}$

We do, of course, have a variety of regulatory controls dealing with safety, health, and environmental aspects of products and the processes by which they are made. Most of these controls do not significantly change the basic design or functionality of the product, however. (Automobile safety or fuel efficiency regulations, for instance, operate only at the margins of the industry's design choices.) In those exceptional cases where the government has undertaken extensive redesign of industrial processes - as with technology-forcing

fender, committing a willful violation for commercial or financial advantage, can be fined up to $\$ 500,000$ and imprisoned for five years. The penalties are doubled for repeat offenses. 17 USC $\S 1204(\mathrm{a})$.

254 See, for example, Brian Krebs, Copyright in the Digital Age: Online Piracy Spurs HighTech Arms Race, washingtonpost.com (June 26, 2003), online at http://www.washingtonpost.com/ ac2/wp-dyn? pagename=article \&node $=$ \&contentId=A34439-2003Jun26 (visited Aug 5, 2004) ("[E]ven as the entertainment industry steps up its push to rid the online world of piracy, techsavvy file sharers are devising new ways to avoid getting caught.").

255 Cohen, 13 Berkeley Tech L J at 1140 (cited in note 251), suggests this possibility only to reject it on the grounds that the FTC "has neither the jurisdiction nor the expertise to preserve the substantive balance mandated by federal copyright law." Id. This statement may be correct but it misses the larger point, which goes not to the FTC's jurisdiction or expertise to enforce copyright policy but to the basic competence to determine what is and what is not a legitimate product design. Cohen apparently has in mind a simple software measure the sole purpose of which is to deprive the buyer of rights under the copyright law. However, any regulatory strategy must consider the daunting prospect of dealing with more complex questions of product design.

256253 F3d 34, 101-07 (DC Cir 2001).

257 Id at 89-96 (arguing that the lack of past cases involving technologically integrated products, the common use of integration even among firms lacking market power, and the ubiquity of bundling make rule of reason analysis necessary but difficult). 
environmental regulations-the results have been controversial to say the least. Before undertaking that kind of ambitious intervention one would want to be very clear about what the design objectives are and whether they can be effectively accomplished by regulatory specification.

Consider the ebook example. As noted earlier, it is common for ebooks to use digital management tools to control the use and transfer of the ebook. To prevent widespread sharing of ebooks, a publisher can format the book to limit printing, copying, or "lending" the book to others. Such controls plainly limit fair use and first sale privileges. Suppose Congress outlaws the manufacture of any device designed to expand the rights of publishers or to limit the rights of users under the copyright law. 258 The ebook publisher dutifully removes the format controls that specifically control use and instead formats it in a way that limits the lifetime of the book - allowing it to be read, say, once or twice. This practice is already being explored for DVDs, ${ }^{299}$ and it is currently in use by some publishers of digital legal databases. ${ }^{260}$ This will not prevent all sharing or resale but it will certainly limit it. ${ }^{261}$ Would

258 This is implausible given the DMCA, through which Congress enacted a policy that marches in the opposite direction.

259 Buena Vista Home Entertainment (a Disney subsidiary) is engaged in market tests of a DVD that can only be played for up to forty-eight hours after being removed from its cover. The idea behind these "disposable" DVDs is to eliminate the cumbersome rental and return of permanent DVDs. The self-destruct mechanism involves using a special polymer for the DVD which becomes opaque after exposure to air and thus cannot be read by the laser in the disc player. See This Movie Will Self-Destruct, Economist 72 (Jul 12-18, 2003). The initial trials showed a mixed reception by customers-characterized by Buena Vista as ranging between "a phenomenal success and a disappointment." Industry Notes, Warren's Consumer Electronics Daily (Mar 26, 2004). The trials are being extended to new markets, and Flexplay, which makes the disposable discs, is trying to get other movie studios interested in the technology. See Paul Sweeting, Disney is EZ in Four More Cities, Video Bus (Mar 15, 2004). In the meantime, environmentalists are complaining about the waste resulting from trashed DVDs. Katie Dean, Disposable DVDs Go to the Dumps, Wired News (May 21, 2003), online at http://www.wired.com/news/print/ 0,1294,58906,00.html (visited Aug 5, 2004).

260 Some subscription-based legal sources available in digital form, such as $\mathrm{CCH}$ and BNA, contain termination dates that prevent the software from loading into the computer beyond set dates. The BNA user license explains that " $[t]$ o prevent inadvertent reliance on outdated information, each BNA CD-ROM is rendered inoperable after a certain period which may vary depending on the particular Licensed Product." Terms and Conditions for Use of BNA Electronic Products (License Terms) II 12 (2004), online at http://www.bna.com/corp/license.htm (visited July 20, 2004). BNA's admirable concern to prevent "inadvertent reliance" by the user also serves the convenient purpose of clearing the overhang of old CDs that, while partly outdated, may be "good enough for government work," as they say.

261 The publisher might need to adjust the price to the extent that reduced durability affects the consumer's demand. See Richard Schmalensee, Regulation and the Durability of Goods, 1 Bell J Econ \& Mgt Sci 54, 55 (1970) ("The demand for a durable good depends upon both initial purchase price and durability, since both influence the cost of utilizing the services of the good."). Note, however, that this price adjustment is already implicit in the ebook publisher's previous decision to impose formatting controls that have a similar effect. In either case the publisher makes a product design decision based on the demand estimates for different product configura- 
such built-in obsolescence run afoul of the law, and if so, what would the law do to correct it?

Economic theorists have explored whether, and under what conditions, designed obsolescence is an economically sensible strategy. ${ }^{262}$ It is not necessary to review that theoretical work in order to understand the problem of trying to regulate it. Consider the problem of fixing a standard for product durability. For products that provide a complex set of services, the economic durability of the product is determined less by its physical depreciation than by its functional obsolescence. Functional obsolescence can include anything from design changes (automobiles immediately come to mind) to operational features (as, for instance, with computer program "upgrades" or replacements). Regulating the physical attributes of such goods would be a pointless undertaking without creating some wider set of controls governing functional attributes. ${ }^{263}$ To make matters still more complicated, regulating the optimal physical and functional characteristics of the product leads inevitably to controlling the price of the product, which is the reverse of the same coin as far as consumer welfare is concerned. ${ }^{264} \mathrm{At}$ this point the regulatory venture begins to look like the folklore venture of the Sorcerer's Apprentice where the poor apprentice, having commanded a broomstick to carry his water for him, could not find a way to make him stop.

\section{CONCLUSION}

This Article betrays the ambivalence that is the hallmark of legal training: as the old joke goes, lawyers laid end-to-end might reach the moon but never a conclusion. Yet, firm conclusions are not easy to draw, as Zechariah Chafee discovered. In the seventy-five years since he first wrote on the subject, the issues have become more, not less, complicated. At the same time they have become more important, at least in the domain of intellectual property.

The new complications and the new importance are mostly the product of the digital age, where the emergence of computer software licensing has created, in practical effect, a kind of chattel servitude. Unsurprisingly this move has been extremely controversial, particu-

tions, and the production and marketing costs associated with them.

262 The primary focus has been whether the durability decision is different for a monopolist than for a competitor. For an overview, see Carlton and Perloff, Industrial Organization at 47697 (cited in note 206) (discussing how market structure affects durability, and the significance of whether monopolists rent or sell their goods).

263 Jeremy Bulow, An Economic Theory of Planned Obsolescence, 101 Q J Econ 729, 747 (1986) (discussing planned obsolescence and noting that it "is much more than a matter of durability; it is also and perhaps primarily about how often a firm will introduce a new product, and how compatible the new product will be with older versions").

264 See Schmalensee, 1 Bell J Econ \& Mgt Sci at 63-64 (cited in note 261). 
larly, though not exclusively, among academic commentators who see restrictive licensing as an attempt to expand the conventionally defined copyright and patent rights of digital producers. If these disputes have given new importance to the matter of personal property servitudes, however, they have also somewhat obscured the underlying issues by placing them in a framework commonly thought to be special and apart from common law property. I do not question that intellectual property is distinctive; what I have attempted to show is that the particular issues that are raised here are not. For example, the first sale doctrine that stands as the foremost obstacle to recognizing servitude-type restrictions in this area has been conventionally justified by reference to common law policies on restraints on alienability and restraints of trade. Yet few who invoke these policies have made any effort to examine them closely. For the most part they do not hold up well on such an examination. Fair use privileges might present more substantial grounds for refusing to enforce servitude-like restrictions on copyrighted material, but even here the basis for doing so turns out to be quite ambiguous. We noted, for instance, that in the case of restrictions on reverse engineering there is a clear tension between the fair use privilege on the one hand and the acknowledged right of owners to protect trade secrets.

The issue of personal property servitudes today is complicated in one respect that Chafee could not have foreseen - the possibility of incorporating use restrictions into the physical product itself. The emergence of digital rights management technology makes this a substantial alternative to contractual restrictions for digital products. Any effort to forbid contractual restrictions must therefore take into account the possibility that doing so will promote an alternative that would be at least as obnoxious and possibly more difficult to control. Those who wish for the legal prohibition of contractual restrictions on the use of digital products should be careful what they wish for. The result of such a prohibition is likely only to encourage "hard-wired" servitudes that will be, as a practical matter, even more difficult to control.

Whether servitudes take the form of contracts that run with the goods or are incorporated into product design, the legal question should not be addressed to some overarching issue of social or economic efficiency. We have markets to decide that issue. Some will no doubt dismiss the reference to market control as just economic dreaming. Everyone knows that markets don't work perfectly - they don't always yield fair or efficient results. There is a role for monitoring and correcting for market failures. All true, and completely irrelevant. It is not a question of whether markets always work. The problem of market imperfections or failures can always be addressed on its 
own terms. The question pertinent to property servitudes is simply where to set the baseline on entitlements. More precisely it is where to draw the baseline on personal property rights, for in fact a baseline has already been set for one class of property-land. For land servitudes, the set of legal restraints is quite limited because we assume that the imposition of use restrictions is a normal incident of property ownership. For various reasons, that assumption has proved to be controversial for personal property, including but not limited to intellectual property. Even acknowledging that personal property servitudes may run up against public policy concerns that have not historically applied to real property - the antitrust concerns come foremost to mind - this does not tell us anything about where the baseline should be set.

Mutatis mutandis, the same applies to intellectual property. Though intellectual property rights are more limited in scope than common law property rights, that fact by itself says nothing about the appropriate character of the limits. In any case, the assumption that intellectual property is distinctive turns out to be largely irrelevant to the question of servitude restrictions. When all is said and done about the differences between intellectual property and common law property, it is striking just how little those differences matter on the basic questions that are addressed here. The questions that have animated debate about property servitudes-such as the optimal standardization of property, principles of alienation, and issues of competition policy-do not greatly differ across property regimes. If I am right about this, more conversation is necessary between those who work in the traditional fields of common law property and those who specialize in intellectual property. In all events, those who work in either field must think more about the basic presuppositions of property and contract rights and whether the differences are as important as we have traditionally supposed. 


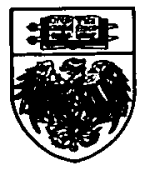

